\title{
Produçao Partilhada do Conhecimento: Uma experiência com as comunidades indígenas \\ Xavante e Karajá
}


Caio de Salvi Lazaneo

\section{Produçao Partilhada do Conhecimento: Uma experiência com as comunidades indígenas Xavante e Karajá}




\section{Produção Partilhada do Conhecimento: Uma experiência com as comunidades indígenas Xavante e Karajá}

Dissertação de mestrado apresentada com vistas à obtenção do título de mestre pelo Programa de Pós-Graduação em Ciências da Comunicação da Escola de Comunicações e Artes da Universidade de São Paulo. Área de concentração em Teoria e Pesquisa em Comunicação. Linha de Comunicação e ambiências em redes digitais.

Orientador: Prof. Dr. Sérgio Bairon Blanco Sant'Anna 


\section{Produção Partilhada do Conhecimento em Comunicação Digital: Universidade e Comunidade}

Dissertação de mestrado apresentada com vistas à obtenção do título de mestre pelo Programa de Pós-Graduação em Ciências da

Comunicação da Escola de Comunicações e Artes da Universidade de São Paulo. Área de concentração em Teoria e Pesquisa em Comunicação. Linha de Comunicação e ambiências em redes digitais.

DATA: _-l_L_

\section{BANCA EXAMINADORA}

Prof. Dr. Sérgio Bairon Blanco Sant’Anna - Orientador

Prof. Dr. - Convidado Interno

Prof. Dr. - Convidado Externo 
Dedico aos povos xavante, karajá e bororo.

$E$ aos seus infinitos saberes partilhados 
AGRADECIMENTO ESPECIAL

À Maria Angela, Vladimir, Bruna, Lívia e Mariana Pelo carinho, amor, cumplicidade e apoio incondicional 
AGRADECIMENTO ESPECIAL

Ao professor Sérgio Bairon por tudo o que há tanto vem fazendo, orientando e defendendo, não só no apoio desta e de tantas outras pesquisas e percursos, como também na experiência das inúmeras partilhas de conhecimento que proporciona e inspira 
A Divino Tserewahú, Paulinho Kadojeba e Juanahú Karajá, irmãos que conheci na trajetória desta pesquisa.

A minha família que soube sempre me confiar toda tranquilidade e estabilidade necessárias a qualquer pesquisa.

Às comunidades Xavante (Sangradouro - Tsö’rehipãri), Karajá (Fontoura - Btoiry) e Bororo (Meruri) pelo acolhimento, amizade e confiança.

A Aivone Carvalho Brandão, Sérgio Sato e Hyté, pela amizade, hospitalidade e pela inestimável colaboração.

Aos meus amigos-irmãos Jota Beck e Di Pannacci, parceiros e entusiastas de todos os projetos e ideias.. Sempre de prontidão, empunhando violões e câmeras, alegrando e registrando nossas trilhas..

A minha amiga Érica Nering, pelas incontáveis prosas, cafés e generosidade e pelo exemplo e inspiração constantes de seu trabalho.

A Arlete Petry e Eneus Trindade Barreto Filho pelas muitas contribuições ao presente trabalho durante a banca de qualificação.

Aos colegas de CEDIPP pela determinação, inspiração e relevância de suas pesquisas.

Aos funcionários da ECA, pela paciência, atenção e generosidade com que nos auxiliam cotidianamente nos diversos trâmites acadêmicos.

À Capes (Coordenação de Aperfeiçoamento de Pessoal de Nivel) pelo financiamento e incentivo à presente pesquisa. 
Seria legitimo definir o poder do saber por essa capacidade de transformar as incertezas da história em espaços legíveis. Mas é mais exato reconhecer nessas "estratégias" um tipo especifico de saber, aquele que sustenta e determina o poder de conquistar para si um lugar próprio. De modo semelhante, as estratégias militares ou cientificas sempre foram inauguradas graças à constituição de campos "próprios" (cidades autônomas, instituições "neutras" ou "independentes", laboratórios de pesquisas "desinteressadas" etc.). Noutras palavras, um poder é a preliminar deste saber, e não apenas o seu efeito ou atributo. Permite e comanda suas características. Ele se produz aí.

Michel de Certeau, "A Invenção do Cotidiano". 


\section{RESUMO}

A presente pesquisa propõe um estudo de uma trajetória de Produção Partilhada do Conhecimento, com foco em relações comunidade-universidade, mais especificamente em duas comunidades indígenas brasileiras, onde foram desenvolvidos trabalhos de campo: Aldeia Sangradouro (Tsö'rehipãri), da etnia xavante, Aldeia Fontoura (Btõiry), da etnia karajá, além da Escola de Comunicações e Artes (ECA) da Universidade de São Paulo (USP). Durante a pesquisa nessas comunidades, foram realizados produtos e registros audiovisuais, com dois interlocutores locais, Divino Tserewahú, entre os xavantes, e Juanahu Iny, entre os karajás, assim como a participação dos mesmos em atividades no contexto acadêmico.

Os diários de partilha trazem fotos dos diversos autores que participaram dos percursos e os relatos etnográficos das atividades com as distintas comunidades. Para a contextualização e problematização do processo de realização, partir-se-á dos conceitos de Produção Partilhada do Conhecimento, Cotidiano, Senso Comum e Hipermídia como aportes teóricos aptos à investigação de novas possibilidades de produção de conhecimento em Comunicação Digital.

Palavras-chave: Produção Partilhada do Conhecimento, Cotidiano, Senso Comum, Hipermídia, Comunicação Digital. 


\begin{abstract}
This research proposes a study of one trajectory of Shared Production of Knowledge, focusing on community-university relations, specifically in two Brazilian indigenous communities, which were developed fieldwork: Sangradouro village (Tsö'rehipãri), ethnicity Xavante, Fontoura village (Btõiry), ethnicity Karaja, and the School of Communication and Arts (ECA) at the University of São Paulo (USP). During the research in these communities were made products and audiovisual recordings, with two local interlocutors, Divino Tserewahú among the Xavante, and Juanahu Iny among Karajá, as well as their participation in activities in the academic context.

The daily of sharing brings photos from the various authors who participated of the routes and the ethnographic narration of the activities with the different communities. For contextualize and problematize the process of realization, we bring the concepts of Production Sharing Knowledge, Quotidian, Common Sense and Hypermedia as a theoretical framework suitable for investigating new possibilities of knowledge production in Digital Communication.
\end{abstract}

Key words: Shared Production of Knowledge, Quotidian, Common Sense, Hypermedia, Digital Communication 


\section{Sumário}

\begin{tabular}{lr} 
RESUMO & 21 \\
\hline
\end{tabular}

ÍNDICE DE FOTOS 14

\begin{tabular}{lr} 
ÍNDICE DE FIGURAS & 16 \\
\hline
\end{tabular}

\begin{tabular}{lr} 
INTRODUCCÃO & 17 \\
\hline
\end{tabular}

. O DIÁlOGO COMO PONTO DE PARTIDA: CEDIPP, MOMENTO INAUGURAL 17

. Partilhando objetos 19

. Multivíduo metodológico: Da Alteridade objetiva À Alteridade Conectiva. 20

CAPÍTULO I - INTERDISCIPLINARIDADE E HIPERMÍDIA 22

1.1 UMA COMUNIDADE DE COMUNICAÇÃO 22

1.2 ProduÇÃo PARTILHADA DO CONHECIMENTO: Do FILME À HIPERMÍDIA 24

1.2.1 “Rituaes e Festas Bororo”: Uma etnografia do EXótico 25

1.2.2 O ATOR INDÍGENA EM “SERRAS DA DESORdEM” 28

1.2.3 TrÂNSITOS DA APRESENTAÇÃO: “INDÍGENAS DIGITAIS, O FILME” 29

1.2.4 TRÂNSITOS DiALÓGICOS: DA REPRESENTAÇÃO À APRESENTAÇÃo 32

1.2.5 TSÕ'REHIPÃRI: REFLEXIVIDADE NO CINEMA XAVANTE

1.2.6 “Boé Eru Kurireu”, trânsitos dialógicos do Audiovisual À Hipermídia 37

CAPÍTULO II - COTIDIANO, SENSO COMUM E HIPERMÍDIA 40

2.1 SENSO COMUM E PRODUÇão DE CONHECIMENTO 40

$\begin{array}{ll}\text { 2.1.1 UMA COLHER CONECTIVA } & 45\end{array}$

2.1.2 TOMÕRE: O MÉTOdO VERTOV NO CINE-OLHO COTIDIANO XAVANTE 46

2.2 - O PROCESSO hipermidiático COMO Partilha do CONHECIMENTO 48

2.2.1 Táticas de Partilha, a CONSTRUÇão do diálogo 51

CAPÍTULO III: DIÁRIOS DE PARTILHAS

3.1 Partilha I: Aldeia Sangradouro - “Auwé Tsiwadzari: Curso de Formação de Cineastas INDÍGENAS"

3.2 Partilha II: Aldeia Fontoura - Ritual Hetohokã Karajá 76

3.3 Partilha III - Ritual Wapté MÑoño Xavante 95

3.4. Partilha IV: Edição do filme Karajá na ECA - USP 133

CONSIDERAC ÕES FINAIS $\quad 145$

UM TRAJETÓRIA DO EMPÍRICO AO CONCEITUAL $\quad 145$

REFERÊNCIAS BIBLIOGRÁFICAS 


\section{ÍNDICE DE FOTOS}

Foto1 Momento de diálogo entre Caio Lazaneo e o pajé Karajá da Aldeia Fontoura

Foto2 Divino Teserwahú e Natal Anhahö'a participam de uma aula na pós graduação em Ciências da Comunicação da ECA-USP.

Foto3 En.quadra.to.men - Divino Tserewahú e Caio Lazaneo durante o Ritual Wapté Mñoño na Aldeia Xavante Sangradouro

Foto4 Encontro dos Indígenas kuikuro e kalapalo com professores de audiovisual e estudantes de medicina.

Foto5 Koluta, batuca e os trutas

Foto6 Rangu Kalapalo registrando cenas para o filme sobre a alimentação xavante

Foto7 Diálogo entre os participantes da oficinas sobre o material capturado

Foto8 Xavantes de Öwawe x Participantes da oficina. Vôlei muti-étnico

Foto9 Improviso no pandeiro e violão para agradecer a hospitalidade da Aldeia Öwawe

Foto10 Jovens da aldeia Öwawe divertindo-se com brincadeiras e competições inventadas na hora no Rio Cristalina

Foto11 O bororo Paulinho Ecerae Kadojeba, ao fundo, "empunha" sua câmera e filma - além da câmera que fotografa - o professor de artesanato Casimiro Weté. No primeiro plano, o xavante Pascoalino Tseremadzawe'Raiwi'a também o filma

Foto12 José Carlos Tsipatsé dá de presente uma pulseira de imbira

Foto13 José Carlos Tsipatsé, Daiane Bakarae, Daves Ocereu e Pascoalino Tseremadzawe'Raiwi'a, trabalham na edição do filme sobre o artesanato xavante

Foto14 Viola Kalapalo filma Valeriano Rãiwi’a Werehité durante conversa após exibição de filmes

Foto15 Padre Luíz Leal é filmado por Kaiauta Kalapalo e fotografado por Rangu Kalapalo Foto16 Plateia da aldeia assiste a projeção dos filmes

Foto17 Grupos falam sobre o processo de realização dos filmes

Foto18 Alguns participantes do "A'uwé Tsiwadzari: Curso de Formação de Cineastas Indígenas", Aldeia Sangradouro

Foto19 Cruz no pátio central da Aldeia Sangradouro

Foto20 José Carlos Tsipatsé (de costas no primeiro plano) segura seu filho no colo e assiste a seu próprio filme

Foto21 Vista da aldeia Sangradouro, Tsö'rehipãri

Foto22 Juanahú Karajá, Divino Tserewahú e Caio Lazaneo a caminho da Aldeia Santa Isabel

Foto23 Juanahú Karajá filma o time de futebol feminino da Aldeia Santa Isabel

Foto24 Aruanãs na noite da Aldeia Fontoura

Foto25 Lado externo da casa de saúde da aldeia. A população karajá assiste à projeção das filmagens do dia 
Foto26 Paulinho Kadojeba filma Kumairú Karajá mimetizando um macaco

Foto27 Paulinho Kadojeba ensina noções de filmagem a Mairú Karajá durante a busca do cipó Hatyriry

Foto28 Paulinho Kadojeba ensina Mairú Karajá

Foto29 Caio Lazaneo filma cipó Hatyriry sendo retirado do alto das árvores

Foto30 transporte do cipó Hatyriry para a Aldeia Fontoura

Foto31 Caio Lazaneo e Divino Tserewahú durante a gravação da pescaria

Foto32 Juanahú Karajá filma a pescaria

Foto33 Juanahú Karajá e Paulinho Kadojeba filmam o cacique Wajuria às margens do rio Araguaia

Foto34 Divino Tserewahú, tomõre (olho de câmera) e o rio Araguaia

Foto35 Juanahú filma o pôr-do-sol no rio Araguaia

Foto36 Arrebol no rio Araguaia

Foto37 Silhuetas araguaias: Diálogo da equipe com Koxini às margens do rio Araguaia

Foto38 Reflexividade: Projeção das gravações diárias para a comunidade

Foto39 Koxini e o cacique Wajuria da Aldeia Fontoura assistem o material bruto do ritual Hetohokã

Foto40 Caio Lazaneo e Divino Tserewahú recebem a pintura karajá

Foto41 Equipe Cedipp, aldeia Fontoura

Foto42 Caio Lazaneo e o "chará" Caio no colo de sua mãe

Foto43 Crianças xavantes acompanham os registros do Wapté feitos por Di Pannacci

Foto44 Caio Lazaneo filma Divino Tserewahú como noni

Foto45 Reencontro: Natal Anhahö’a, Caio Lazaneo e Divino Tserewahú em Tsö’rehipãri

Foto46 "Essa eu que matei"

Foto47 Eliseu Tserenhomware, Di Pannacci, Sérgio Waiadzatsé, Fábio Tsitobrowe, José Marinoni Tsõpré, Caio Lazaneo, Beto Tseredze Wa'u'é, Natal Anhahö'a e Divino Tserewahú

Foto48 Chegada da caça à aldeia e defumação nos girais

Foto49 Adalbert Heide mostra seus filmes sobre os xavantes

Foto50 José Carlos Tsipatsé filma preparo de baktés

Foto51 Noni vestindo a máscara

Foto52 Corrida dos waptés

Foto53 Corrida dos waptés.

Foto54 Divino filma a saída para a clareira para o preparo das máscaras dos waptés

Foto55 Preparação das máscaras dos waptés na clareira

Foto56 Fábio Tsitobrowe tingindo de urucum a máscara de wapté

Foto57 Corrida dos pahâiri'wá

Foto58 Corrida dos waptés 
Foto59 Natal Anhahö’a, Caio Lazaneo e Eliseu Tserenhowamre, na dança dos padrinhos Etepa

Foto60 Adalbert Heide filma os baktés com alimentos

Foto61 Preparação do tébé

Foto62 colocação da máscara no tébé

Foto63 tébes (com as "varinhas") e noni (agachado) mais velhos ensinam os mais novos

Foto64 Tébés mais velhos terminam de retirar a máscara dos tébés mais novos

Foto65 Tensão dialógica: o xavante Divino Tserewahú e o salesiano Adalbert Heide registram o ritual

Foto66 O cacique Alexandre Tsereptsé, na clareira, ensina aos novos pahâiri'wá a dança do sol

Foto67 Todas as gerações dos pahâiri'wá ensaiam a dança do sol

Foto68 Os novos pahâiri'wá ensaiam a dança do sol

Foto69 Os dois jovens pahâiri'wá fazem a dança do sol

Foto70 Padrinhos correm para levar as máscaras às casas das famílias dos waptés

Foto71 Novo tempo: Juanahú, Paulinho e Divino em frente a praça do relógio da Universidade de São Paulo

Foto72 Juanahú, Paulinho e Divino na recepção do Oca hostel

Foto73 Juanahú e Paulinho decupam o material bruto do Hetohokã

Foto74 Divino, Paulinho e Juanahú em frente à FFLCH (Faculdade de Filosofia Letras e Ciências Humanas) da USP

Foto75 Caio Lazaneo, Divino Tsrewahú e Paulinho Kadojeba que fotografa, pelo celular, Juanahú fotografando

Foto76 Caio, Juanahú e Divino trabalham na edição do filme karajá

Foto77 Divino Tserewahú, Paulinho Kadojeba, Juanahú Karajá e Caio Lazaneo na ECAUSP

Foto78 Divino, Juanahú e Paulinho embarcando de volta para suas aldeias

\section{ÍNDICE DE FIGURAS}

Fig. 01 Índio bororo de perfil

Fig. 02 Índio bororo numa perspectiva frontal

Fig. 03 Ao final do filme o letreiro sugere: “Tínhamos ali a sensação dos remotos tempos do descobrimento 
Fig.04 Chacina na aldeia

Fig.05 Fuga de Carapirú com seu filho

Fig.06 Carapirú vê sua histório em um jornal

Fig. 07 jaborandy@indiosonline.org.br fala sobre o que pensa ser um indígena digital

Fig. 08 nhenety@indiosonline.org.br compara o papel do arco ao da internet

Fig. 09 alex.makuxi@indiosonline.org.br relata ter conhecidos outras etnias através da internet

Fig. 10 A aldeia Sangradouro reunida para assistir o filme Tsö rehipãri "ainda inacabado"

Fig. 11 A aldeia Sangradouro vista de cima. Divino faz uma fusão da imagem, do mesmo plano, do filme de 1949 com o seu em 2009

Fig. 12 Crianças xavantes assistem a versão inacabada de Tsö rehipãri. Cena que faz parte do começo do "filme finalizado"

Fig. 13 Hipermídia "Boé Eru Kurireu", ambiente digital que apresenta um filme de um bororo, montado por um xavante, e uma dissertação de mestrado 


\section{Introdução}

\section{O diálogo como ponto de partida: CEDIPP, momento inaugural}

A presente pesquisa iniciou-se, por ventura, em um momento particularmente singular no tocante ao debate sobre caminhos para uma Partilha da Produção do Conhecimento em Comunicação Digital, com o foco na hipermídia enquanto expressividade apta a lidar com os desafios de um processo de inter-relação de comunidades, sublinhando a ênfase dialógica no contexto universidade-comunidade.

Momento este inaugural da formação de um grupo de pesquisa nomeado CEDIPP (Centro de Comunicação Digital e Pesquisa Partilhada), coordenado pelo prof. Dr. Sérgio Bairon, orientador desta pesquisa, na Escola de Comunicações e Artes da Universidade de São Paulo. Felizmente, pude participar do momento embrionário do grupo e a presente pesquisa constitui um dos primeiros produtos acadêmicos resultantes desse processo ${ }^{1}$.

O primeiro diálogo, ou possibilidade de partilha a inspirar este projeto, se deu no contato com a dissertação de mestrado - em Comunicação e Semiótica na PUC-SP - "A tensão dialógica entre auto e hetero-representação no Funeral Bororo na Terra Indígena de Meruri” (2010) realizada pelo pesquisador Sérgio Sato. Pesquisa esta também orientada pelo prof. Dr. Sérgio Bairon e que lidou com algumas comunidades indígenas (bororo e xavante) na proposição de produtos audiovisuais e hipermidiáticos expressando uma possibilidade de diálogo universidadecomunidade. Desde o primeiro momento em que conheci o produto - ainda quando cursava em 2010, como ouvinte, a disciplina "Teorias da Produção do Conhecimento em Hipermídia", na ECA - USP - a pesquisa chamara a atenção por diversos aspectos, como a interdisciplinaridade presente no diálogo entre comunicação e antropologia, a produção de conhecimento expressa no diálogo universidade-comunidade, a experiência estética na proposição hipermidiática que relacionava um produto acadêmico e uma produção "não-científica", além da evidente postura ético-epistemológica em um método que consistia em tecer uma crítica conjunta a uma determinada forma de representação. De imediato, passei a me comunicar, com grande prazer, com Sérgio Sato e a conhecer o trabalho desenvolvido nessas comunidades e também no Museu das Culturas Dom Bosco, sob coordenação da prof. ${ }^{a}$ Dr. ${ }^{a}$ Aivone Carvalho - tanto Sérgio quanto Aivone tem, através de sua amizade e generosidade, uma contribuição inestimável ao meu percurso de pesquisa.

Como em tantas outras pesquisas, a despeito da persistência e recorrência à imagem do pesquisador como alguém solitário a trabalhar em sua torre de marfim (em um imaginário que permeia o contexto da "grande Ciência") estamos aqui calcados em um momento

1 A dissertação de mestrado "Ciência em Hipermídia: Tramas digitais na produção do conhecimento" (2011), da pesquisadora Érica Nering, constitui, propriamente, a primeira pesquisa no eixo temático "Hipermídia e Produção de Conhecimento Científico" do CEDIPP. 
inaugural de diálogos. A partir do contato com interlocutores das comunidades indígenas, mais especificamente Divino Tserewahú, entre os xavantes, Paulinho Kadojeba, entre os bororos e Juanahú Karajá, entre os karajás, passamos a praticar efetivamente atividades de Produção Partilhada de Conhecimento através de intercâmbios constantes entre essas comunidades e a Escola de Comunicações e Artes da Universidade de São Paulo. Propostas como a realização de oficinas e registros de rituais - feitas por uma equipe plural contando com os interlocutores das comunidades indígenas e, além de mim (enquanto interlocutor de uma pesquisa acadêmica), amigos convidados a participar das atividades -, a participação dos interlocutores em aulas na pós graduação privilegiando a partilha de experiências e saberes e a montagem de produtos audiovisuais utilizando a infraestrutura da universidade, também fizeram parte, propriamente, deste momento inaugural do nosso centro de pesquisa.

As fotografias que acompanham sobretudo os diários de partilha (ou os diários de partilha que acompanham as fotografias), enquanto testemunhas oculares, engendram possibilidades de reconfiguração dos sujeitos. Quais são as testemunhas e quais são os sujeitos? Quem fotografa e quem é fotografado? O uso das diversas fotografias dos vários fotógrafos (Caio Lazaneo, Di Pannacci, Divino Tserewahú, Érica Néring, Jota Beck, Juanahú Karajá, Luíz Eduardo Silva, Kaiauta Kalapalo, Paulinho Kadojeba, Sérgio Bairon) que participaram dos percursos, expressam e antecipam, assim, o conceito da produção partilhada em que, por partilha, compreendemos, neste sentido, também as táticas dialógicas imagéticas.

Acreditamos que a comunicação, enquanto ação partilhada, múltipla de sentidos, pode sublinhar um processo de produção de conhecimento quando inaugural de um lugar de partilha, um habitar de diálogos. Destarte é este, fundamentalmente, o ponto de partida e, quiçá, o de chegada a esboçar um ininterrupto processo em que os fios de uma trama de saberes plurais hão de ser sempre tecidos sob uma abertura dialógica.

\section{Partilhando objetos}

A delimitação do objeto, nos parece, é um desafio perene ao pesquisador das Ciências da Comunicação e nos permite, inclusive, o questionamento sobre o que não poderia se constituir, propriamente, um objeto a ser estudado por essa área, ainda que esta seja, como toda regionalidade científica, permeada por amarras institucionais

Nesta pesquisa, essa questão constitui um jogo particular em que a definição metodológica de "objeto" é alvo de uma constante reformulação. Destarte, procuramos empreender um processo no qual fosse possível elaborar estratégias de desenvolvimento de pesquisa com uma comunidade em que esta, não mais atuando enquanto "objeto", participe como sujeito da partilha do processo de produção de conhecimento, seja através de propostas que envolvam um grande número de participantes das respectivas comunidades ou, pormenorizadamente, através do trabalho específico de alguns de seus interlocutores. Essa sugestão expressa uma 
"partilha fragmentária", no sentido de uma "cisão" - mas que é, entretanto, não disjuntiva do substantivo "objeto", ao ponto que ao esfarelarem-se, seus múltiplos pedaços como um caleidoscópico reflexivo, não mais podem "representar", através do (re)conhecimento de um sujeito, uma reordenação e compreensão do mundo, senão apenas expressar o singular diálogo do qual são também agentes, sujeitos, interlocutores, tanto de uma comunidade quanto de uma universidade.

Nos diz Bakhtin (2011, p.4), subentendendo autor e personagem no contexto de uma filosofia geral estética, que "o que na vida, na cognição e no ato chamamos de objeto definido só adquire determinidade na nossa relação com ele: é nossa relação que define o objeto e sua estrutura e não o contrário". É necessário nos perdermos, "nós mesmos", sujeitos do cogito, e, consequentemente, "a determinidade estável do mundo" (p.4), para reinaugurar um sujeito que atua como interlocutor de um diálogo - e não mais um determinante do objeto -, ao domínio de um conceitual aleatório. Interessa-nos, neste caso, a indeterminabilidade do objeto, algo próximo da sugestão fenomenológica de que "nunca jogo, mas sou jogado".

O sujeito conceitual, em uma proposição da Produção Partilhada, configura-se, ao mesmo tempo, como objeto e sujeito da pesquisa-diálogo. Nestas tramas conceituais, o lugar acadêmico institucional, visto como "origem" de um saber hegemônico, é posto como objeto de partilha horizontalmente em relação à saberes do senso comum sugerindo, deste modo, possibilidades de trocas estético-conceituais com comunidades em que as formas da produção do conhecimento operam de outro modo. Ocorre disto, a reconfiguração do sujeito, pesquisador, para a função de interlocutor - também objeto da comunidade-sujeito - a exercitar a mediação e o alicerce comunicativo na produção do conhecimento. 


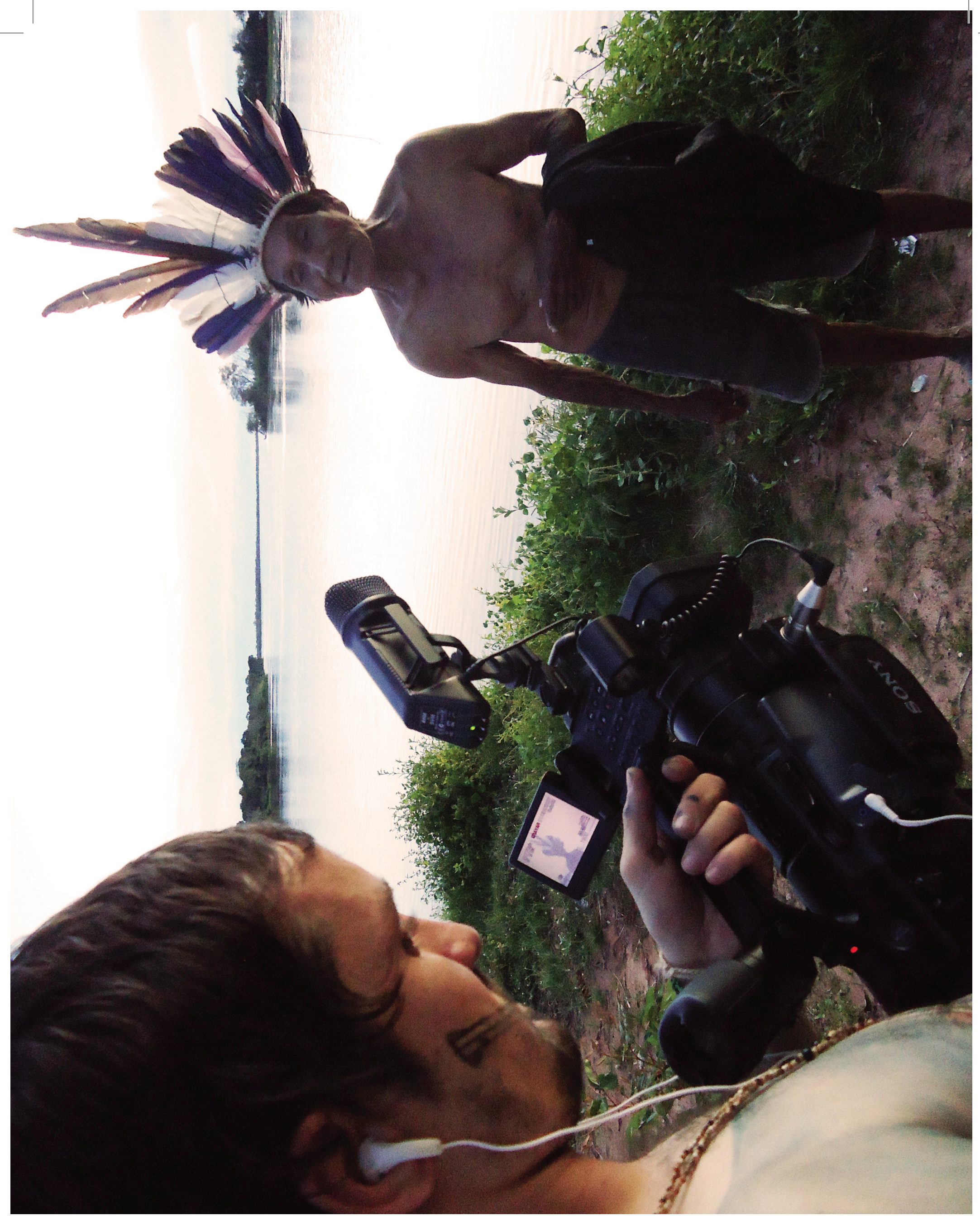

Foto1. Momento de diálogo entre Caio Lazaneo e o pajé Karajá da Aldeia Fontoura. Reconfiguração do pesquisador como objeto da comunidade-sujeito. (foto: Divino Tserewahú) 


\section{Multivíduo metodológico: Da alteridade objetiva à alteridade conectiva.}

O estabelecimento de uma estrutura hierárquica entre ciência e senso comum, sobretudo a partir do século XVIII, fora determinante para o solapamento, em larga escala, da partilha como um horizonte possível na produção do conhecimento presente no encontro de comunidades (científica e outras tantas além da universidade). Uma lógica que subentende o lugar próprio da cientificidade como o portador do "saber" e, deste modo, os "saberes locais" (Geertz, 1997; Medina, Greco, 1999), comunitários, tendem a ser esquematizados, metodologicamente, enquanto objetos que possibilitam o acesso a um saber outro, operando sob uma outra lógica taxionômica e em um diferente - e distanciador - nível de compreensão. Nos diz Cremilda Medina que

o esforço científico é obsessivo pela normatização, porque ou corre atrás do poder de controlar, ou se inebria pelo progresso. A ideologia desenvolvimentista de ampla difusão nos últimos dois séculos entroniza o papel da ciência. Prometem-se, em larga escala, garantias evolucionistas: estamos indo para melhor, graças às conquistas científico tecnológicas (1999, p.33)

aspecto este que evidencia uma hierarquia nas estruturas de poder que atuam na produção de conhecimento, salientado na obra de diversos pensadores.

Interessa-nos a investigação e a proposição de possibilidades metodológicas, em Ciências da Comunicação, que permitam um momento reinaugural. Compreendemos, neste caminho, que faz-se necessário cada vez mais sugestões, reformulações e reflexões sobre conceitos que possam questionar paradigmas já gastos de compreensão de mundo. Uma perspectiva aponta para um caminho em que o "eu", sujeito privilegiado, passe a esboçar um plural "eus" (Canevacci, 2012), compreensão que sugere a superação de um indivíduo, indivisível, para o múltiplo, multivíduo: Um “eu multivíduo. O meu eus" (p. 77). O “eus" pode também esboçar, na nossa compreensão, um potencial agente dialógico, sujeito da partilha, em que não mais pese um antigo alicerce antropológico de uma alteridade disjuntivo-objetiva, mas uma interrelação entre alteridades conectivas. Tramas dialógicas em que o “eus”, multvíduo da metrópole comunicacional, possibilita uma relação transitiva em interlocução entre multvíduos. Deste modo, no horizonte da partilha, não mais nos interessa esboçar uma compreensão individual portanto indivisível - mas dialógica, multividual, transitiva. Uma trajetória em que a própria Comunicação somente faz sentido enquanto ação partilhada. Entretanto, de que modo seria possível uma proposição metodológica de pesquisa a partir de um multivíduo? "O nativo desnativizado", "o outro des-nativizado" (p. 79), subverte sua inanição museográfica e estabelece conexões em uma constelação de alteridades. Assim, proposições como a realização de um filme sobre um ritual da etnia karajá, a partir de uma equipe sincrética da qual faça parte karajás, xavantes, bororos e pesquisadores acadêmicos, esboça um multividual caminhar metodológico. 
Neste caminho, a possibilidade hipermidiática, enquanto uma superação da escritura rígida e formal de um método que eleva ao "autor" - indivíduo - o protagonismo de um único, "legítimo" e "indivisível" texto, apresenta-se como uma adequada proposta teóricometodológico. Defendemos que diferentes matrizes, como a verbal, sonora e visual (Bairon, 2007, Santaella, 2005) possam habitar um mesmo produto acadêmico-comunitário. A expressividade estética, através da Hipermídia, apresenta-se como uma possibilidade para o desenvolvimento do conceito dialógico da Produção Partilhada, enquanto habitar do encontro das diferentes matrizes e comunidades.

\section{Capítulo I - Interdisciplinaridade e Hipermídia}

\subsection{Uma comunidade de comunicação}

Não se trata, em nível de produção de conhecimento, de uma simples ruptura com a tradição metodológica que até os dias de hoje está presente no meio científico, mas de construirmos uma interlocução produtiva entre as expressividades estéticas para proposta interdisciplinares, tendo como meio tecnológico não mais o livro em sua versão de códice, mas ambientes digitais.

Sérgio Bairon (2002, p.123)

Geertz (1997) nos chama a atenção para uma "mistura de gêneros", entre as ciências sociais e as humanas, fruto de uma mudança cultual, que culminaria assim em uma "reconfiguração do pensamento social", um processo de adaptação "a uma situação ao mesmo tempo fluida, plural, descentralizada, e inerradicavelmente desorganizada" (p.35). A recorrência das ciências sociais às analogias explicativas das Humanidades seria, segundo ele, uma "evidência da desestabilização dos gêneros", o que possibilitaria, desta forma, uma abertura hermenêutica. Abertura esta a trânsitos disciplinares de conectividades temáticas e locativas.

Se tudo isso está tornando as ciências sociais menos científicas, ou as ciências humanas mais científicas (ou, como creio, mudando nossa opinião, que nunca foi mesmo muito estável sobre o que é, ou não, ciência) não está muito claro, e talvez nem seja lá muito importante. (ibid., p.17)

Entretanto, para o autor, o fato importante é que essa desestabilização está alterando as características de ambas as ciências e criando novas inquietações em que "não é só a teoria ou a metodologia, ou a problemática que se alteram, mas o próprio objetivo do empreendimento". (id., p.17)

Fruto constante de uma mistura de gêneros, a comunicação encontra-se inserida neste processo. Neste caminho, salientamos alguns dos pontos reticulares que tangenciaram, em 
maior ou menos grau, a presente dissertação. A trajetória interdisciplinar iniciou-se, de certo modo - mas não necessariamente nesta ordem -, no seio de um contexto muito peculiar e caro à Antropologia Cultural e a Etnografia: A produção de conhecimento na relação com distantes comunidades. Paralelamente, neste percurso, buscou-se a interlocução com um método também muito peculiar à Antropologia Visual: A produção de conhecimento através da proposição de produtos audiovisuais com comunidades específicas. Todavia, a inspiração na História da Cultura, enquanto regionalidade científica que sublinhou a importância da investigação imagética no interior da trajetória de pesquisa e do produto dela decorrente, não poderia deixar de ser evidente. Por fim, a Comunicação Digital, enquanto regionalidade "específica" de área da presente pesquisa, nos apresenta aqui como uma sustentação reticular, lugar de uma interface dialógica. Cabe também a reflexão sobre a hipótese de que nenhuma das referidas áreas, de forma isolada, seria talvez suficiente para os desafios em questão. E, tampouco, a interlocução interdisciplinar não visa esgotar o fenômeno, pelo contrário e de forma hermenêutica, abri-lo ainda mais à perguntas. Não sustentamos uma panaceia metodológica que, por meio da interdisciplinaridade, "corrigiria" os excessos de si mesmo criados por uma ciência departamentizada, mas sublinhamos, de acordo com Bairon - compreendendo a Hipermídia como a expressão de uma possibilidade de encontro interdisciplinar - que

o que deve predominar no âmbito educacional inspirado por esses temas é uma reformulação das práticas de ensino, orientada não ao 'restabelecimento' ou mesmo à criação de uma realidade supostamente ideal, mas muito mais ao estabelecimento de um conjunto de práticas pensado e planejado a partir da criação de uma comunidade de comunicação ${ }^{2}$ que resulte do encontro dessas práticas com uma imersão teórica sobre a própria noção de linguagem no meio educacional. (ibid., 2002, p. 124)

Destarte, o desafio de uma proposição interdisciplinar de conhecimento nos parece um caminho sensato não só enquanto expresse uma comunidade de diálogos - comunicações científicos, bem como, para além disso, ofereça subsídios teórico-metodológicos na lide com pesquisas que dialoguem não só entre campos de saberes institucionalizados (departamentos acadêmicos, regionalidades científicas, grupos de pesquisa, etc.) como também entre diferentes campos de saberes (saber científico e senso comum). Ainda segundo Bairon,

a comunicação atual pressupõe as relações dialógicas como o centro de usinas midiáticas de vias múltiplas. Os desafios para sua compreensão são, sobretudo, de fundamento, ou seja, precisamos encontrar dimensões conceituais que sustentem a sua compreensão. (ibid., p. 19)

Neste sentido, os desafios hermenêuticos também sugerem a criação de diálogos, em 2 Grifo meu. 
"vias múltiplas", que ofereçam um alicerce - fundamento - para constantes (re)formulações conceituais.

Assim defendemos que, sobretudo na Comunicação Digital, faz-se sempre necessária uma constante abertura epistemológica, permeada pelos fluxos dialógicos entre disciplinas e saberes.

\subsection{Produção partilhada do conhecimento: Do filme à hipermídia ${ }^{3}$}

Desde que o anseio pelo desvelamento de tudo que se apresentava como estranho fez do início do cinema uma espécie de "irmão gêmeo" da etnografia, o mundo das experiências audiovisuais demonstrou, intencionalmente ou não, a palinódia entre cotidiano e compreensão não verbal do mundo. Nesse percurso, que compreende algumas etapas do desenvolvimento do do filme etnográfico, interessa-nos sublinhar experiências/produtos no universo do registro fílmico e hipermidiático de diferentes etnias brasileiras, como suporte a uma discussão teóricometodológica sobre possibilidades de Produção Partilhada do Conhecimento.

Primeiro, na perspectiva de registros realizados por não índigenas, analisamos os filmes "Rituaes e Festas Bororos" (1916) do Major Luiz Thomas Reis, "Serras da Desordem" (2006) do cineasta Andrea Tonnacci, e "Indígenas Digitais, o filme" (2010), de Sebastian Gerlic, disponível em plataforma online.

Num segundo momento, analisamos o filme "TSÕ'REHIPÃRI" (2009), do cineasta xavante Divino Tserewahú, no qual a ênfase dialógica e a reflexividade são essenciais à construção da narrativa. Um quinto produto analisado é a hipermídia "Boé Eru Kurireu" (A Grande Tradição Bororo), um produto que foge da categoria fílmica dialogando com o hipertexto e recursos não-lineares, num ambiente digital que hibridiza o documentário homônimo do bororo Paulinho Ecerae Kadojeba e a pesquisa de Sergio Sato (2009) sobre a tensão dialógica entre auto e hetero-representação no contexto do ritual fúnebre bororo, estruturadas no conceito de reticularidade filmica.

Nesse caminho, apontamos divergências conceituais e situamos os diferentes produtos no embate entre representação e apresentação a partir de realizações audiovisuais/hipermidiáticas produzidas de distintas formas de autoria: a primeira, no contexto da representação, a autoria se situa em exterioridade em relação à comunidade indígena; as segunda e terceira modalidades, no contexto da apresentação, ou o autor é um interlocutor da própria comunidade ou através de um processo de partilha do conhecimento, a hipermídia (Bairon, 2010) promove uma possibilidade de encontro entre o(s) interlocutor(es) de uma comunidade e o(s) interlocutor(es) de uma pesquisa acadêmica.

3 O artigo "Produção partilhada do conhecimento: Do filme à hipermídia", de autoria de Caio Lazaneo e Sérgio Bairon, fora submetido como artigo, ao DT "Estudos Interdisciplinares”, GP "Comunicação, Mídias e

Liberdade de Expressão”, do XXXV Congresso Brasileiro de Ciências da Comunicação. 


\subsection{1 "Rituaes e Festas Bororo": Uma etnografia do exótico}

A propagação das tecnologias comunicativas, intensificadas pelo advento da eletricidade (como pode ser observado no caso da pretendida expansão do território através da consequente expansão das linhas telegráficas promovidas pela Comissão Rondon), resultou na diluição do hic et nunc e numa possibilidade de "reprodução técnica da paisagem", compreendida por Di Felice como um produto de um habitar exotópico (2009, p. 119). Por exotópico compreende-se um habitar em relação com um território múltiplo em relação externa ao sujeito.

O major Luiz Thomaz Reis é reconhecido pelos diversos registros fílmicos e fotográficos realizados ao longo de sua chefia da Secção de Photographia e de Cinematographia da Comissão Rondon". Seu filme "Rituaes e Festas Bororo", de 1917, é um dos primeiros registros etnográficos dos bororos realizados por não indígenas. O contexto de sua realização, num período de profusão do advento da eletricidade, nos remete a esse caráter de exotopia (Di Felice, 2009). Os registros realizados pelo Major Thomaz Reis proporcionavam "um efeito dilatador e multiplicativo do espaço" (p. 119), até então comprimido em um imaginário tipográfico do relato textual dos viajantes. Como nos lembra Fernando de Tacca (2002), "Rituaes e Festas Bororo" foi exibido em 1918, por meio de patrocínio da rede National Geographic Society, no Carneggie Hall em Nova Iorque, ocasião na qual ocorreu a visita do próprio major e cineasta (p. 200). Esta visita "foi nomeada pelo governo brasileiro "Expedição científica RooseveltRondon"5. Um exercício etnográfico que recebia o aval oficial do governo brasileiro como uma premissa científica além de "civilizatória", da qual também dependia Rondon para o apoio à expedição.

Numa perspectiva "exotópica", portanto, "mecânica e externa de ser" (Di Felice, 2009, p.122) e exótica, representando institucionalmente o olhar do estado sobre a figura do "selvagem" incrustrado nos confins longínquos do país, essa forma comunicativa estabelece-se numa relação de frontalidade. Uma etnografia que privilegia uma dinâmica frontal e externa ao seu "objeto" e que utiliza no cerne de sua metodologia essa distinção, aponta-nos para uma mediação em que não se evidencia o diálogo no processo de construção do filme. Diálogo que se torna possível no contexto da construção partilhada de hipermídias, como já defendemos outrora (Bairon, 2000). O filme enviesa por uma representação na qual

as tomadas dos nativos são feitas conforme o estilo antropométrico vigente na época - de estreita derivação da antropologia criminal - de modo que o sujeito 'outro' é filmado antes de frente e, depois, de perfil. O objetivo

4 A Comissão Rondon, estabelecida e chefiada pelo Marechal Candido Rondon a partir de 1907, tinha entre seus objetivos expandir a rede telegráfica nacional por locais de difícil acesso e até então pouco explorados pelos não índios. Deste modo, e parte desse projeto integracionista, procurou estabelecer o contato interétnico com diferentes etnias visando integrá-las a um modelo de desenvolvimento positivista da sociedade através da tentativa de transformação do "selvagem" em "civilizado" (TACCA: 2002).

5 Sobre a visita do ex-presidente Theodor Roosevelt à Comissão Rondon ver "Rituaes e Festas Bororo: a construção da imagem do índio como "selvagem" na Comissão Rondon" de Fernando de Tacca (2002) 


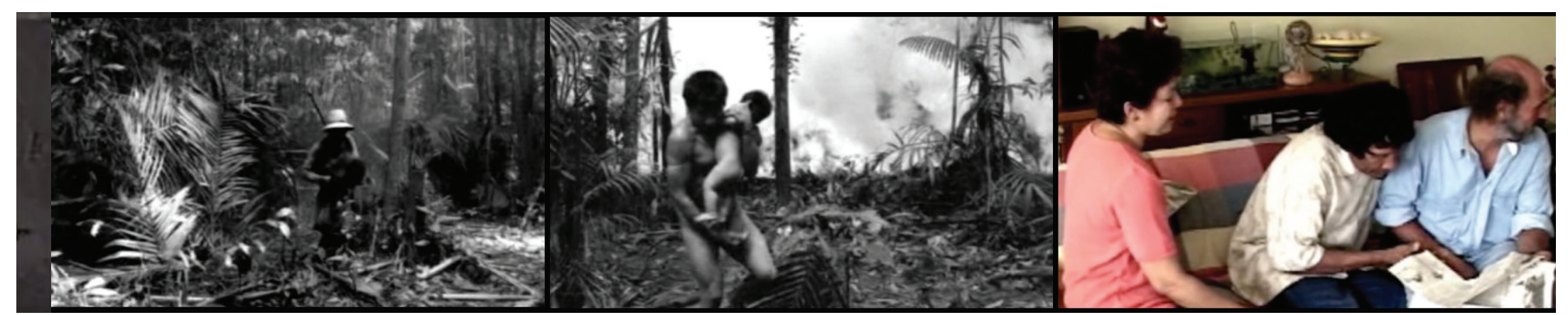

Fig. 04 Chacina na aldeia

Fig. 05 Fuga de Carapirú com seu filho

Fig. 06 Carapirú vê sua história num jornal

num exercício audiovisual, classificado por ele próprio como um "documento" (em lugar de "documentário"), aludindo às reivindicações dos índios "Canela" (em relação à demarcação de terras e conflitos fundiários) presentes no filme (Satiko, Sztutman, Zea, 2007). No filme Tonacci reencena a diáspora do índio Carapiru (da etnia Awá Guajá) que, após escapar de uma chacina que vitima sua aldeia (quando separa-se de seu seu filho), passa dez anos a vagar pelas serras amazônicas maranhenses até o sertão bahiano.

A proposta fílmica do diretor, que também leva 10 anos para ser realizada, era a de que o próprio Carapiru (contando com o seu consentimento), entre outros personagens que tivessem vivenciado os fatos, atuassem na reconstrução das narrativas (no caso de Carapirú, inclusive, nas cenas da chacina e da separação de seu filho). O resultado é uma desordem-sincrética, que questiona o lugar comum destinado na grande maioria dos casos aos atores indígenas nas produções audiovisuais realizadas por não índigenas. No filme Carapirú é protagonista de sua própria história na qual, em conjunção com a poética narrativa sugerida pelo diretor, atua desordenadamente nos propondo um sincretismo audiovisual. Entretanto, em "Serras da Desordem" e nos outros filmes de temática indígena de Tonacci encontramos uma autoria externa ao índio, operando como uma espécie de porta-voz que reafirma as diferenças e busca através dela estabelecer um processo reflexivo. Podemos interpretar essa compreensão nas palavras do próprio Tonacci, em resposta a uma pergunta sobre a falta de legendas em português nas falas indígenas de seu filme:

O filme é, na verdade, feito para nós, não é feito para eles, é feito para branco ver. E eu falo da gente. Eu não falo dos índios. Eu falo de um sentimento humano nosso, eles são os atores do filme. Existe um conhecimento anterior que é o que me permitiu chegar perto, e que fez com que a imagem pudesse

transmitir tudo isso. Mas, na verdade, estou narrando uma leitura nossa da situação deles, que pensando bem não é muito diferente da nossa. No essencial

a incomunicabilidade não ocorre." (Tonacci in Revista do IEB, n45 set.2007, entrevista concedida à Satiko, Sztutman, Zea). 
Evidenciamos aqui uma comunicação que a despeito da proposta sincrética, delimita e opta por um espaço específico de representação. A condição indígena, representada por meio da história de Carapirú, funciona como uma crítica ao olhar do não indígena.

Ao final do filme o letreiro nos avisa textualmente: "Os personagens principais deste filme foram interpretados pelas mesmas pessoas que viveram os fatos narrados". Como uma espécie de "reordenação" da "desordem", Tonacci esclarece sua estratégia narrativa com a ênfase no aspecto "ficcional" e no caráter documental, num espaço híbrido, onde habitam interpretações e reinterpretações de uma mesma história.

\subsubsection{Trânsitos da apresentação: "Indígenas digitais, o filme"}

Indígenas digitiais é aquele índio que se apropria da ferramenta e faz o uso dela pra ajudar sua comunidade, pra estar aproximando a sua comunidade, dar voz a sua comunidade, pra apresentar tudo o que vem acontecendo dentro da sua comunidade, certo? Mas também tem um outro tipo de índio digital que é aquele que incentiva aqueles os mais novos a tá usando essas ferramentas, a tá aprendendo, que são os anciões, são os mais velhos, que acham que essas tecnologias não é pra eles, esse também é um índio digital, esse também tá incluído dentro desse mundo digital, desse mundo virtual, porque ele sabe a importância que é essa ferramenta dentro das nossas bases, ele sabe a importância dela, ele sabe que nós vamos usar pra apoiar nossa causa, pra tá fortalecendo a nossa luta. Jaborandy@indiosonline.org.br em "Indígena Digitais O filme" (2010)

O excerto acima é uma transcrição da fala do índio cyber-identificado na legenda do filme, como jaborandy@indiosonline.org.br, personagem de "Indígenas digitais, o filme" (2010) de Sebastian Gerlic ${ }^{6}$. O documentário (em exposição no site www.indigenasdigitais.org), retrata o processo de indígenas de várias etnias do nordeste brasileiro produzindo conteúdo digital, organizando-se em redes colaborativas e, num viés reflexivo, opinando sobre a relação da tecnologia no contexto étnico do cotidiano dessas comunidades. Jaborandy fala sobre o que pensa ser propriamente um "indígena digital", num enquadramento de câmera muito singular no documentário, que sugere o personagem de frente a um espelho, em close, enquanto se pinta. A câmera age como parte do espelho, dirige-se ao rosto do indígena que se pinta aparentemente para um "ritual", ao mesmo tempo em que reflete sobre si mesmo e sobre sua condição de "indígena digital". Uma metáfora que também nos permite refletir que

se de um lado, nos últimos anos, as etnias indígenas se defendem e reafirmam as próprias especificidades através da tecnologia digital, de um outro, o digital indigeniza-se, tornando-se, na época contemporânea, pelo

6 O argentino Sebastian Gerlic é realizador audiovisual, publicitário e coordenador da ONG Thydêwá. Participa de vários projetos que valorizam e promovem o protagonismo a diferentes etnias indígenas brasileiras. (Pereira, 2007) 
menos em parte, étnico e local, enquanto habitado pelas culturas nativas, as mesmas secularmente excluídas pela linguagem política e pelos demais meios de comunicação." (Di Felice, 2005, p. 295)

A despeito da autoria do filme ser de um não índio, o produto é fruto de um amplo processo dialógico de índigenas e não-índigenas, envolvidos em ações afirmativas como a rede/ portal "Índiosonline" e o projeto "Arco Digital”, que visam, por meio da internet, ações de autodesenvolvimento e representatividade (Pereira, 2007). Nessa perspectiva, o filme contribui e chama a atenção para a presença indígena na rede e na sua total capacidade de adaptação cultural a essa tecnologia. Dentre várias interpretações profícuas e poéticas, a sugestão abordada no filme da metáfora do digital como um $\operatorname{arco}^{7}$, elemento tradicional da cultura indígena, expõe a relação do digital que se indigeniza e vice-versa. Nas palavras do índigena, cyber-identificado comonhenety@indiosonline.org.br:

o computador, ele serve com um arco, porque o arco tradicional seria pra caçar, pescar, defender o povo e trazer a caça, trazer a pesca e trazer subsistência dos povos e o computador também faz isso, ele faz a caçada, né.. uma caçada virtual, a gente procuramos os ministérios, as ongs e enviamos projetos através da internet, a gente elaboramos projetos planejado com a comunidade, enviamos, e quando esses projetos, eles é aprovados e aplicado na comunidade como fonte de renda pro povo, então é como se fosse uma grande caçada e o computador conectado à internet é como se fosse um arco, que a gente denominamos 'Arco Digital' (2010).

Assim como a presença étnica na rede, o filme aborda novas estratégias dos indígenas a partir do registro audiovisual de suas culturas e da ampla difusão deste produtos, e como essas estratégias podem contribuir cultural e politicamente para os povos envolvidos. Esboça desta forma uma apresentação híbrida, em uma abertura epistemológica, que busca, de forma iniciática sugerir processos de diálogo e partilha. É resultado de uma transição na lógica do indígena na condição de objeto representado para a de sujeito que se apresenta.

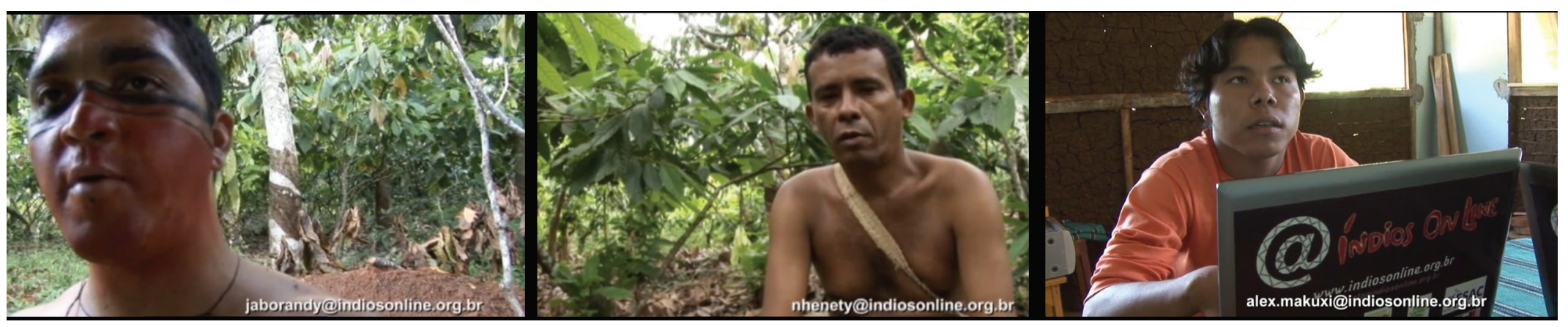

Fig.07 jaborandy@indiosonline.org.br fala sobre o que pensa ser um indígena digital.

Fig.08 nhenety@indiosonline.org.br compara o papel do arco ao da internet.

Fig.09 alex.makuxi@indiosonline.org.br relata ter conhecidos outras etnias através da internet.

$7 \quad$ “Arco Digital” é um nome de um projeto, coordenado pela ONG Thydêwá, decorrente da rede Índiosonline. 


\subsubsection{Trânsitos dialógicos: Da representação à apresentação}

O modo como eu vivencio o eu do outro difere inteiramente do modo como vivencio meu próprio eu; isso entra na categoria do outro como elemento integrante, e essa diferença tem importância fundamental tanto para a estética quanto para a ética. (Bakhtin, 2011, p. 35)

Além de não ser mais representado aí, o homem ordinário dá como representação o próprio texto, no e pelo texto, e ele reconhece ainda por cima o caráter universal do lugar particular onde permanece o louco discurso de uma sabedoria sábia. É ao mesmo tempo o pesadelo ou o sonho filosófico da ironia humanista e a semelhança de referencial (uma história comum) que dá credibilidade a uma escrita contando a "todo mundo sua ridícula desventura. (De Certeau, 2011, p. 58).

Michel Maffesoli (1998) sugere uma distinção e superação do conceito de representação pelo de apresentação que, nos parece, faz-se pertinente. A "representação", enquanto "palavra mágica da modernidade" (p.19), vivencia um claro declínio epistemológico. Como nos lembra o autor, este conceito também se encontra na "base da organização política" e, por conseguinte, associado às estruturas das relações de poder. Sua premissa seria a de "representar o mundo em sua verdade essencial, universal e incontornável", o que consiste, provavelmente, como sua maior contribuição a um projeto de modernidade. Neste caminho, o autor sugere sua substituição por uma "apresentação das coisas, que se contenta em deixar ser aquilo que é, e se empenha em fazer sobressair a riqueza, o dinamismo e a vitalidade deste mundo-aí" (p. 20). Ora, dinamismo este que, nos parece, é essencial a um processo de produção de conhecimento que não se paute por uma pura racionalização, portanto afirmação de um poderio estrutural, em relação a um dado objeto.

Segundo Bakhtin (2011, p. 35),

enquanto a representação de outro indivíduo corresponde plenamente à plenitude de sua visão real, minha autorrepresentação está construída e não corresponde a nenhuma percepção real; o essencial no vivenciamento real de mim mesmo permanece à margem da visão externa.

Para Bakhtin, a despeito da impossibilidade de representar "para mim a minha imagem, com certo esforço posso fazê-lo e então representa-la para mim, é claro que limitada de todos os lados como imagem do outro." (p. 34). A representação, neste sentido, ainda que leve consigo o prefixo auto - indicando um lugar próprio de origem do discurso, será sempre uma construção minha a partir do outro e do outro a partir de mim - muito embora, por vezes, de forma conflitiva. 
e hetero-representação, passa, em determinado momento de sua pesquisa entre os bororos, a preferir uma possibilidade de composição à representação:

Falar do outro ou fotografá-lo era ao mesmo espaço-tempo falar ou fotografar-me. Deste modo a minha definição inicial de auto-represetação se movia entre o pulsar dos dedos, o piscar dos olhos, o apontar do nariz, o apertar dos dentes. No fim, ao invés de "representação", das ambíguas definições de matriz realista, comecei a preferir composição, que conjuga estilos, códigos, expressões, linguagens, sons, imagens, diferentes entre si. Tornava-me outro em relação a mim mesmo. (p. 79)

Em lugar de representações totalizantes, a proposição de dialogismos sensíveis e dinâmicos numa apresentação em que não se possa "jamais esvaziar totalmente um fenômeno" (Maffesoli, 1998, p. 20). A apresentação, para Maffesoli, "é mais escrava do que senhora da realidade social ou natural", condição essa que expressa sua insuficiência determinante. Seu poderio é aberto, dialógico e polifônico, incapaz assim de qualquer tentativa de dominação ou esgotamento do fenômeno. Deste modo guarda também, para o autor, uma correlação com a noção de estilo, a qual

seja da época ou do que é próprio do observador que dele trata, requer um esforço de reflexão, e isso porque ele não revela conteúdo preciso algum, mas contenta-se em descrever um continente, uma forma, onde cada qual deve dispor-se a exercer sua própria capacidade de pensar. (ibid., p21)

O racionalismo, para o autor, busca sempre agir em via reta. O caminhar do imaginário, porém, é sempre incerto e sugere um saber raro, "um saber que, ao mesmo tempo, revela e oculta a própria coisa descrita por ele; um saber que encerra, para os espíritos finos, verdades múltiplas sob os arabescos das metáforas" (ibid., p.21). Entretanto, sabemos que a metáfora ou o pensamento metafórico, por sua vez, foram desde o momento inaugural da ciência moderna sendo definitivamente afastados das descrições científicas, num contexto em que se condenava tudo o que se assemelhasse ao subjetivismo religioso (Bairon, Torres, 2009). Ainda para Maffesoli, o caminhar do imaginário, de uma razão sensível, demonstra "um saber que deixa a cada um o cuidado de desvelar, isto é, de compreender por si mesmo e para si mesmo o que convém descobrir; um saber, de certa forma, iniciático.” (p. 21)

Seria este o saber iniciático que poderia tão bem expressar uma apresentação das coisas. É este o saber que, para Maffesoli, constitui o "vetor epistemológico privilegiado" (p. 168) do senso comum e que, para nós, é algo que permite a prática de novas formas de produção de conhecimento. Saber iniciático, que "revela e oculta a própria coisa descrita por ele", como a estratégia de Paulinho Kadojeba, em seu filme "Boé Eru Kurireu" - sobre o ritual fúnebre bororo - no qual que faz uso de texturas visuais sobre cenas do ritual proibidas de serem assistidas.

Por uma apresentação produzida diretamente por interlocutores indígenas, que explore 
trânsitos reflexivos, compreendemos uma abertura metodológica na qual se torna possível não só questionar o potencial sujeito da ação como também partilhar e redefinir seus objetos. Entretanto, pensar nessa metodologia potencialmente não disjuntiva, implica em levantar questões, sobre

como pode o trabalho intelectual, artístico e pedagógico 'lidar' com o multiculturalismo sem defini-lo de modo simplista como um espaço onde apenas os latinos podem falar dos latinos, somente os afro-americanos podem falar sobre os afro- americanos e assim por diante, com cada grupo prisioneiro de sua diferença reificada? (Shohat, Stam, 2006).

Uma possibilidade, nos parece, se apresenta em espaços transitivos de políticas do saber, cada vez mais frequentes, onde àqueles outrora representados praticam hoje formas de apresentar, partilhadas, nas quais torna-se possível, através da ênfase dialógica, repensar um processo de reflexão unilateral - tantas vezes próprio ao saber científico - através da prática de antropologias partilhadas. Neste caminho, não somente o exercício do feedback mostra-se fundamental, como a ênfase em estratégias de reflexividade, num círculo perene em que se registra o diálogo e se dialoga sobre o registro.

\subsubsection{TSÕ'REHIPÃRI: Reflexividade no cinema xavante}

Divino Tserewahú Tsereptsé iniciou sua formação como realizador audiovisual indígena através do projeto Vídeo na Aldeias ${ }^{8}$ em 1990. Desde então, realizou diversos filmes sobre importantes rituais de sua cultura e viajou o mundo para mostrar suas produções. Seu filme Tsö'rehipãri, no português Sangradouro, realizado em parceria com Tiago Campo Tôrres e Amandine Goisbault, foi sua última produção através do projeto Vídeo nas Aldeias. Nele, Divino resgata a história da chegada dos xavantes à missão salesiana de Sangradouro. Para tanto, recorre desde o relato dos anciãos, do padre da missão, assim como um diálogo com representações desse momento presentes em outros filmes ora demonstrando visualmente o que dizem os anciãos ${ }^{9}$, ora utilizando essa imagens como um contraponto crítico ${ }^{10}$. Nesse

8 O projeto Vídeo nas Aldeias se desenvolve, a partir de 1987, como um desdobramento do trabalho do CTI (Centro de Trabalho Indigenista), e sua proposta consiste na capacitação de indígenas para operar as tecnologias digitais de registro (câmeras, mesas de edição linear e depois softwares de edição não linear, etc.) que possibilite processos de autonomia e auto-determinação na produção do discurso fílmico a partir dos próprios realizadores indígenas. Para mais informações sobre o Vídeo nas Aldeias ver "Vídeo nas Aldeias: 25 anos" (2012) organizado por Ana Carvalho Ziller Araujo.

9 Como nas cenas (nos registros de Adalbert Heide) em que os xavantes aparecem sendo catequizados e aprendendo a escrever em cadernos, na lousa e a trabalhar com a enxada. Estas cenas reforçam o que acaba de dizer o ancião sobre o início da catequização salesiana.

10 Na cena inicial, intercalando com as imagens e narração do filme "Sertão, Entre os índios do Brasil Central" de Genil Vasconcelos, Divino narra aspectos negligenciados pelo que vemos no filme, como os massacres, epidemias e doenças que fizeram parte desse momento inicial de contato. 
contraponto, aspecto evidente de reflexividade que permeia o filme, Divino recorre ao diálogo dos próprios xavantes sobre sua cultura, sobre a influência da cultura do waradzu (branco), entre outas questões pertinentes ao cotidiano da comunidade.

Num certo sentido é possível questionarmos o quanto na ética de uma apresentação xavante, o conceito de reflexividade, por vezes explorado no horizonte da antropologia visual, não seria uma prática imanente. Por diversas vezes, durante nossas conversas com Divino, ele nos relatara seu meticuloso processo reflexivo e dialógico em que um filme nunca pode estar pronto sem que a comunidade, sobretudo os anciãos, o tenham assistido e aprovado. Este "método" é, de certo modo, consonante com o cotidiano xavante em que as principais deliberações são sempre definidas a partir dos anciãos.

De volta ao filme, a cena inicial parece emblemática do percurso reflexivo de Divino : Numa elipse, passamos do enquadramento do filme etnográfico ${ }^{11}$, em pb, de Genil Vasconcelos, que sobrevoa de um avião uma aldeia xavante e, na mesma perspectiva, a imagem colorida do filme de Divino - com uma distância temporal de exatos 60 anos $^{12}$ - vai se fundindo à imagem. A trilha sonora, não diegética, do filme de Vasconcelos segue estranhamente em fusão a uma outra música bastante popular: Eyes of the Tiger, tema do filme Rocky Balboa. Nesse plano, somos recebidos, pelo próprio filmaker xavante, na Aldeia xavante Sangradouro, que num plano geral dá um aceno de boas vindas ao lado da caixa de som onde a música é executada. As cenas seguintes mostram um carro na aldeia, uma partida de futebol onde também chama a atenção, ao fundo, uma antena parabólica e, por fim, Divino caminhando com sua câmera. Signos de um "progresso" que hoje fazem parte do cotidiano da aldeia.

Na relação do xavante com a imagem e com o "ser visto por si próprio", algo já corriqueiro em Sangradouro graças aos recorrentes trabalhos de Divino, presenciamos diferentes reações da comunidade diante da câmera. Quando Divino diz para uma criança "Menino, vem aqui que quero filmar você", esta lhe responde "Não, você vai roubar minha imagem". Em outra situação, quando uma senhora que pinta seu marido é filmada, ela diz: "A minha imagem nunca vai acabar depois que eu morrer". Polifonia reflexiva na qual a presença da câmera captura tanto a cautela da criança temerosa quanto o entusiasmo da senhora em relação própria imagem. Essas duas percepções opostas exemplificam duas diferentes perspectivas, sendo a primeira sobre a que os xavantes, muitas vezes, foram registrados e não puderam se ver - o aspecto político da “imagem roubada" ou mítico do congelamento da imagem - e, uma segunda possibilidade mais recente, na qual não só podem se ver como discutir o uso de suas imagens.

A reflexividade é exercitada desde as cenas iniciais do filme, quando a aldeia está reunida assistindo ao próprio filme Tsö'rehipãri, ainda inacabado, enquanto opina sobre as cenas e a montagem. Um método que, de imediato, nos remete a "Crônica de um verão" (1960), de

11 O filme até então vinha nos conduzindo com uma voz off caricata buscando situar os xavantes, do período do "primeiro contato", no exótico imaginário do "selvagem", utilizando adjetivos como "bravios", "ariscos", entre outros.

12 O filme “Sertão: Entre os Índios do Brasil Central”, de Genil Vasconcelos, é de 1949 e Tsö'rehipãri, de Divino Tserewahú, de 2009. 


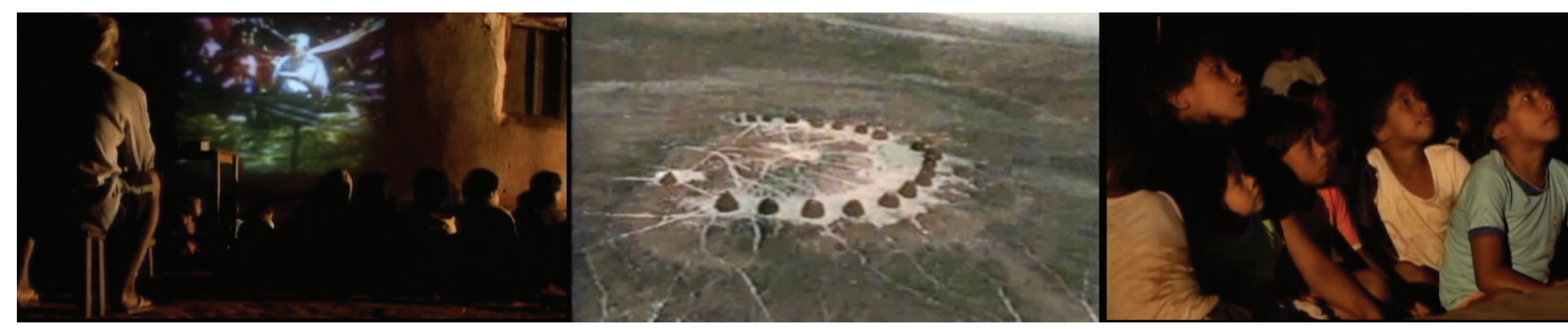

Fig.10 A aldeia Sangradouro reunida para assistir o filme Tsö rehipãri "ainda inacabado"

Fig.11 A aldeia Sangradouro vista de cima. Divino faz uma fusão da imagem, do mesmo plano, do filme de 1949 com o seu em 2009.

Fig.12 Crianças xavantes assistem a versão inacabada de Tsö rehipãri. Cena que faz parte do começo do "filme finalizado".

Jean Rouch e Edgar Morin, em que os protagonistas do filme discutem, durante a projeção do próprio, as relações criadas durante os registros e que agora fazem parte do filme. Caminhos reflexivos da antropologia compartilhada de Rouch à produção partilhada e Tserewahú.

\subsection{6 "Boé Eru Kurireu”, trânsitos dialógicos do audiovisual à Hipermídia}

Meu nome é Paulinho Ecerae Kadojeba. Hoje sou cinegrafista. Antigamente nossa cultura foi registrada pelo trabalho de não-índios. Eles fizeram muitas filmagens, fotografias e livros a partir de sua visão e interpretação que conseguiram dar com base em suas pesquisas, e foi com essa visão que fizeram a divulgação de nossas práticas culturais. Atualmente isso mudou. Somos nós os Bororo que estamos atuando nesse trabalho, apresentando uma versão a partir de quem vive na prática a cultura tradicional. Parte dessa cultura vamos mostrar nesse vídeo. Paulinho Ecerae Kadojeba, Hipermídia Boe Eru Kurireu, (2009)

Com a narrativa identificada acima, originalmente em língua bororo e com legendas em português, Paulinho Ecerae Kadojeba, introduz o espectador em sua própria versão do ritual fúnebre bororo, evento de extrema importância para a etnia.

O meio pelo qual temos acesso ao documentário de Paulinho é a hipermídia (que leva o mesmo nome do filme) Boe Eru Kurireu, no português "A Grande Tradição Bororo". A produção do documentário fez parte de um processo de partilha da produção de conhecimento, em que a montagem é assinada pelo xavante Divino Tserewahú Tserepsé a partir das filmagens do bororo Paulinho Ecerae Kadojeba. No interior desta interlocução entre Paulinho e Divino, chama ainda mais atenção, o fato de que as etnias bororo e os xavante foram, durante muito tempo, consideradas etnias inimigas. Divino e Paulinho dialogam no produto audiovisual, respeitando suas diferenças e sugerindo um interessante processo palinódico direcionado por um grande conjunto de aberturas para novos diálogos. Divino afirma que depois de realizar a montagem, decidiu exibir o filme do amigo bororo em sua aldeia xavante, processo que 
agiu como valorização da cultura do outro, permitindo novos fluxos e intercâmbios entre os realizadores indígenas, assim como entre indígenas das duas etnias.

Ao longo do processo de contato interétnico, diversas vezes os funerais bororos foram, como no caso do filme "Rituaes e Festas Bororo", representados numa lógica em que o registro negou, ou mesmo suprimiu, as vozes da alteridade. A possibilidade de uma realização fílmica criada e produzida a partir dos próprios indígenas (no Brasil), começou a se tornar viável, sobretudo, por meio da interlocução com os trabalhos do Turner, desde 1962, junto aos kayapós, posteriormente, com projetos realizados por instituições como o CTI (Centro de Trabalho Indigenista) e o projeto Vídeo nas Aldeias.

Por um lado, um segundo aspecto bastante relevante em "Boé Eru Kurireu”, é a crítica de Paulinho aos modelos de representação dos brado (não indígenas), no caso específico da emissora de televisão Rede Globo em seu programa Fantástico. Trata-se de um exercício reflexivo que contrapõe, na narrativa, a visão bororo de seu ritual e a versão realizada pela equipe jornalística do Fantástico durante o ano de 2003. Por outro lado, em seu documentário, Paulinho utiliza uma metodologia que amplamente alicerçou o modelo de representação dos não indígenas: a entrevista e a voz off. Até certo ponto, utiliza o mesmo método narrativo de seus “detratores", embora tomando o cuidado ético necessário em determinadas etapas do ritual. De modo distinto do filme televisivo, que exibiu em cadeia nacional imagens proibidas de serem vistas pelas mulheres, Paulinho faz uso de uma textura visual que cobre essas imagens não permitindo que sejam compreendidas visualmente, mas que não altera em nada as sonoridades da cena. Temos aqui uma tradução audiovisual da lógica inerente ao ritual, em que as mulheres podem ouvir determinadas etapas, mas não podem ver. O filme de Paulinho busca esmiuçar de forma estética uma diferente versão do evento. Paulinho também questiona, em sua própria crítica à emissora de $\mathrm{TV}$, o fato de se ao longo do contato com os missionários salesianos a prática do ritual fúnebre foi proibida, como foi afirmado na matéria do Fantástico. Paulinho reforça seu discurso embasado no depoimento de alguns interlocutores da aldeia.

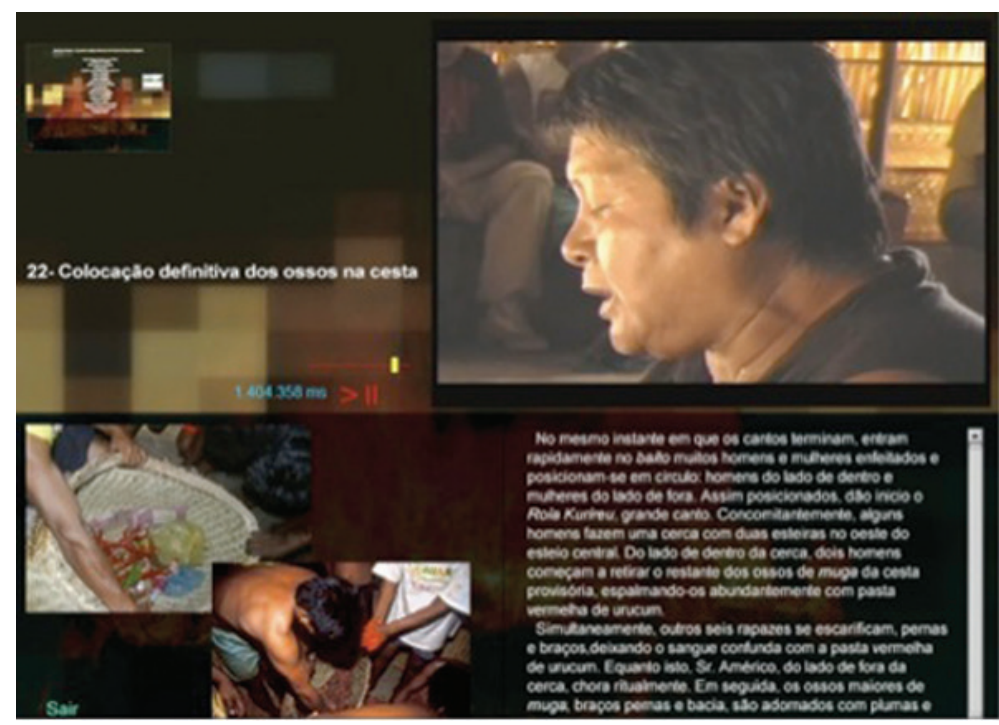

Fig. 13 Hipermídia "Boé Eru Kurireu”, ambiente digital que apresenta um filme de um bororo, montado por um xavante, e uma dissertação de mestrado. 
A mudança propiciada no contexto das autorias múltiplas na produção partilhada do conhecimento, apresenta uma alternativa à assimetria tradicional das representações monológicas. No produto/hipermídia "Boé Ero Kurireu", hibridizaram-se um documentário bororo e seus sensos críticos, uma pesquisa acadêmica e um conceito inerente ao processo. Essa forma reticular de produzir conhecimento questiona as estrutura rígidas e formais da produção do conhecimento científico, que elege as narrativas acadêmicas como o protagonista do Saber.

Nos antigos filmes etnográficos, por exemplo, vozes confiantes e 'científicas' falavam a 'verdade' sobre os povos nativos, impossibilitados de replicar; já as novas produções buscam uma 'prática participativa', uma 'antropologia dialógica', uma 'distância reflexiva' e uma 'filmagem interativa'.

(Shohat, Stam, 2006, p. 67)

Num mesmo ambiente habitam polifonias, em diferentes autoridades de níveis taxionômicos, discursivos e estéticos, sendo que o texto acadêmico continua em sua matriz textual e o produto indígena é o filme. Podemos afirmar que uma espécie de inconsciente óptico age na forma de sobreposições das autoridades indicadas (Krauss, 1999). No interior desta experiência, também habitam diversas formas de vida da produção de conhecimento: o filme como linguagem indígena, o texto conceitual da dissertação de Sérgio Sato e nossa proposta de reticularidade fílmica, definida pelas formas de vida anteriores.

\section{Capítulo II - Cotidiano, Senso Comum e Hipermídia}

\subsection{Senso comum e produção de conhecimento}

O tom de anteontem' - o do racionalismo abstrato - já não convém, num momento em que a aparência, o senso comum ou a vivencia retomam uma importância que a modernidade lhes havia negado. E, ainda que seja sob forma de constatação, importa assumir, intelectualmente, a afirmação da existência, o "sim" à vida a que tudo isso incita. (Maffesoli, p.16, 1998)

É nos séculos XVI e XVII que têm início a ruptura entre o conhecimento científico e a experiência estética, calcada na sobrevalorização de uma noção de verdade atrelada à escrita verbal. Desde o método de interpretação da Natureza, a partir da observação escrita - assumindo a categoria de Ciência -, como nos falam Bairon e Torres (2009) sobre o trabalho do médico inglês William Harvey (ibid, p. 10), a Natureza,

com todo seu espetáculo inexplicável, passou a ser considerada o grande livros das criaturas de Deus. Qualquer texto deveria ter o seu significado 
do modelo de leitura do 'Livro da Natureza”" (ibid., p.10)

No surgimento da ciência moderna, o solapamento da experiência estética e das figuras de linguagem como possibilidades de compreensão dos fenômenos do mundo, sentenciando o afastamento entre ciência e senso comum, constituía um caminho em que

(...) esse tipo de compreensão parece não só ter definido a escrita metodológica como o caminho mais fidedigno do conhecimento, como, até mesmo, a única forma de compreensão confiável, (Bairon, Torres, 2009, p.11)

No início do século XVIII, Vico (2008) valoriza o sensus communis como uma herança estética não interrompida desde a antiguidade. Neste sentido, enfatiza que as artes cultivadas nas coletividades deveriam ser novamente trazidas à tona para corrigirmos o que considera como equívocos racionalistas. Entretanto Vico era, "nesse contexto, uma voz quase isolada" (Bairon, Torres, 20009, p. 10).

Herdeiro de uma crítica à razão pura, inerente ao método científico clássico, Maffesoli (1998), em seu "Elogio da razão sensível”, nos fala sobre uma razão, de certo modo, solipsista, "enclausurada na consciência pura", que privilegia um lugar distanciado do "mundo circundante". Algo que consistiria "a fonte do drama do homem moderno", legitimando poderes, normas e uma razão institucionalizada, onde predomina,

nesse delírio de abstração, uma escalada de potência, uma fuga pra frente, que se encontra tanto nas produções acadêmicas quanto nos mais sofisticados arcabouços de uma intelligentsia sem amarras, não esquecendo a algaravia tecnocrática, ou o discurso vazio dos políticos. (ibid., p. 34)

No contexto das produções acadêmicas, compreendemos na valorização extrema da "razão" e, consequentemente, da matriz escrita como uma prerrogativa de decifração da verdade, como a tônica que solapou, em grande parte, a partilha como horizonte possível na produção do conhecimento. Valoriza-se o exercício solitário do sujeito pensante, "coisas que inauguram uma visão dogmática e normativa do homem em sociedade (ibid., p. 34)", expressão de uma "exacerbação da ciência", em que o "corte epistemológico" produz uma defesa "com meios que mais pertencem a uma lógica militar do que à do verdadeiro debate de ideias" (ibid., p. 35). Ora, deste modus operandi do racionalismo, desta estática e rígida defesa, nos parece, alimentase uma contradição na condição de que a razão devaria ser "essencialmente dinâmica" (ibid., p. 36). Neste sentido, entre a continuação de um racionalismo puro ou a prática de um puro irracionalismo, há de se encontrar uma "deontologia" ambivalente que, híbrida, reconheça-se enquanto uma "organicidade fecunda" (ibid., p.19).

Geertz (1997), por sua vez, compreende o senso comum como um sistema cultural em que "se baseia nos mesmos argumentos em que se baseiam outros sistemas culturais semelhantes: aqueles que os possuem têm total convicção de seu valor e de sua validade" (p. 116). O "bom 
senso", "isto é aquilo que o homem comum pensa quando livre das sofisticações vaidosas dos estudiosos" (p. 116), constitui uma manifestação sensível homem ordinário que expressa “(...) critério, inteligência, discernimento e reflexão prévia na lide com os problemas cotidianos, de uma forma cotidiana" (p. 115). Trata-se de uma "interpretação da realidade imediata" (p. 115), enquanto uma construção histórica, pois é "sujeito a padrões de juízo historicamente definidos" (p. 116). Compreendemos, neste caminho, que o bom senso expressa saberes do senso comum de uma época, ainda que possa divergir "dramaticamente de uma pessoa para outra", mas que se configura, deste modo, como um "sistema cultural", "embora nem sempre muito integrado" (p. 116).

É necessário ressaltar que a perspectiva que aqui apresentamos do senso comum enquanto saber local, objeto de partilha, - seja através de Geertz que o compreende enquanto sistema cultural ou como fonte de uma razão sensivel para Maffesoli - não busca diminuir a importância do exercício científico ao valorizar as táticas cotidianas, atreladas ao senso comum, na produção de seus peculiares saberes. Contudo, afirmamos, sim, uma necessidade de divisão, calcada no conceito de partilha $^{13}$, que - através de uma reflexão sobre como atuam as estruturas institucionalizantes de poder na forma da produção do conhecimento - se paute por uma ética epistemológica, através do exercício dialógico da Produção Partilhada. Este viés, nos aponta a possibilidade de construção de produtos acadêmico-comunitários partilhados.

Defendemos, por exemplo, a possibilidade de que um filme produzido por um interlocutor de uma comunidade indígena brasileira possa habitar um produto acadêmico mas que, entretanto, que não o seja na distante condição de objeto. Filme este que é ou pode ser, par excellence, um singular registro do exercício de partilha. Desconstrói-se, assim, a objetivação do método que relega ao objeto da pesquisa, em um papel coadjuvante incrustado a uma monologia disruptiva. O joguete sujeito-objeto não poderia, nesta compreensão, esboçar a partilha do conhecimento, senão a (re) afirmação de um "conhecimento" advindo de um lugar arbitrário, não dialógico, onde nos acostumamos a esmerar nossos muros e a, pacientemente, afastar-nos cada vez mais das compreensões de mundo do senso comum. Parte deste distanciamento, nos parece, se dá por conta de um desequilíbrio de incertezas. As incertezas genéricas cotidianas do senso comum muito pouco dialogam com as incertezas científicas departamentizadas, a não ser de modo disruptivo, onde pouco há lugar para o diálogo. É como se pudéssemos afirmar que a forma de produção de conhecimento do senso comum, ao contrário da científica, pode se alicerçar em tudo e nada ao mesmo tempo - incômoda abrangência. Geertz (1997) observa que

a religião baseia seus argumentos na revelação, a ciência na metodologia, a ideologia na paixão moral; os argumentos do senso comum, porém, não se baseiam em coisa alguma, a não ser na vida como um todo. O mundo é sua autoridade" (ibid., p. 114).

13 A etimologia da palavra "partilha" é derivada do lat. particûla. A partícula seria a expressão de uma mínima parte. A partilha, por sua vez, expressa a possibilidade de uma divisão, fragmentação desta (s) parte (s). 
É este todo do mundo-aí, que consiste sua perene abertura. Não há, desta forma, obstáculos a possibilidades de partilha de saberes mas, pelo contrário, um convite. Algo, nos parece, tão distante do substrato científico calcado em uma metodologia monológica, onde

O que começou a entrar em jogo no caminho pós-iluminista foi exatamente o tema do não esquecimento da colectividade. Nos aspectos sociais, políticos e até mesmo éticos, tais questões foram profundamente desenvolvidas. (Bairon, Torres, 2009, p.13)

O que, entretanto, não se dera de igual forma "no que tange o domínio do discurso" (ibid., p.13) na lide com as manifestações culturais e cotidianas, e nas estratégias de produção de conhecimento a partir do método clássico. Assim, ainda que uma miríade de interlocuções possam ser feitas (entre diferentes autores, teorias, metodologias), no bojo deste método há sempre de prevalecer, de forma uníssona, uma autoridade científica sobre o diálogo, um recalcamento das coletividades e, consequentemente, das conectividades no discurso científico.

Encontramos na insistência do método clássico, um fenômeno que, tantas vezes, isola da pesquisa a dinâmica do tempo das táticas cotidianas. A estratégia, nesse sentido, aponta, para De Certeau (2011), um predomínio sob um espaço rígido e institucionalmente definido,

suscetível de ser circunscrito como algo próprio e ser a base de onde se podem gerir as relações com uma exterioridade de alvos ou ameaças (os clientes ou os concorrentes, os inimigos, o campo em torno da cidade, os objetivos e objetos da pesquisa etc. (ibid., 2011, p.97).

Como ainda nos aponta De Certeau,

é necessário que se apaguem as práticas linguísticas cotidianas (e o espaço de suas táticas), para que as práticas científicas sejam exercidas no seu campo próprio. (...) Tal arte fica excluída e os seus autores, lançados para fora do laboratório, não só porque toda cientificidade exige delimitação e simplificação de seus objetos, mas porque a constituição de um lugar científico, condição prévia de qualquer análise, corresponde a necessidade de poder transferir para ali os objetos que se devem estudar (ibid.,p. 77)

Ora, nos parece evidente que o que se pode compreender como um "campo próprio" da cientificidade, como espaço de outorga de plausíveis compreensões de mundo, constitui hoje, propriamente, um grande problema epistêmico, dado que, nesta lógica, compreende-se o exercício científico, sobremaneira, como uma condição de transferência de saberes, disruptiva, em que o senso comum, tornado objeto, presta-se a função de abastecimento de um manancial de matérias primas (sociológicas, antropológicas, biológicas, etc), sem que, inúmeras vezes, receba de volta os frutos de uma partilha que lhe cabe. 
fui disciplinado a enxergá-las de outro modo. E, deste modo, as minhas mãos operacionais passaram a ser educadas para uma compreensão textual na execução de seus processos, de forma que a mão é o que o meu bom senso (Geertz, 1997) determina.

Uma vez mais este exemplo contido na sabedoria de Marinoni me pareceu e com frequência continua a parecer, uma complexa compreensão da tecnologia enquanto um atributo culturalmente imanente - uma híbrida colher/mão -, situação tranquilamente observável, de modo geral, em diferentes comunidades indígenas. Imanência que pode ser compreendida, por exemplo, quando a câmera digital, no contexto dos "Indígenas digitais", expressa a metamorfose do arco "analógico", ferramenta de caça e de luta, para o arco digital, que passará em seu universo simbólico a também proporcionar caças e lutas ${ }^{14}$. Diante destes exemplos, não exagerado nos parece apontar como presente na compreensão de mundo de um saber que não sabe que sabe, da "Douta Ignorância" "15, do "discurso que esconde aquilo que sabe (em vez de esconder o que ignora)" e que "teria precisamente valor 'teórico' enquanto pratica o que sabe" (De Certeau, p.122, 2011), uma antecipação conceitual de certos desenvolvimentos tecnológicos. Neste sentido, exemplos importantes são os conceitos de rede e reticularidade, tão bem compreendidos no cotidiano e sabedoria de comunidades indígenas, assim como na de comunidades (por vezes urbanas) menos favorecidas, como as favelas e movimentos organizados da sociedade civil. Seria possível imaginar que, nestas cotidianeidades, a reticularidade tenha sido sempre uma prática cotidiana imanente? Numa compreensão conectiva, algo que une mãos a colheres, arcos, filmadoras e computadores. No provérbio popular, Marinoni me dera uma verdadeira colher de chá ao partilhar empiricamente um pensamento tão complexo.

\subsubsection{Tomõre: $O$ método Vertov no cine-olho cotidiano xavante}

Divino Tserewahú tem um apelido bastante peculiar entre os xavantes. Não é incomum que em Tsö'rehipãri, sua aldeia, o chamem por "Tomõre” que, na língua xavante, significa "olho da câmera". Os xavantes costumam assim se referir a ele, como algumas vezes me fora explicado, pela recorrência com que Divino percorre a aldeia sempre empunhando sua câmera a registrar o cotidiano da comunidade e como, neste cotidiano, a figura do tomõre é já indissociável. O que nos sugere uma aproximação ao cine-olho (ou seria o "olho da câmera"?) vertoviano, método cinematográfico em que segundo Ribeiro (2006) sobressairia - no cinema de Dziga Vertov - "uma história do cotidiano" (Ribeiro, 2006). Assim como em "O Homem da Câmera de filmar" (1929), em que

a audiência é reintroduzida, por meio de um processo cinematográfico

14 Conforme analisamos no primeiro capítulo em "Trânsitos da apresentação: Indígenas Digitais, o Filme"

$15 C f$. "A 'douta ignorância': Bordieu" (p. 110), análise de Michel de Certeau, em "A invenção do cotidiano: Artes de fazer" (2011). 
de reincorporação ou de agregação perceptiva, às condições de representação em cinema: como audiência e como atores sociais do processo representado, isto é como representação e auto-representação" (Ribeiro, p. 48, 2006)

, “Tsö'rehipãri”"16, de Tserewahú, busca reintroduzir sua audiência, ou melhor, sua própria comunidade xavante como, mais do que "atores sociais" e "audiência", co-autores do filme.

Interessa à Tserewahú, em sua construção da história do cotidiano xavante, uma metodologia - através de uma ética-fílmico-epistemológica ${ }^{17}$ - que insira a comunidade no processo fílmico. Não obstante o filme de Vertov sugira uma "representação do cotidiano" através de uma "auto-encenação da cidade “ (p. 50), poderíamos dizer que os filmes de Tserewahú, a seu modo, mais do que possibilitarem uma espécie "auto-encenação" de sua aldeia xavante, convidam à comunidade a adentrar o filme em um processo reflexivo. Sobre o seu primeiro filme a retratar o ritual Wapté Mñoño, Divino diz:

(...) levei uma primeira versão para a aldeia. O pessoal estava ansioso, curioso de ver. A aldeia parou, silenciou, eles apressaram a gente: 'nos temos que assistir logo para matar a saudade!'. É sempre assim depois que um grande evento acontece. Quando ele viram a primeira versão não tinha nada. Era uma TV 29 polegadas. Coloquei no alto, todo mundo viu. Cada vez que os velhos falavam sobre uma cena que aparecia, eu parava, perguntava e anotava tudo o que eles diziam. 'Para, para', eles falavam. Volta um pouco. Isso tem que mudar!' E eu anotando tudo. Dessa primeira reunião, veio a orientação de mudança de dezoito sequências do filme. Voltei de novo para a ilha de edição, mostrei para o Tutu: 'olha, vamos assistir. Os velhos falaram dessa imagem aqui, é para tirar. Essa imagem a gente tem que arrumar a tradução'. Voltei para a aldeia de novo com a segunda versão e fizemos tudo de novo. Mas aí eles falaram: 'olha, o começo vocês tem que mudar, vocês tem que colocar o processo dos meninos, como era antes'. Anotei de novo. Foi um processo, uma experiência! Mudamos o começo do jeito que eles explicaram, colocamos a luta, mudamos o final. E, mais uma vez, levei o filme para os velhos. Dessa vez, enquanto eu exibia liguei para o Tutu e deixamos a conversa rolar para ele ouvir. E já fomos fazendo as mudanças. Levamos três, quatro meses na edição do material do Wapté. Na terceira viagem, fiquei lá, trabalhei e disse: 'olha agora estou cansado de viajar, eu tenho família para cuidar também'. Mas os velhos cobraram: 'você tem que aguentar, não foi você que trouxe seus colegas? Agora tem que aguentar, tem que finalizar!'. Então arrumei uma caixa de som e exibi o filme para eles. Quando terminou ninguém falou nada, depois de um tempo o líder levantou e disse: 'Tá todo mundo de acordo assim?', e todo mundo concordou. 'Está aprovado, pode fazer assim. O Wapté está bem construído, as imagens, as traduções estão certinhas. Deixa assim agora, não mexe mais. Agora você tem que finalizar'. Depois que o velho falou todo mundo aplaudiu." (Tserewahú in Araújo, p. 59, 2011)

16 Conforme analisamos no primeiro capítulo em "Tsö’rehipãri: Reflexividade no Cienma Xavante" 
Como compreende Ribeiro (2006), sobre o filme "O Homem da câmera de filmar", "o filme constitui um documento etnográfico do cotidiano da cidade e da criação cinematográfica." (ibid., p.50), assim como compreendemos que, para Tserewahú, não só seu filme Tsö 'rehipãri (2009) ou Wapté Mnhõnõ, Iniciação do jovem xavante (1999), por exemplo, constituem documentos etnográficos de sua aldeia e, consequentemente, de seu processo de criação cinematográfico, como seu próprio fazer fílmico evidencia essa condição. O tomõre xavante encontra o kino-glaz (cine-olho) soviético, em sua especificidade de um cinema cotidiano.

\subsection{O processo hipermidiático como Partilha do Conhecimento}

De Certeau (2011), em sua dedicatória ao "homem ordinário", que introduz o primeiro capítulo de "A invenção do Cotidiano", nos diz:

Este herói vem de muito longe. É o murmúrio das sociedades. De todos os tempos, anteriores aos textos. Nem os espera. Zomba deles. Mas, nas representações escritas, vai progredindo. Pouco a pouco ocupa o centro de nossas cenas científicas. Os projetores abandonam os atores donos de nomes próprios e de brasões sociais para voltar-se para o coro dos figurantes amontoados dos lados, e depois fixar-se enfim na multidão do público. (ibid.,p. 55)

É de um saber ordinário, das artes de fazer circunscritas na compreensão de mundo de interlocutores de distintas cotidianeidades (como a xavante e karajá) em seu diálogo com uma pesquisa em Ciências da Comunicação, que se insere, para nós, um problema crucial deste percurso. Poderíamos compreender que, em comunicação digital, produtos que expressem diálogos (como o audiovisual e a hipermídia) - intercomunitários - podem esboçar uma produção partilhada do conhecimento?

Compreendemos, de acordo com Bairon e Torres (2009) que,

de uma certa forma, os desafios que nos interstícios das tecnologias digitais está a se desenvolver, apela à mescla de mundos de teorias, que se relacionam com princípios revolucionários inovadores como a navegação não-linear e, fundamentalmente, a produção conceitual de ambientes nos quais devemos imergir e recriar sentidos para a própria pesquisa." (ibid., 2009, pp. $15-16)$

A multiplicação de pesquisas, ainda que raras no Brasil, nas quais existe uma proposição da Hipermídia como forma de produção de conhecimento científico, traz à tona o ensejo de enveredar por questões extremamente atuais e urgentes: A possibilidade de superação de representações monológicas, da quais muitas vezes "foi eliminada a voz da alteridade" (Canevacci, 1996. 
p. 40). Defendemos que, nas mais diversas e singulares comunidades, através de um método dialógico, uma produção partilhada de conhecimento pode ser possibilitada, dentre vários fatores, pelo uso das novas tecnologias na comunicação digital através de estruturas conectivas, reticulares e alineares, nas quais

A questão da linearidade ou não-linearidade no encontro entre educação e novas tecnologias digitais não é um detalhe descritivo de uma possível potencialidade midiática, mas a condição essencial do discernimento que pode, ou não, promover a soma da tradição da escrita com as nossas concepções contemporâneas de capacidade intelectual. (Bairon, 2002)

Nesse sentido, a linearidade de um produto textual, a despeito da possibilidade de atuar de forma hipertextual (através de notas de rodapé, referências, etc.), dificilmente poderia expressar a polifonia de sentidos presente no encontro de comunidades. Além disso, a tradição da escrita, dada sua falta de dinamicidade dialógica, atua muitas vezes na contramão da possibilidade de construção de produtos partilhados. O presente trabalho expressa, em parte, essa contradição. As comunidades com as quais desenvolvemos os trabalhos ao longo da pesquisa encontramse no texto acadêmico somente de forma descritiva - a partir de uma autoria - ainda que esta apresente os outros produtos e processos - não textuais - sob os quais buscamos o exercício da produção partilhada. Deste modo, compreendemos o presente produto como uma descrição teórico-metodológica de um processo que se desdobrará em novos produtos futuros, valorizando a hipermídia enquanto expressividade digital que pode enfatizar o aspecto dialógico do encontro universidade-comunidade.

Bairon e Ribeiro vêm, desde 2004, desenvolvendo um trabalho modelar sobre a (inter)culturalidade Afro-atlântica ${ }^{18}$ em que utilizam a hipermídia, como eixo epistêmico e expressividade digital resultante do diálogo universidade-comunidade. No trabalho de pesquisa em curso, a construção da hipermídia é feita de forma partilhada, ou seja, os interlocutores da comunidade e os pesquisadores acadêmicos, a partir de uma matriz de banco de dados, dialogam sobre os produtos, sua construção imagética e sonora, assim como as potenciais conexões reticulares, criando assim uma espécie de roteiro partilhado. Condição essa que resulta na

18 "O Projeto é uma iniciativa interdisciplinar de investigadores e professores universitários brasileiros e portugueses que pesquisam em parceria com a comunidade de Jequitibá MG, desde o ano 2004. Determinados em estreitar relações científicas, comunitárias, culturais e educacionais no espaço da lusofonia. Situa-se no âmbito da comunicação, da antropologia e da história da cultura e privilegia a utilização sistemática e intensiva da prodeução de mídias aplicadas à criação de materiais didáticos para o ensino. $\mathrm{O}$ projeto adotou como unidade temática a (Inter)culturalidade Atlântica (ver site: www.reticularidade.org), focalizando a sua dimensão reticular (em rede), transnacional, transcultural e interdisciplinar. A ênfase é dada à complexa rede histórica, social, cultural e artística da cultura africana transatlântica. Além do Brasil (interior de Minas), já foram iniciadas as pesquisas (filmagens) no Uruguai, Argentina, Cuba e Cabo Verde. Os elementos em comum que encontramos e registramos até aqui, indicam o ritual da Coroação de Reis Congo, ainda fortemente presente no Brasil, como um dos grandes elos da (Inter)culturalidade Afro-atlântica. A pesquisa tem possibilitado a produção de material fílmico, fotográfico e de áudio, sendo que toda produção conta com a participação ativa de membros das comunidades.", retirado do currículo lattes do prof. Dr. Sérgio Bairon. Acessado em 03/04/2012. 
realocação do "homem ordinário", não mais enquanto objeto a ser estudado, mas como vetor da produção do conhecimento em um produto científico.

Na proposição hipermidiática, enquanto produto/acontecimento estético que contemple a Produção Partilhada, o diálogo deve assumir uma categoria central para os diversos interlocutores da obra na qual,

Em síntese, a hipermídia deve atuar como uma comunidade de comunicação, reconstruída a cada instante como o mundo da linguagem partilhada (Bairon, 2010, p.10)

\subsubsection{Táticas de Partilha, a construção do diálogo}

Em ciências humanas em particular a coisa mais importante é o que, em nosso jargão, chamamos de "feedback". Isto é, o que pensam as pessoas que estudamos. E, nesse campo, eu e alguns colegas de Nanterre criamos uma antropologia nova, chamada "antropologia compartilhada". Essa antropologia compartilhada, para lhes dar um exemplo bobo é: Se perguntamos a um padre totêmico se ele acredita em Deus, a única possibilidade é que ele possa responder: 'E você?' É um ser humano que questiona outro ser humano. (Rouch, 1999)

Quanto da sugestão da antropologia compartilhada de Jean Rouch poderia expressar uma partilha de saberes, através do produto fílmico? Nesta questão particular, cabe a crítica sobre que, em parte de seus filmes etnográficos, Rouch não teria de fato praticado uma antropologia compartilhada, senão a afirmação de um olhar por vezes objetivo, descritivo e distanciado, como criticado certa vez pelo cineasta senegalês, Ousmane Sembène, em uma entrevista com o mesmo Rouch, em 1965: “O que eu tenho contra você e os africanistas é que vocês nos olham como se fôssemos insetos", diria Sembène ${ }^{19}$. A despeito da defesa de Rouch de que poderia haver possibilidades conectivas até mesmo entre formigas e culturas similares, a fala de Sembène evidencia um aspecto não dialógico de seu método. Entretanto, em filmes como "Crônica de um Verão" (1960), Rouch, junto de Edgar Morin, praticara uma espécie compartilhamento antropológico, ao dividir com os interlocutores (com os quais o filme se relacionara) a possibilidade de participar - numa espécie de coautoria - do desenvolvimento da investigação sobre a temática proposta e sobre o percurso fílmico, e, também, como um exercício reflexivo, utilizar esses diálogos como parte do produto final. Uma metodologia que, neste sentido, inspira partilhas dialógicas.

$\mathrm{Na}$ presente pesquisa, buscamos desenvolver táticas dialógicas através dos seguintes

19 Entrevista disponível em http://cine-africa.blogspot.com.br/2011/01/um-confronto-historico-entre-jeanrouch.html. Acessado em 30/05/2011. 
percursos: 1. Aceitação e acolhimento por uma determinada comunidade 2. Partilha de saberes teóricos e técnicos, in loco, a partir de objetivos em comum. 3. Feedback conceitual: retorno e aprendizado sobre os saberes locais durante o trabalho in loco. 4. Feedback partilhado: convite aos interlocutores das comunidades à participação em atividades acadêmicas, no espaço acadêmico. 5. Devolução dos produtos audiovisuais e da pesquisa às comunidades.

Estas cinco etapas, alicerçaram o desenvolvimento das atividades no horizonte da construção dialógica, universidade-comunidade, em nossa experiência com as comunidades xavante, karajá e a Escola de Comunicações e Artes da USP.

Entre quem tem o poder de enquadrar o outro e quem deveria continuar a ser enquadrado - para ser um eterno panorama humano - se ossificou uma hierarquia da visão que é parte de uma lógica dominante a ser posta em crise na sua presumida objetividade. É insuportável - política e etnograficamente - que na comunicação digital proponha-se um neocolonialismo medial como uma divisão hierárquica entre quem representa e quem é representado, quem filma e quem é filmado, quem enquadra e quem é enquadrado. (Canrevacci, 2012)

Como sugestão metafórica-conceitual às táticas de partilha, en.quadra.to.men - anagrama de enquadramento - sugere a partilha do processo fílmico, in loco, como um caminho a ultrapassar a rigidez mecânica da relação sujeito-objeto. "En quadra", aponta uma sugestão metodológica de afirmação da necessidade de realização de trabalhos de campo, para além dos muros dos herméticos círculos acadêmicos, que alicercem horizontes de possíveis diálogos. "To men" expressa uma condição ético-epistemológica da partilha e do retorno do produto "às pessoas/homens", num sentido genérico, das respectivas comunidades com as quais a pesquisa e o pesquisador tenham se relacionado. Processo de construção de um além-margem, devir fílmico no caminho de uma Partilha do Conhecimento que extrapole a mera realização do produto audiovisual. Defendemos que para "enquadrar" faz-se necessário o "desenquadrar", indo além dos limites do quadro, dos limites hierárquicos enquadrantes em que reproduz-se uma fragmentação na qual permanecem de um lado o privilégio de uma chancela cientifica e de outro o senso comum tornado objeto. 


\section{Capítulo III: Diários de partilhas}

Buscamos apresentar a partir dos relatos e das fotos dos diários de partilha, as proposições que, no horizonte desta pesquisa, compuseram o alicerce de seu referencial teórico-metodológico. O presente trabalho consiste em uma das etapas do desenvolvimento de pesquisas com ênfase na produção partilhada do conhecimento que temos elaborado no CEDIPP. Os diários de partilha compõem o registro etnográfico de texto das quatro etapas de trabalho de campo: 1. Curso de Formação de Cineastas Indígenas, Aldeia xavante Sangradouro 2. Registro do ritual Hetohokã karajá, Aldeia Fontoura. 3. Registro do ritual Wapté Mñoño, Aldeia xavante Sangradouro. 4. Edição no filme karajá, ECA - USP.

\subsection{Partilha I: Aldeia Sangradouro - "Auwé Tsiwadzari: Curso de Formação de} Cineastas Indígenas"

O curso de formação de cineastas indígenas aconteceu na aldeia xavante Tsö'rehipãri (Sangradouro), de 10 a 22 de janeiro de 2011, e foi organizado pelo Cedipp (Centro de Comunicação Digital e Pesquisa Partilhada) da ECA-USP e pelo Programa de Apoio ao Realizador Indígena (PROARI), ligado ao Museu das Culturas Dom Bosco, de Campo Grande. $\mathrm{O}$ evento consistiu em oferecer curtas oficinas sobre a linguagem audiovisual para alunos de 4 diferentes etnias (xavante, bororo, kuikuro e kalapalo), através de professores indígenas e não indígenas. Ao final do curso, os cinco curtas-metragens produzidos pelos grupos foram postados no canal de youtube, criado para o evento, "Auwé Tsiwadzari” (www.youtube.com/ auwetsiwadzari).

Ao chegarmos em Campo Grande - Jota Beck e eu - fomos muito bem recepcionados por Sérgio Sato e sua filhinha Hyté. Logo no começo do dia conhecemos o Museu das Culturas Dom Bosco, um espaço insólito, ao qual Sato e Aivone dedicam muita pesquisa, zêlo e carinho. A proposta do museu re-significa conceitualmente o espaço museográfico destinado à etnologia e etnografia, numa proposta em que pesam fundamentalmente os aspectos dialógicos na relação do museu e as culturas que habitam o espaço, chegando mesmo a oferecer uma "imersão ao contrário", nas palavras de Sato, na perspectiva de que os próprios indígenas, os quais lá tem suas etnias apresentadas, imergem no local para pensar a lógica de sua própria exposição. Um dos destaques são os espaços reservados às culturas xavante e bororo, com quem Sato e Aivone naturalmente tem uma relação mais próxima e duradoura. Neste espaços aconteceram inclusive rituais sacralizados pelos próprios indígenas como uma estratégia para lá manter vivo os objetos de sua cultura material. Depois da indescritível experiência do museu, fomos para a casa de 
Sato e finalmente conhecemos Aivone (que até então eu só havia conhecido através do filme de Paulinho), que nos presenteou com seu livro, fruto de sua pesquisa de doutorado, sobre as possibilidade de partilha entre comunidades indígenas e museus (o museu inserido na aldeia), com ênfase na participação de membros da comunidade no processo. Não poderíamos imaginar uma melhor recepção. A imensa hospitalidade de Sato e Aivone fizeram, em mim, crescer ainda mais a admiração que já nutria pelo seus trabalhos. Tudo sendo caprichosamente completo pela alegria e esperteza sem-fim da menina Hyté. Uma pena que tenhamos tido apenas um dia para compartilhar ideias e conhecer o acervo do museu, assim como o trabalho de Sato e Aivone. Mas a brevidade do evento ensejou a afirmação recíproca da necessidade de novos e frequentes encontros. Ainda na nossa despedida, Aivone alertara: “- Preparem-se para esta viagem, pois uma vez neste universo, não vão mais conseguir sair dele”. Com o espírito agraciado partimos para tomar o ônibus que nos levara de Campo Grande à Rondonópolis, de Rondonópolis à Primavera do Leste e de Primavera à Aldeia Sangradouro.

Fizemos o trajeto de Campo Grande à Rondonópolis durante a madrugada (saindo às 11 da noite e chegando às 7:30 da manhã) com o peito cheio de uma boa e já teimosa saudade do dia passado em Campo Grande. Fomos de Rondonópolis à Primavera, em duas horas e quarenta de viagem, e lá encontramos Divino que nos recebeu com um sorriso no rosto e com a impressão de que já éramos conhecidos de longa data. Divino e seu irmão João nos levaram de carro para a reserva indígena de Sangradouro. No caminho conversamos com sobre as antigas terras xavantes, nas quais seu pai e tios caçavam, mas que agora (ao menos grande parte das que correm ao largo da estrada) se resumem a enormes plantações de soja: “- Um mar de soja", segundo Divino Tserewahú. Ele nos contou também que não aconteciam muitos conflitos em torno da questão da terra entre xavantes e fazendeiros mas que, ainda em março, fariam uma ação para avaliar o avanço que um fazendeiro tem feito sobre as terras xavantes. Outra aspecto por ele relatado era a vontade de realizar um documentário sobre sua trajetória cinematográfica (que completa 20 anos no dia 16 de outubro) iniciada no projeto "Vídeo nas Aldeias". Ao chegarmos na reserva fomos recebidos na missão onde ficamos hospedados. A oficina já havia iniciado e não conseguimos chegar a tempo de seu início. Na aula que acontecia quando chegamos ao espaço, Luís (jornalista e pesquisador pela UFG) falava sobre a construção do roteiro, incentivando-os a contar narrativas divididas em 5 partes (como uma espécie de escaleta).

No dia seguinte, as atividades iniciaram-se logo cedo com o café às 7:30 da manhã. Começada a oficina, Divino pediu para que todos os alunos se apresentassem para os novos professores (no caso eu e Jota). Depois da apresentação, contei aos participantes um pouco sobre a trajetória que me levava até ali, das afinidades temáticas e da vontade de aprender e realizar processos de partilha de conhecimento. Jota também se apresentou e fez considerações muito interessantes. Junto de Luís e Paulinho Kadojeba, demos uma aula sobre aspectos teóricos do cinema (como noção de planos, enquadramentos) e na parte da tarde realizamos trabalhos práticos em campo, dividindo a sala em 5 grupos cada qual com um monitor (eu, Jota, 
Paulinho, Luís e Takumã). Depois dos registros feito pelos alunos, exibimos as gravações na sala e debatemos os resultados. Encerrada a oficina nos dirigimos ao dormitório e, depois de um breve descanso, fomos ao encontro de Takumã (kuikuro) e dos outros amigos kalapalo, na sala onde estavam alojados. Takumã nos mostrou suas recentes produções ainda não lançadas, como um filme que tratava da encenação e do teatro entre as mulheres kuikuro. Seus filmes tem uma leveza bastante peculiar, uma poética que somente um kuikuro poderia conseguir numa narrativa dentro deste contexto. Pela noite conversamos com alguns estudantes de medicina, hospedados na missão, que estavam a fazer um trabalho voluntário em aldeias xavantes e bororos da região. Durante a conversa nos relataram preocupados alguns dados de campo em relação aos indígenas referentes a questões como alcoolismo, saneamento básico e doenças sexualmente transmissíveis. Entretanto, alguns dos estudantes de medicina parecem fazer uma leitura da cultura enquanto um fenômeno estático, o que, por vezes, chega a soar preconceituoso (algo como, por exemplo, se espantar por conhecer indígenas tão "ocidentalizados" que têm carros e poucos cuidados com a saúde - no ponto de vista da medicina ocidental). A luz de uma forte influência positivista, exibem seus prognósticos pessimistas sobre a situação local. Entretanto, também preocupados com a situação (como não poderia deixar de ser), no tocante à saúde sugerimos que, se possível, poderíamos incentivar uma reflexão sobre essa questão incentivando-os a investigar a temática em suas produções audiovisuais. Para encerrar o encontro, assistimos ao filme "O dia em que a lua menstruou" do amigo Takumã que, a meu ver, pôde contribuir ainda mais com as reflexões.

Mais um dia bastante produtivo de oficina. Jota primeiro falou aos alunos sobre a importância do aprimoramento da audição e atenção em relação às paisagens sonoras durante uma realização audiovisual e depois, de forma geral, sobre diferentes formas e técnicas de captação do áudio. Ainda na parte da manhã, Luís falou sobre estratégias de investigação e pesquisa anteriores à elaboração do roteiro. Na parte da tarde, os alunos, em duplas, elaboraram temas e exercitaram possíveis soluções audiovisuais para os caminhos pensados. Ao final do exercício, diálogos muito férteis surgiram e eu os gravei. Ainda durante o almoço iniciamos uma conversa com Takumã sobre a possibilidade de que alguma das produções dos alunos lidassem com a temática da saúde. Ele recebeu muito bem a ideia e marcamos uma conversa para a noite, no alojamento, com os Kalapalos (Viola, Rangu e Kaiauta), além de nós e os estudantes de medicina. O diálogo interdisciplinar se mostrou muito fértil e todos os lados deram contribuições bastante importantes para o objetivo. Depois da conversa fizemos novamente uma sessão de cinema (desta vez com a presença de Takumã, autor do filme). A exibição dos filmes tem se tornado um evento a parte no alojamento em Sangradouro. Deste modo, nos aproximamos através dos filmes e de Takumã, Viola, Kaiauta e Rangu, do universo xinguano kuikuro e kalapalo. 


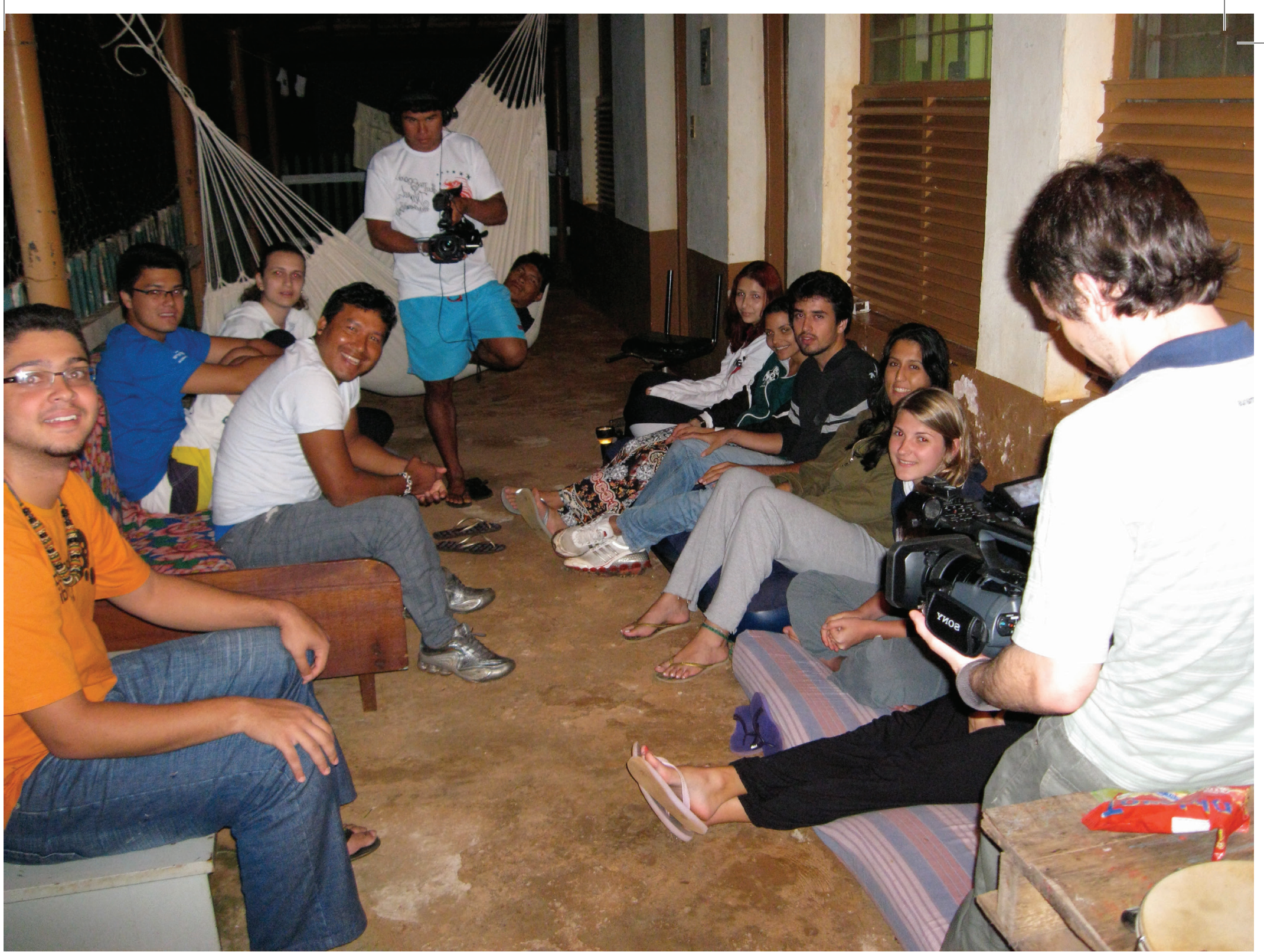

Foto 4 Encontro dos Indígenas kuikuro e kalapalo com professores de audiovisual e estudantes de medicina (foto Jota Beck)

$\mathrm{Na}$ manhã seguinte dividimos a sala em 5 grupos misturando ao máximo as 4 etnias participantes. O resto da manhã e a tarde foram reservados a orientação das equipes que já começam a desenvolver trabalhos de campo. A experiência tem sido muito engrandecedora, sobretudo, pelo aprendizado e partilha de conhecimentos com os alunos. Os temas a serem tratados nos filmes, por escolha dos grupos, foram: 1. Artesanato xavante, 2. Saúde, 3. Poluição, 4. Alimentação, 5. Conflitos internos na aldeia. O grupo 5 (orientado por Takumã), em especial, batizou-se com o sugestivo nome de "Auwé Tsiwadzari", que significa, em xavante, algo como "Índio misturado". Uma ideia bastante criativa já que esse grupo, particularmente, reuniu ao menos um integrante de cada uma das 4 etnias participantes. Alguns dos grupos, mais ansiosos, a despeito do cronograma dedicado à pesquisa para o roteiro, decidiram já iniciar as filmagens, enquanto outros ainda continuaram apenas pesquisando a temática. O grupo Auwé Tsiwadzari, monitorado por Takumã, iniciou quase de imediato as filmagens, dado que, no grupo, já existia uma familiaridade dos integrantes com a linguagem audiovisual. Pela noite, no alojamento, recebemos novamente a visita dos nossos amigos xinguanos. Jota, como de costume antevendo a possibilidade de diálogos musicais, havia trazido para a viagem um pandeiro e duas flautas andinas. Takumã, por sua vez, havia se encantado com o pandeiro desde a primeira visita, a 
despeito da dificuldade em tocá-lo. Jota presenteou-o com o instrumento e aproveitou para pedirlhe, mirando uma visita futura, um instrumento de sua etnia. Takumã passou a batuca-lo sem conseguir produzir um ritmo específico, porém com a continuidade da brincadeira começamos todos, ainda que desajeitados, a orquestrar uma desafinada banda multicultural. Quando cessado o som perguntei a Takumã o nome que ele daria para a banda, ao passo que ele sugerira "Koluta" (típica flauta kuikuro), graças a onipresença do pandeiro na brincadeira incorporamos a palavra "batuca" e, por fim, por sugestão de Luíz, "os trutas" (amigos) também entraram na brincadeira, originando o insólito conjunto "Koluta, batuca e os trutas", um desencontro musical sincrético vivenciado nestes dias de Sangradouro.

Conhecemos a aldeia xavante (mais próxima à missão) no terceiro dia de trabalho. Como todas as atividades da oficina, da manhã até o fim da tarde, acontecem na escola da missão, ainda não havíamos conseguido nos deslocar para visitar a aldeia. Nossa ida à aldeia fazia parte da orientação aos grupos que começaram as filmagens de seus trabalhos. Nestas oportunidades, como viemos a saber depois, a comunidade xavante de Sangradouro aceita bem a presença de indígenas e não-indígenas realizando registros audiovisuais. O lugar, de fato,

Foto 5. Koluta, batuca e os trutas. (foto: Luíz Eduardo Silva)

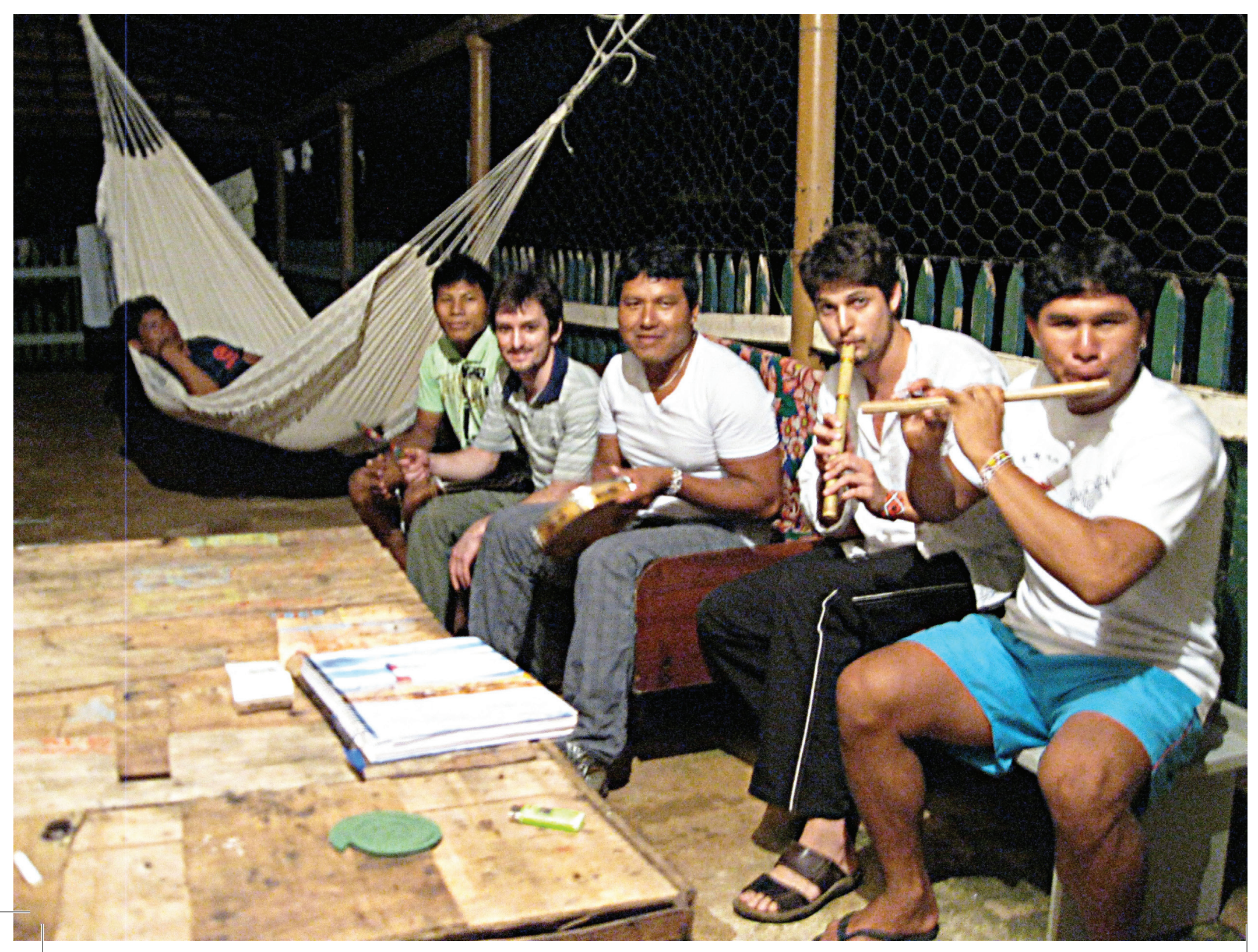




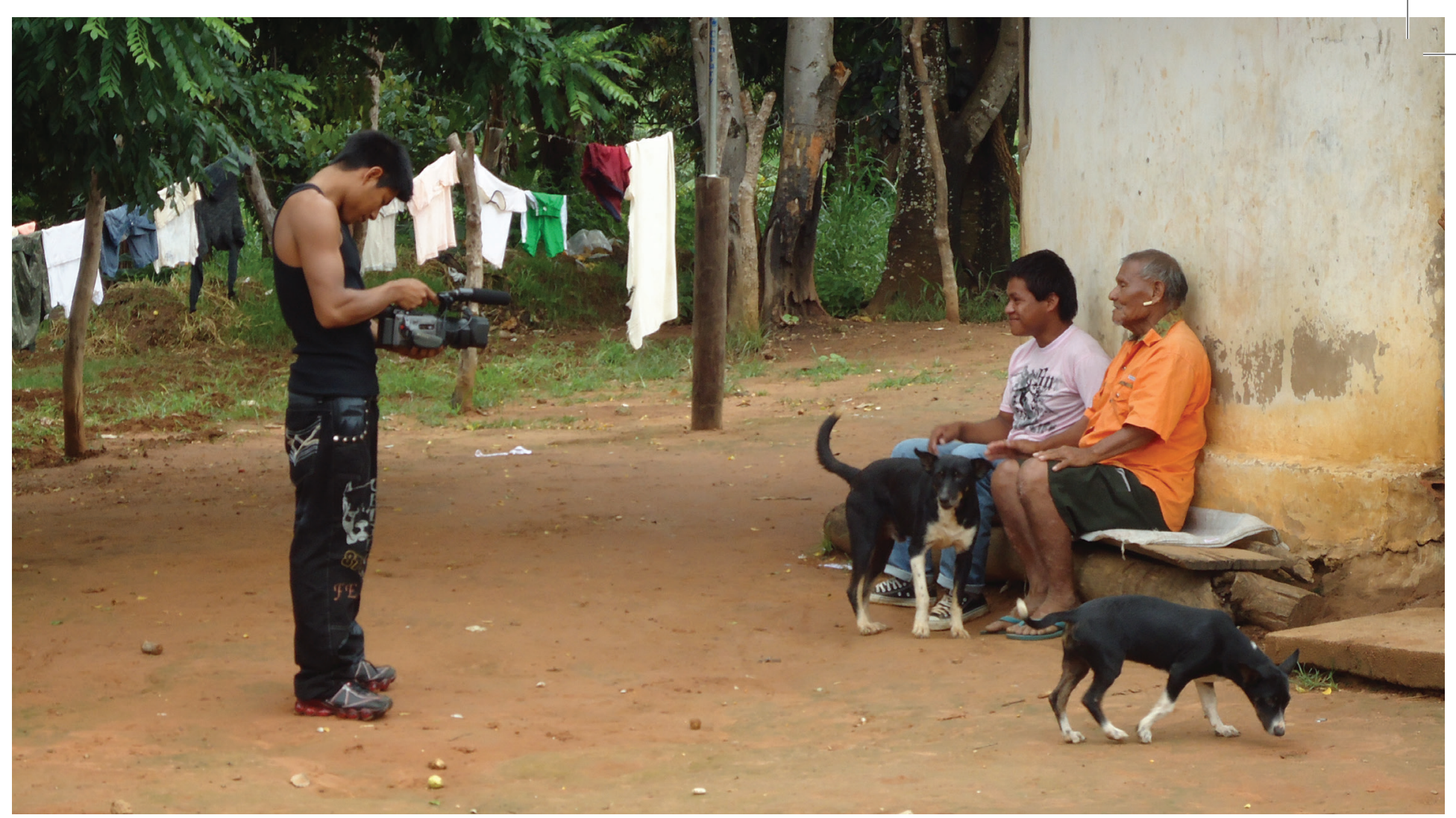

Foto 6. Rangu Kalapalo registrando cenas para o filme sobre a alimentação xavante. (foto: Caio Lazaneo)

nos permite observar uma acelerada introdução de aspectos de culturas não-indígenas num contexto bastante singular. O mesmo contato que proporcionou ferramentas digitais de registro que possibilitam a realização dos incríveis filmes que conhecemos (assim como os que poderão vir a realizar) é também o que proporcionou a entrada desenfreada do álcool, dos maus hábitos alimentares (introdução acentuada do sal e do açúcar através dos alimentos industrializados), entre outros agravantes, o que sugere um cenário de enorme tensão. Entretanto, encarar o conceito de "cultura" sob qualquer pressuposto purista, me parece, nos levaria a um equívoco. A cultura, enquanto processo, sempre foi possível enquanto tal, graças a hibridismos inerentes a uma dinâmica sincrética, par excelence. Os próprios interlocutores indígenas, neste contexto, costumam explorar estes horizontes de tensão como aporte para questões e reflexões no produto audiovisual pertinentes aos seus universos culturais. Os temas escolhidos pelos grupos do curso, por exemplo, têm relação direta com os problemas não só inerentes ao contexto xavante (poluição, saúde, alimentação, etc), mas que constituem um esboço do que esse intenso processo de trocas proporcionou, tanto no que concerne às problemáticas como às reflexões.

$\mathrm{Na}$ aldeia, podemos notar com frequência (e recorrentemente nas falas de interlocutores da comunidade) que o excesso de lixo oriundo dos alimentos industrializados (introduzidos recentemente nas práticas cotidianas, com maior ênfase a partir da década de 90) acarretam frequentes problemas em relação à saúde. Entretanto, é interessante observar que ao passo que intensificam-se esse problemas, intensificam-se, também, as reflexões da comunidade, seja em longas rodas de conversa, ou nas demandas políticas negociadas pelas lideranças, bem como no singelo exercício audiovisual realizado por seus jovens. Tal como "arcos", porém munidas de uma faceta digital, as filmadoras adentram a comunidade, valorizando os diálogos fílmicos possíveis, e atiram suas flechas fílmicas contra as ameaças tantas vezes intangíveis.

Pela noite, um tanto entediados com a monotonia do alojamento, decidimos (eu, Jota e Luíz) voltar à aldeia a procura de algum xavante que pudesse nos emprestar um violão, por mais 
estranho que isso pudesse parecer. Na única casa onde nos haviam apontado a possibilidade de que alguém possuísse o instrumento, isso não se confirmou, já que quem o tinha o havia deixado na cidade mais próxima. A experiência de voltar a noite para a aldeia, ao menos para mim, fora motivada pelo encantamento de ter conhecido o lugar durante o dia. Na volta, acabamos encontrando Sérgio, um aluno da oficina, e perguntamos a ele onde poderíamos conseguir o instrumento. Ele nos informou de que uma madre salesiana da missão provavelmente tinha um violão, o que se confirmou pouco depois quando o conseguimos emprestar, que veio a alegrar musicalmente as calmas noite de Sangradouro.

Mesmo no sábado, as atividades da oficina prosseguiram em ritmo normal e passamos a manhã e a tarde assistindo o material já registrado pelos grupos e realizando um amplo diálogo com todos os participantes sobre o desenvolvimento dos trabalhos, tanto no aspecto técnico - focando desde o manuseio da câmera, noções de enquadramento, som e iluminação - quanto no aspecto conceitual - mais relacionado com a forma com que cada grupo lidou com cada temática de acordo com os roteiros. O exercício produziu resultados muito interessantes e questões complexas foram levantadas. Alguns grupos decidiram refilmar cenas que foram apontadas com potencial de melhora.

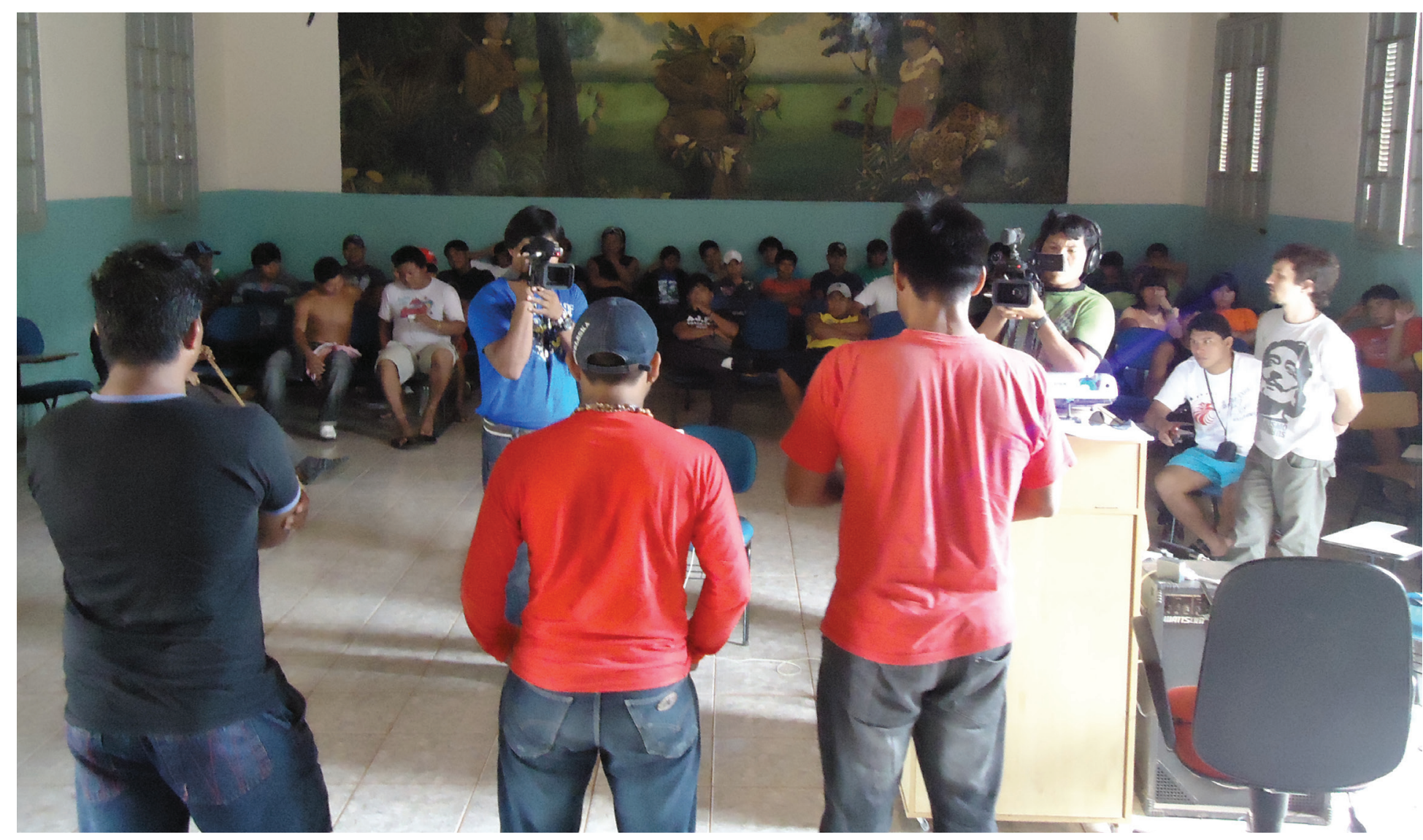




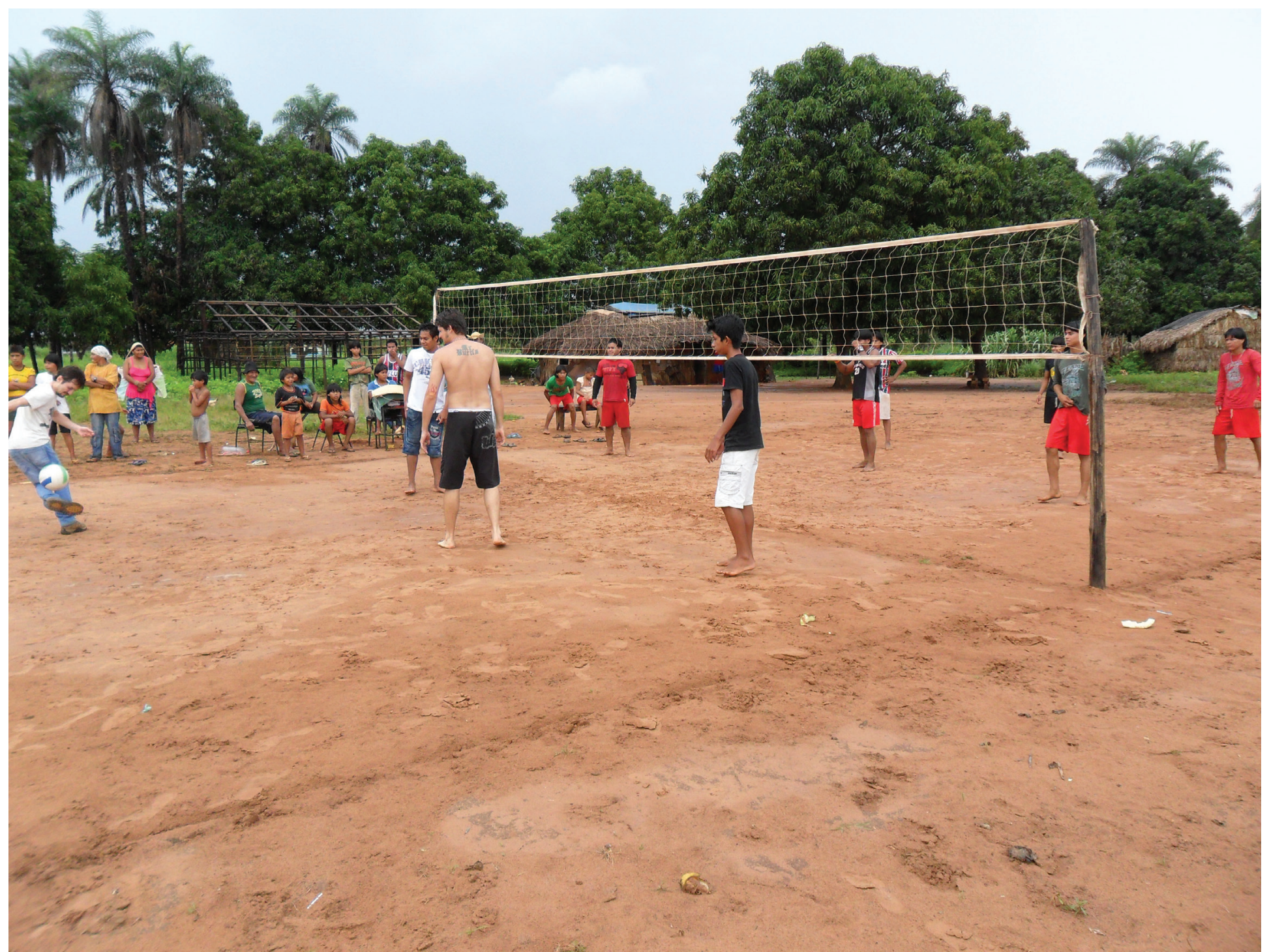

Foto 8. Xavantes de Öwawe x Participantes da oficina. Vôlei muti-étnico (foto: Kaiautá Kalapalo)

Minha relação com Divino segue muito boa. Ele é um sujeito muito cativante, engraçado e extrovertido. Não é de se admirar que em pouco tempo já pareçamos amigos de longa data. Pela noite, no alojamento, a banda "Koluta, batuca e os trutas" apareceu mais uma vez. Batuques desritmados, cantos improvisados e alegria partilhada. "Em meio a uma mata que se perde, meu amigo Kuikuro é um high-tech”, anunciava um dos versos improvisados durante a noite.

O domingo fora seguramente um dos mais insólitos que já vivenciei. Logo pela manhã partimos em 20 pessoas (participantes da oficina) - nos dividindo entre 7 pessoas na cabine e 13 na carroceria de uma antiga Toyota empresta pelos salesianos - rumo a aldeia Öwawe (Água Grande), não muito distante de Sangradouro (aproximadamente $60 \mathrm{~km}$ ) mas que, entretanto, leva-se aproximadamente duas horas para lá chegar. A viagem acompanhava uma expectativa enorme, pois sabíamos que aos fundos da aldeia passa o rio Cristalinas no encontro com o Rio 
aqui. A oportunidade de ter tido minha primeira experiência como professor, em meio a este singular contexto que mistura indígenas de 4 diferentes etnias, seguramente me proporcionara um aprendizado sem igual. Tenho feito amizades nestes dias que tenho certeza, levarei para sempre comigo, assim como os inesquecíveis dias de Sangradouro. Nos exercícios de decupagem dos grupos - reflexo do processo - a dinâmica tem sido muito boa. Acredito que, apesar do pouco tempo, bons exercícios fílmicos brotarão da experiência e, ainda mais importante, formas instigantes de pensar o audiovisual não só sob a perspectiva da registro a partir de realizadores indígenas como também de possibilidades partilhadas. Essa vivencia audiovisual, corporal, musical, tem mostrado o quão fértil pode ser o caminho de um cinema partilhado, ferramenta poético-política praticada junto de meus novos amigos. Algo que remete à explicação sobre a forma quase militar com que o amigo bororo Paulinho Kadojeba empunhava sua câmera (em uma foto que bati e depois mostrei a ele) que, segundo ele, demonstrava seu estado de alerta frente a seu "campo de batalha". Excertos de Sangradouro, lugar para mim tão extraordinário, onde experimento incógnitas conceituais desdobrando-se em múltiplas possibilidades. O corpo exausto ao fim dos dias tem permitido ao espírito poucos devaneios durante meus descansos, ainda que acordado eu frequentemente o faça.

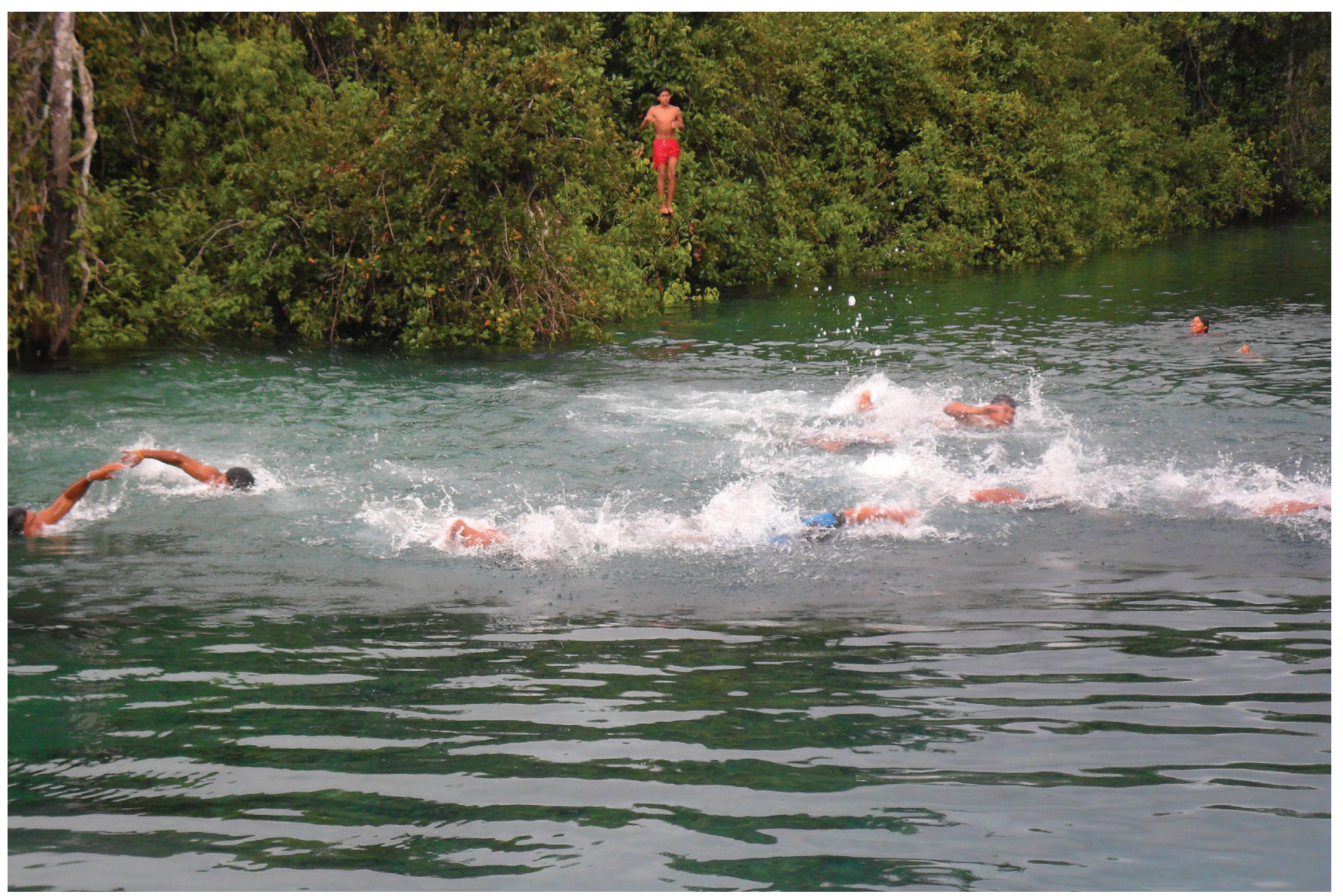

Foto 10. Jovens da aldeia Öwawe divertindo-se com brincadeiras e competições inventadas na hora no Rio Cristalina (foto: Kaiauta Kalapalo) 


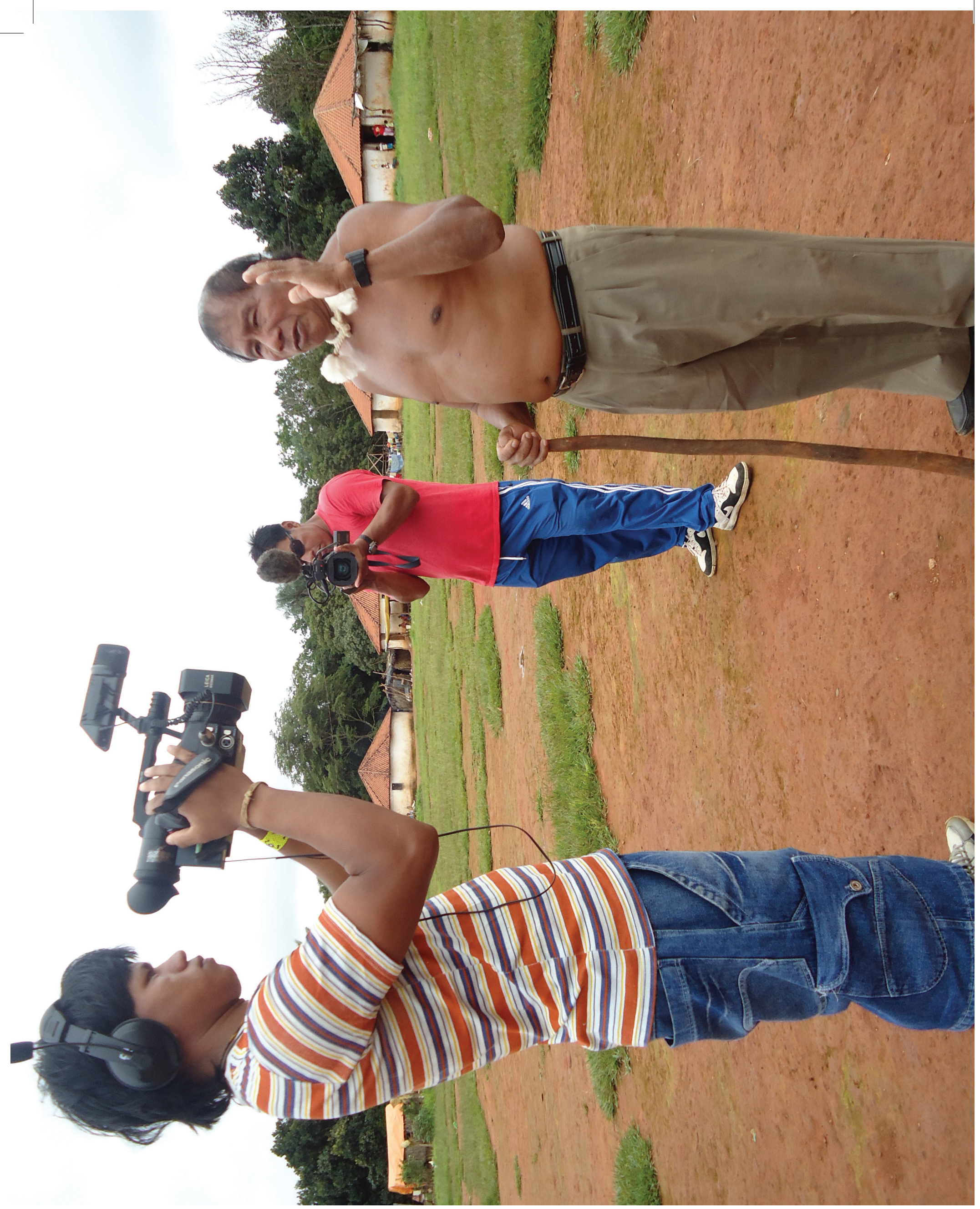

Foto 11. O bororo Paulinho Ecerae Kadojeba, ao fundo, "empunha" sua câmera e filma - além da câmera que fotografa - o professor de artesanato Casimiro Weté. No primeiro plano, o xavante Pascoalino Tseremadzawe'Raiwi'a também o filma. (foto: Caio Lazaneo) 
$\mathrm{Na}$ etapa da decupagem e edição alguns grupos, naturalmente, seguem mais avançados do que outros. O grupo 05, monitorado por Takumã, esteve bastante adiantado em relação aos outros. A despeito de sua extrema habilidade com a linguagem audiovisual, sua didática não me parece tão fértil, o que faz com que ele centralize mais o processo (e, desta forma, naturalmente o acelere). $\mathrm{O}$ evento chegou a uma etapa bastante cansativa e tenho encontrado dificuldades para registrar os registros e experiências que havia previsto no planejamento antes da viagem. Após a janta, os alunos geralmente também estão exaustos. A nós, praticamente resta apenas retornar ao alojamento, refletir sobre o que se passou durante o dia e descansar.

O terceiro dia de edição seguiu em ritmo acelerado. O grupo por mim coordenado teve dificuldades em executar o roteiro sobre o tema escolhido (conflito na aldeia) e na decupagem percebemos que seria necessária a captação de novas imagens. Esse tema, em especial, é bastante delicado. Como me foi explicado nos diálogos com os xavantes, existe um conflito acentuado entre duas lideranças (de um lado, Alexandre Tsipatsé, pai de Divino, e do outro Domingos), que ameaça inclusive uma cisão definitiva da aldeia. A ideia a princípio seria investigar as causas deste conflito e ouvir as diferentes versões, entretanto, acredito eu, por falta de experiência e/ou até mesmo por inibição, o grupo não conseguiu executar o roteiro e teve de transformar a ideia inicial em uma introdução a problemas do cotidiano xavante de Sangradouro, como a questão do lixo, a influência cultural dos waradzu (branco), etc.

O processo de edição tornou ainda mais próximo o diálogo e afeto principalmente com os xavantes (já que no grupo apenas há integrantes da etnia). Hoje recebi do amigo José Carlos Tsipatsé um pulseira de imbira, segundo ele, como sinal de amizade. Pela tarde realizei com Jota uma longa e emocionante entrevista filmada com Paulinho Kadojeba, que nos relatou sua iniciação no audiovisual, lembranças de sua infância e, até mesmo, aspectos musicais da cultura bororo.

A proximidade da partida traz a tona uma série de reflexões. Por um lado sinto que pertenço a esse lugar e a esse povo de algum modo e, de outro, sinto que sairei com uma incontrolável vontade de conhecer novos lugares e culturas. A dinâmica da oficina de audiovisual tem sido muito gratificante e os múltiplos olhares em formação, acentuam ainda mais a incrível abertura do jogo. Já começa a me apertar a garganta um nó de saudade que sei que sentirei destes dias de Tsö'rehipãrí. O ritmo intenso do trabalho de edição tem sido exaustivo muito embora divertido. $\mathrm{O}$ xavante me parece um povo muito alegre e festivo e com um humor bastante peculiar. As demonstrações de afeto continuam por parte dos alunos. Pela tarde, o amigo 

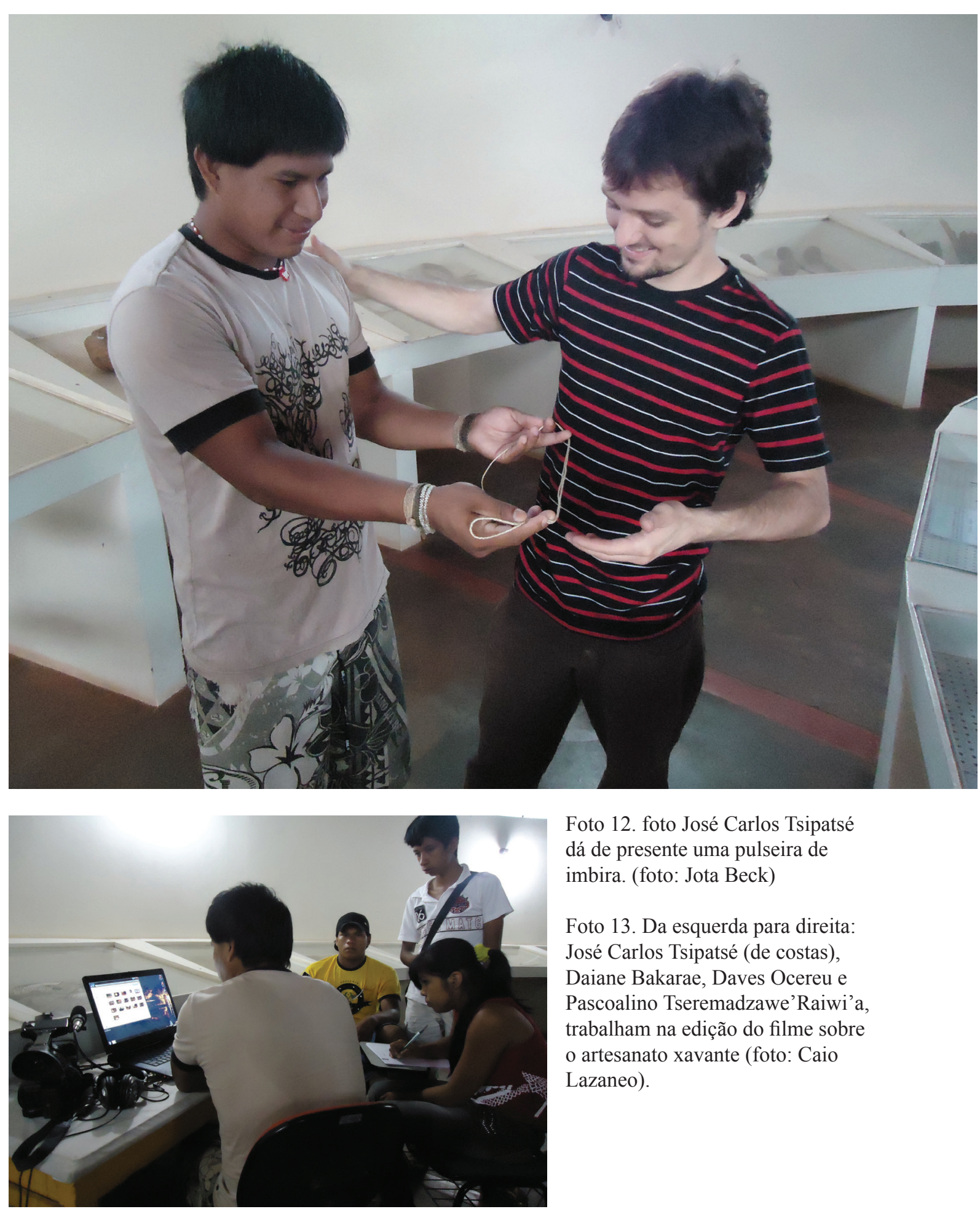

Foto 12. foto José Carlos Tsipatsé dá de presente uma pulseira de imbira. (foto: Jota Beck)

Foto 13. Da esquerda para direita: José Carlos Tsipatsé (de costas), Daiane Bakarae, Daves Ocereu e Pascoalino Tseremadzawe'Raiwi'a, trabalham na edição do filme sobre o artesanato xavante (foto: Caio Lazaneo).

Eliseu Tserenhowamre também me presenteou com uma pulseira de imbira. O grupo que estou acompanhando na edição começou a legendar as fala do xavante para o português. A expectativa é que todos os grupos apresentem amanhã uma primeira versão de seus filmes. Um misto de alegria, ansiedade e saudade tem me feito companhia durante a noite quando retorno ao alojamento.

Os grupos finalizam os filmes em ritmo acelerado no Museu Comunitário (utilizado como base nessa etapa). Bruno Fiorese (estudante da UFG) chegou ontem para contribuir com a etapa da edição. No museu nos dividimos em três ilhas coordenadas por mim, Jota e Bruno. Paralelo à edição, me comprometi a criar a identidade visual do evento e as vinhetas para os filmes, tarefa que por conta do pouco tempo tem me feito ficar, com alguma frequência, sem as "misturas" (de carne, frango, etc) nos horários de almoço e janta (já que os pratos são servidos por ordem de chegada). Ontem mesmo, consegui jantar apenas arroz.

Pela manhã Divino reuniu toda a sala para que decidíssemos juntos o nome do evento. A 
maioria optou por batizá-lo como "A’uwé Tsiwadzari”, que na língua xavante quer dizer "índio misturado", além de "Tetsualüko" e "Boeenogododu", palavras com o mesmo significado nas línguas kuikuro e bororo respectivamente. Assim, definiu-se também que o primeiro nome a aparecer será sempre no idioma da etnia-sede do curso. Pela noite exibimos a primeira versão dos filmes e novos e interessantes diálogos surgiram. A sensação de assistirem pela primeira vez a exibição de uma produção própria os deixou muito contentes. Lembrarei sempre com carinho da fala do amigo Viola Kalapalo, em português não muito fluente, sobre a emoção que quase o fizera chorar ao ao ver projetado o filme que ajudara a construir.

Nova projeção dos filmes na sala de aula nessa manhã. Dessa vez os alunos receberam convidados da comunidade xavante assim como o padre Luíz Leal. É no mínimo curioso notar um processo de "descolonização" do saber que me parece acontecer em situações como essas. Os salesianos que sempre foram os provedores de uma "educação" cristianizada (e monológica!) aos xavantes, passam a, de certo modo, serem objetos de um processo de reflexão a partir dos próprios indígenas. A fala do padre Leal era acompanhada por pelo menos duas câmeras operadas por indígenas participantes do evento. Eis a inversão de papéis: Ainda que a autoridade clerical, através do discurso cristão, aponte caminhos doutrinadores, é o indígena quem, a partir do processo de montagem, poderá desenvolver sub-repticiamente sua reflexão, algo que seria, a priori, dificilmente possível em uma matriz textual, sobretudo pela falta de identificação de

Foto 14. Viola Kalapalo filma Valeriano Rãiwi’a Werehité durante conversa após exibição de filmes (foto: Caio Lazaneo).

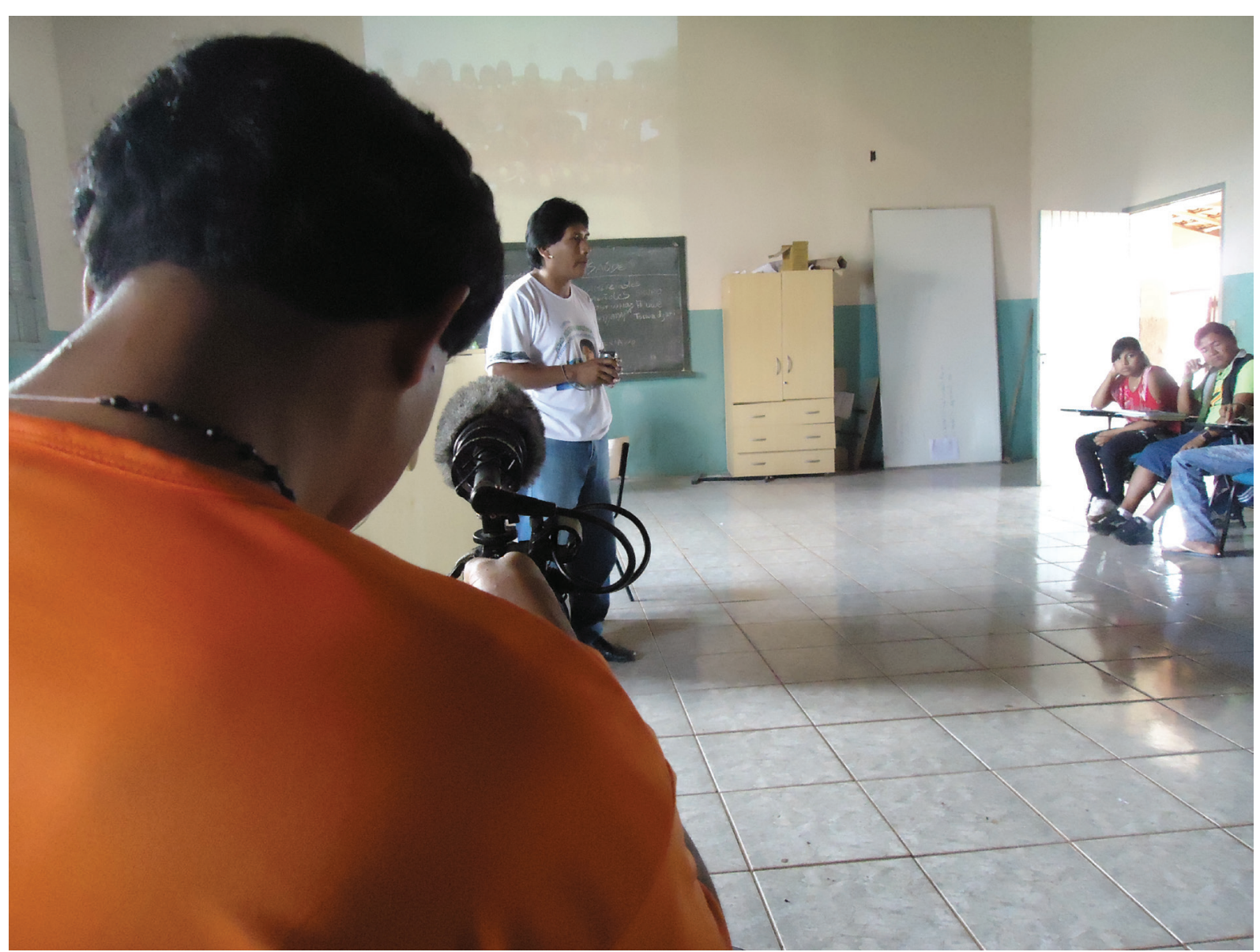




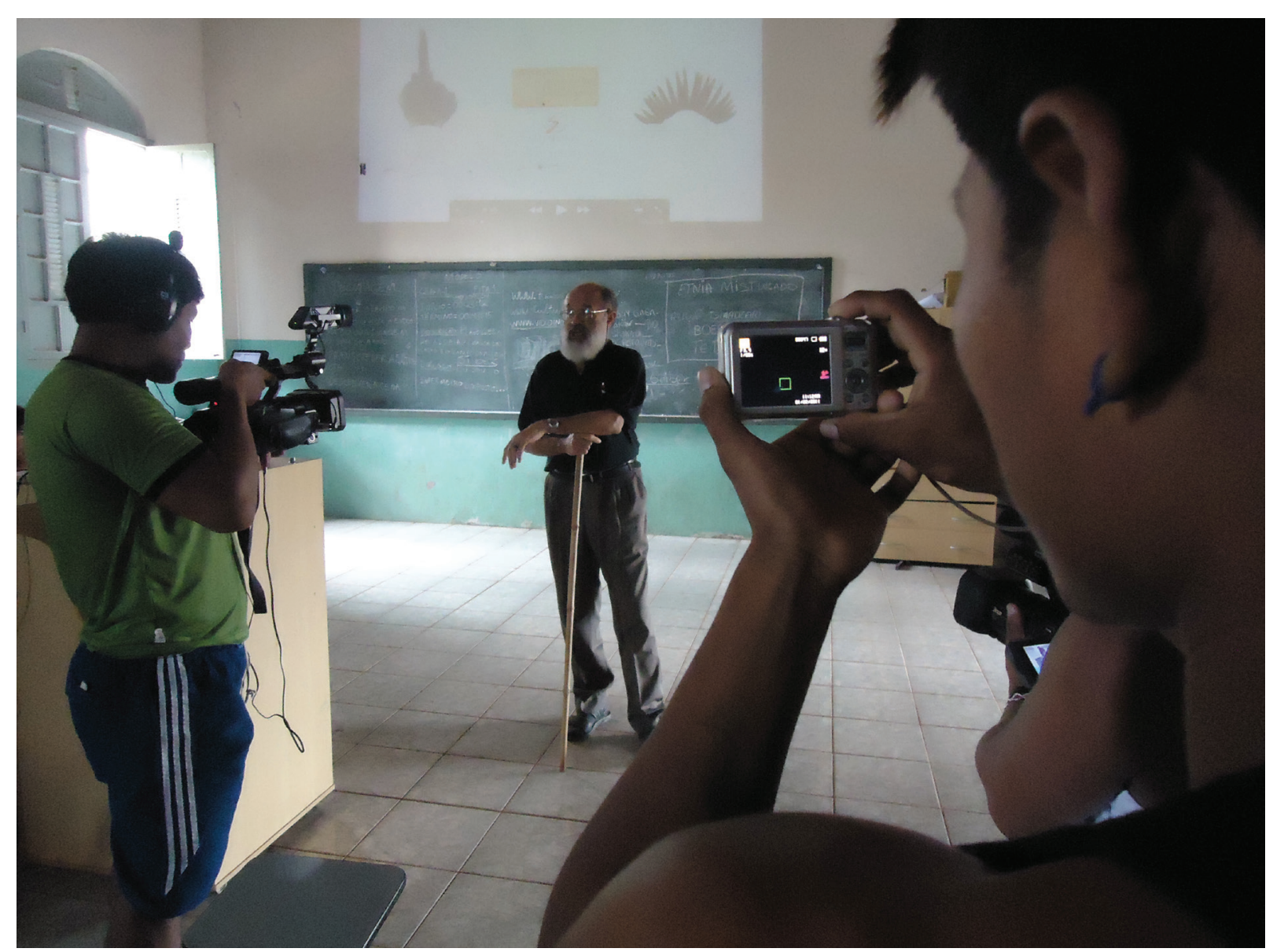

Foto 15. Padre Luíz Leal é filmado por Kaiauta Kalapalo e fotografado por Rangu Kalapalo (foto: Caio Lazaneo).

culturas de tradição oral com o texto, o que caracteriza também uma certa marginalização na formação de autores indígenas (vide, por exemplo, a vasta literatura sobre o cotidiano, rituais, festas, etc, dos xavantes e bororos escritas a partir de autores salesianos).

A exibição, desta vez, fora ainda mais fértil já que ao final dos filmes cada grupo falava sobre sua experiência de realização, assim como respondia à perguntas feitas pelo público. A sessão fora bastante simbólica já que boa parte dos filmes tratava de temáticas relacionadas à problemas cotidianos dos xavantes de Sangradouro, o que despertou algumas reflexões no discurso do padre. Nele Leal, dentre outros assuntos, enfatizou (o que para mim pareceu uma descabida comparação) que na Suíça "quem atira lixo ao chão recebe uma multa". Como quem recomenda aos indígenas um padrão de comportamento, esquecendo-se de que o "lixo" é um conceito atrelado ao desenvolvimento de uma sociedade ocidental capitalista, algo ainda nebuloso para uma comunidade em que o contato com esse contexto é ainda muito recente. De modo geral, me pareceu que o conteúdo dos filmes pegara de surpresa tanto o padre quanto as pessoas da comunidade. Algo que é, para mim, muito positivo e que esboça o quanto essa experiência audiovisual pôde contribuir significativamente para uma comunidade que se abriu para um processo fílmico reflexivo, característica tantas vezes exercitada por Divino e acentuadamente socializada nas dinâmicas das oficinas.

Após o almoço encerrou-se oficialmente o evento "A'uwé Tsiwadzari: Curso de Formação de Cineastas Indígenas”. Com um clima de saudade os participantes das outras etnias começaram a ir embora. Luíz e Bruno, nossos amigos de Goiânia, também partiram pela tarde e de imediato nos bateu a estranha sensação da ausência de pessoas que tanto convivemos nos últimos dias. Com o término do curso passaremos a fazer as refeições, até o dia de nossa partida, no alojamento da missão salesiana. 
Apesar do término das atividades do curso, acordamos logo cedo no domingo para um experiência diferente. Fomos eu e Jota, assistir à missa na igreja da missão. O que chama atenção no evento (exclusivamente o dominical) são os cânticos cristãos traduzidos para o xavante e que são entoados, pelos indígenas presentes, ao longo de todo culto. Um misto de curiosidade e estranheza acompanha a cena. A (oni)presença salesiana na aldeia (também em signos como a enorme cruz presente no pátio central), a mim, é objeto de reflexão constante. Quanto dessa presença, de fato, impõe uma (mono)lógica cristã ao cotidiano xavante e quanto seria ela também influenciada? É certo que existem (nos dois lados em jogo) astúcias e estratégias nem sempre evidentes, mas que permeiam o cotidiano destas duas distintas comunidades. Um exemplo evidente é a estátua do Cristo crucificado na igreja que traz no pescoço uma gravata xavante, com um claro objetivo de sugerir uma identificação. Recordo de imediato de uma fala do padre Leal, no filme de Divino sobre Sangradouro, em que comenta ser uma característica fundamental ao povo xavante sua capacidade de organização estratégica. Característica essa que, me parece, sugere uma condição negociada onde o que está em jogo nem sempre é uma dominação, seja ela política, territorial ou ideológica, mas espaços onde o xavante compreenda uma necessidade de articulação, o que, na compreensão de Michel De Certeau, estaria mais associado à tática do que propriamente à estratégia. Assim se sucedera com a aproximação, na década de 50, dos xavantes de Parabubure até a região de Sangradouro, conduzidos por Tsereptsé (avô de Divino). Os mesmos sofriam de fome e de doenças e, no caminho, encontraram uma missão salesiana. Seria exagero sugerir que, neste caso singular, os missionários teriam sido, a princípio, "xavantizados" antes dos xavantes "evangelizados"?

Voltando ao culto, no "hino" de encerramento alguns xavantes executam também a coreografia corporal característica de suas danças circulares. Na saída da igreja reconheço lideranças da comunidade que, a mim, lembram eméritos diplomatas ainda em pleno exercício. Lembro de algumas das vezes que em tom de brincadeira, tanto eu quanto Jota, repetíamos para Divino (imitando a fala do padre no filme): “O xavante é um povo estratégico!”. Naturalmente, a situação despertava um riso espontâneo que ri tanto da carnavalização da figura clerical,

Foto 16. Plateia da aldeia assiste a projeção dos filmes (foto: Caio Lazaneo)

Foto 17. Grupos falam sobre o processo de realização dos filmes. (foto: Caio Lazaneo)
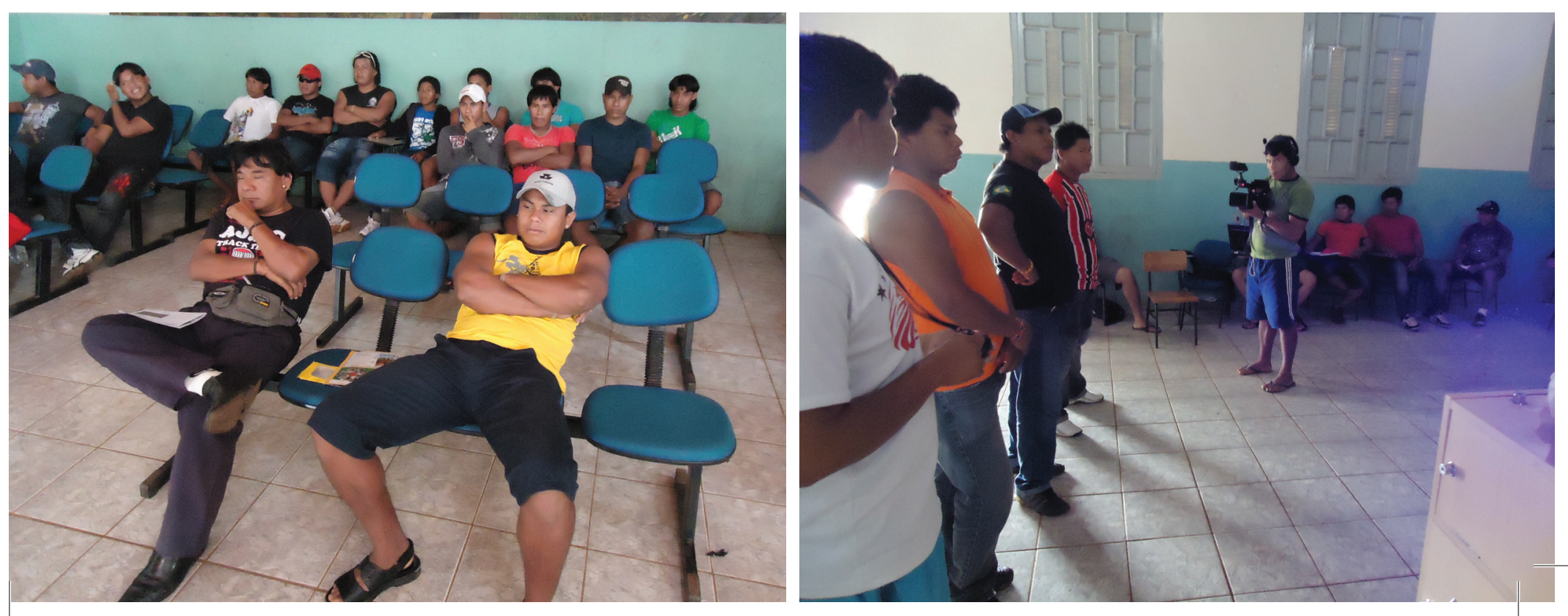
quanto da certeza cotidiana da veracidade da frase.

Nas refeições que temos feito em companhia do padre Luiz Leal e do padre Benito, uma preocupação tem sido por eles constantemente evocada: O recente conflito de origem política instaurado na aldeia. Leal presenciara algo semelhante em São Marcos, entretanto lá o conflito fora de ordem religiosa. A preocupação se dá principalmente porque quando o impasse atinge seu ápice, uma das partes tende a abandonar a aldeia incendiando suas casas e migrando para uma nova aldeia, como acontecera em São Marcos. Tenho a esperança, principalmente pelas minhas conversas com Divino, de que isso não acontecerá em Tsö'rehipãri. É comum ele citar o desejo de investigar o conflito realizando um filme. Creio, assim como ele, que o audiovisual pode de alguma maneira contribuir como uma peça fundamental nesse jogo.

Conforme combinado, pela noite exibimos os filmes na aldeia. Antes da exibição, porém, passamos por uma das experiências que, dentre tantas, fora para mim das mais significativas. No centro da aldeia, próximo de onde estávamos, havia um círculo de anciãos xavantes que conversavam tranquilamente em seu idioma. Divino se aproximou e, solicitando permissão para falar, começou um discurso sobre o qual, até então, não sabíamos do que se tratava. Ao terminar, convidou-nos para adentrar à roda e conta-los sobre nossa estada na aldeia, assim como sobre a experiência da oficina. De surpresa, falei sobre a gratidão para com a comunidade que tão bem nos havia acolhido e agradeci pela oportunidade de todo aprendizado partilhado. Jota também o fez. Quando terminamos de falar, Divino traduziu nossas falas e, imediatamente, alguns dos anciãos se levantaram e vieram em fila nos cumprimentar pelo que havíamos feito pela comunidade. Nessa hora, inevitavelmente, uma lágrima contida escorreu em meus olhos. A certeza de um bom retorno estava assegurada. O gesto de uma comunidade, através de seus anciões (estágio máximo do conhecimento) que aprova e agradece por um trabalho é algo muito emocionante e sincero.

A projeção no começo da noite reuniu muitas pessoas e família que deixavam suas casas para assistir o que os alunos xavantes, bororos, kuikuros e kalapalos haviam produzido durante as 2 semanas do curso em Sangradouro e que, até então, não entendiam muito bem para o que serviria. Esse retorno foi a oportunidade de mais um momento reflexivo, qual seja, a comunidade se vendo apresentada desta vez pelos olhares dos dahöibari waté (cineastas iniciantes) xavantes e de outras etnias. 


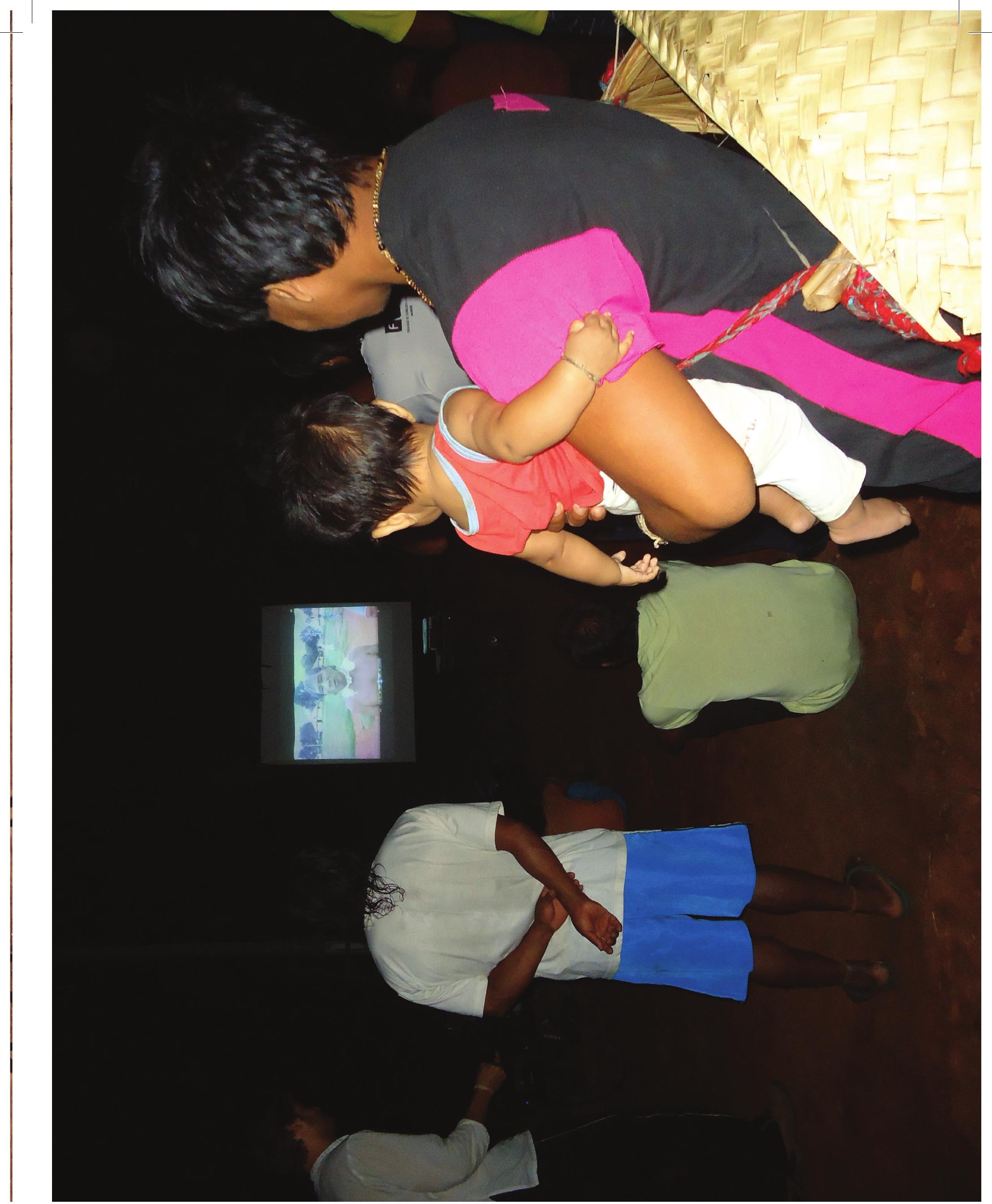

Foto 20. José Carlos Tsipatsé (de costas no primeiro plano) segura seu filho no colo e assiste a seu próprio filme. (foto: Caio Lazaneo) 
Encontrei durante a exibição meu amigo José Carlos Tsipatsé que, coincidentemente, assistia todo orgulhoso seu filme sobre o artesanato xavante carregando seu filho no colo.

Ao final da exibição nos reunimos (eu, Jota, Divino, Fábio João e José Marinoni) na casa de Geremias (irmão de Divino) para comer peixe assado e comemorar a alegria partilhada. Com o céu mais estrelado dos dias de Tsö'rehipãri, nos despedimos de nossos amigos. Pela manhã é a hora de encarar a viagem de volta, passando pelo estranhamento de deixar um lugar já tão familiar e ao mesmo tempo distante - lar de tantos novos amigos - que nos lança de encontro a dúvidas e surpresas sem-fim. Obrigado Tsö’rehipãri!

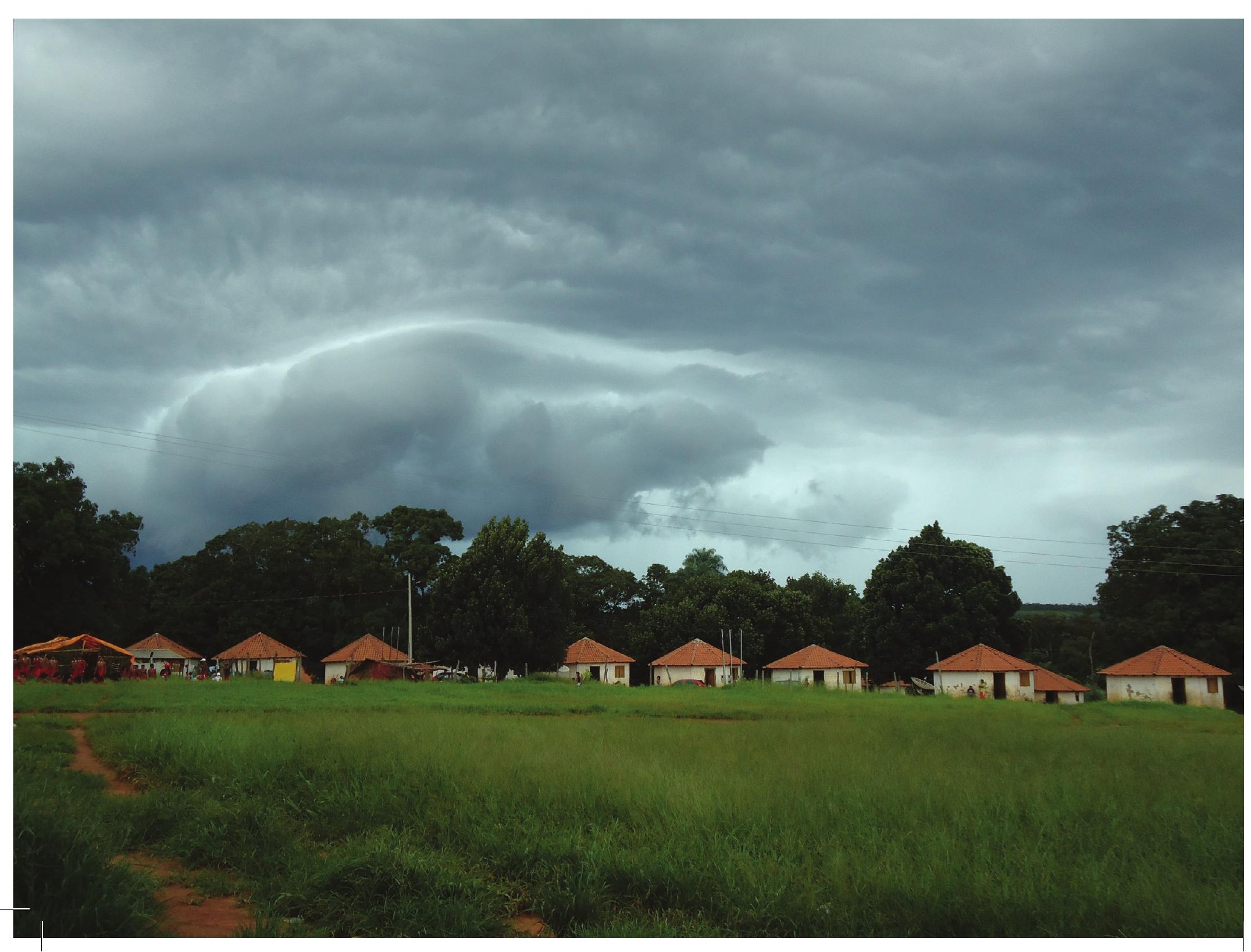




\subsection{Partilha II: Aldeia Fontoura - Ritual Hetohokã Karajá}

O segundo percurso envolvendo a equipe do CEDIPP (Centro de Comunicação Digital e Pesquisa Partilhada) da ECA-USP - através dos integrantes Caio Lazaneo, Divino Tserewahú, Juanahú Karajá e Paulinho Kadojeba - em atividades audiovisuais em comunidades indígenas, aconteceu durante o registro do ritual karajá Hetohokã (de 04 a 10 de março de 2011). A proposta da produção partilhada consistiu, a princípio, no trabalho de orientação de Juanahú Karajá feito por Divino Tserewahú e Paulinho Kadojeba (cineastas indígenas com maior experiência), além de mim. Pela primeira vez, um indígena karajá pretendia realizar um filme sobre o ritual de iniciação Hetohokã, algo até então somente realizado por toris (não indígenas). Juanahú já possuía alguma vivência com a linguagem audiovisual através da participação em pequenos cursos como a oficina "Vídeo índio Brasil", onde conhecera Divino e Paulinho. Entretanto, faltavam-lhe maiores noções de roteiro, estrutura narrativa, montagem, entre outros aspectos, visando a construção de um produto audiovisual de maior duração (média ou longa metragem). Por sua vez, mais do que qualquer antropólogo, etnógrafo ou pesquisador, Juanahú (a partir da perspectiva de um karajá imerso em sua cultura) possui uma enorme compreensão dos códigos e particularidades inerentes ao ritual, além da aceitação da comunidade que compreende e respeita a importância de seu trabalho. Esses dois eixos, de um lado o referencial técnicoteórico da linguagem audiovisual que tanto eu, Divino e Paulinho pudemos oferecer, e do outro, o extremo conhecimento da cultura karajá imanente à Juanahú, consistiram a estrutura da produção partilhada.

Nova viagem, novas partilhas. No roteiro inicial, o combinado seria encontrar Divino em Sangradouro e Paulinho em Barra do Garças. A viagem de ônibus (de Cuiabá à Sangradouro) foi muito exaustiva por conta das inúmeras paradas e do longo trajeto, por vezes em estradas que não inspiram muita confiança, abarrotadas de caminhões que fazem o escoamento da soja, o mar verde da monocultura mato-grossense.

A alegria do trajeto se deu no reencontro com os amigos. Primeiro Divino, na rápida passagem por Tsö'rehipãri (Sangradouro), que, bastante empolgado, entrou perguntando por mim no ônibus, enquanto eu acordava de um dos tantos sonos na estrada, e quando notei ele me convocava para descer. O xavante José Marinoni Tsõpré, como fui saber depois, fazia aniversário naquela data, e aguardava junto de Divino a chegada do ônibus. Eu desci rapidamente para dar um abraço em José, que ficou bastante emocionado. A viagem seguiu com muitas prosas com Divino até chegarmos, por volta das 19h, em Barra do Garças e encontrarmos Paulinho. Dessa maneira completou-se o trio que, junto de Juanahú (que nos aguarda em São Félix do Araguaia), irá filmar o ritual Hetohokã. Chegamos em São Félix do Araguaia às 11 da manhã do dia 04/03, 24 horas depois que saí de Cuiabá. Juanahú veio ao nosso encontro na rodoviária 
e fizemos um breve passeio pela pequena, mas já encantadora, cidade, cujo tamanho enorme do rio Araguaia contrasta com sua rusticidade e proporção. Após pouco tempo pude notar a popularidade de Juanahú pelo local que, por onde passa, cumprimenta comerciantes, autoridades políticas e transeuntes. Outra coisa que chama muita atenção é a grande população indígena, mais especificamente karajá, que transita pela cidade em aparente harmonia com a "população urbana". Isso, para mim, contrasta de imediato com o pouco que conheci de Primavera do Leste e outras cidades próximas à terras indígenas (Barra do Garças, General Carneiro), nas quais a população xavante ou bororo parece estar mais segregadas da "população urbana" (acentuando a divisão entre, de uma lado, descendentes da colonização gaúcha e migrantes e de outro indígenas). Não é incomum, ao caminhar por São Félix, que escutemos nas rodas de conversa tanto o idioma português quanto o idioma Iny (karajá). Pela noite, partimos de barco de alumínio a motor rumo à aldeia Santa Isabel (a mais próxima à São Félix), onde mora Juanahú e sua família e onde pela primeira vez, por mais estranho que pareça, conheci uma aldeia indígena sem luz elétrica. Juanahú disponibilizou seu antigo hetô (casa), para que pudéssemos dormir pelos dois primeiros dias, já que a o ritual acontecerá na aldeia Fontoura para onde seguiremos no domingo. Pela noite, além de um incômodo causado pelo frio advindo do vento da beira do rio do que qual eu mal me protegia através de minha rede vazada, a cabeça fervilhante de ideias e a ansiedade a pleno vapor dificultaram o sono.

Acordei às 7:00 no hetô, na aldeia Santa Isabel e, apesar da noite mal dormida e do incômodo frio, a expectativa para o dia aliviou o cansaço. Tomamos um café com bolachas generosamente ofertado pela esposa de Juanahú e partimos rumo à cidade de São Félix.

Foto 22. Juanahú Karajá, Divino Tserewahú e Caio Lazaneo a caminho da Aldeia Santa Isabel. (foto: Paulinho Kadojeba)

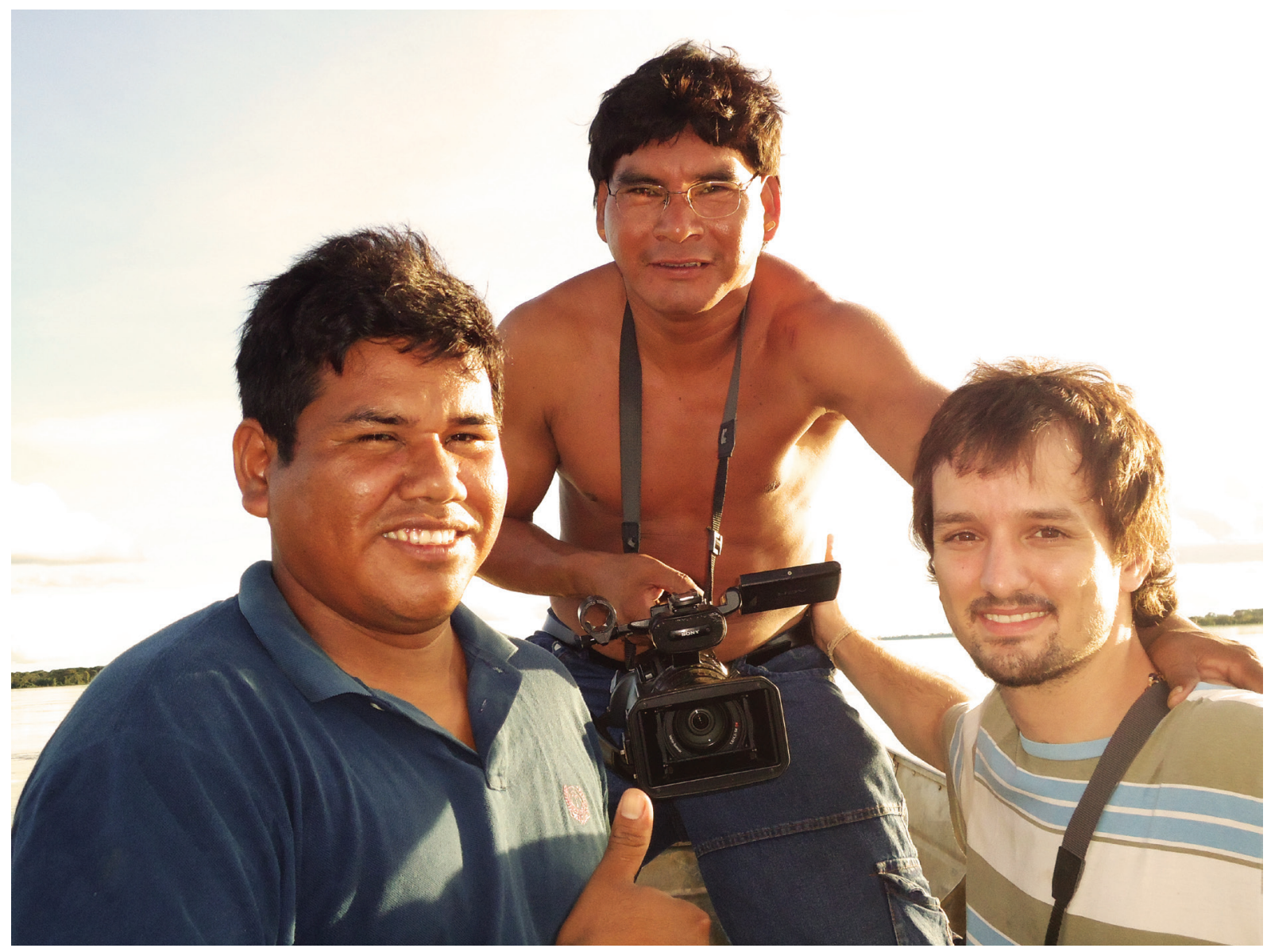




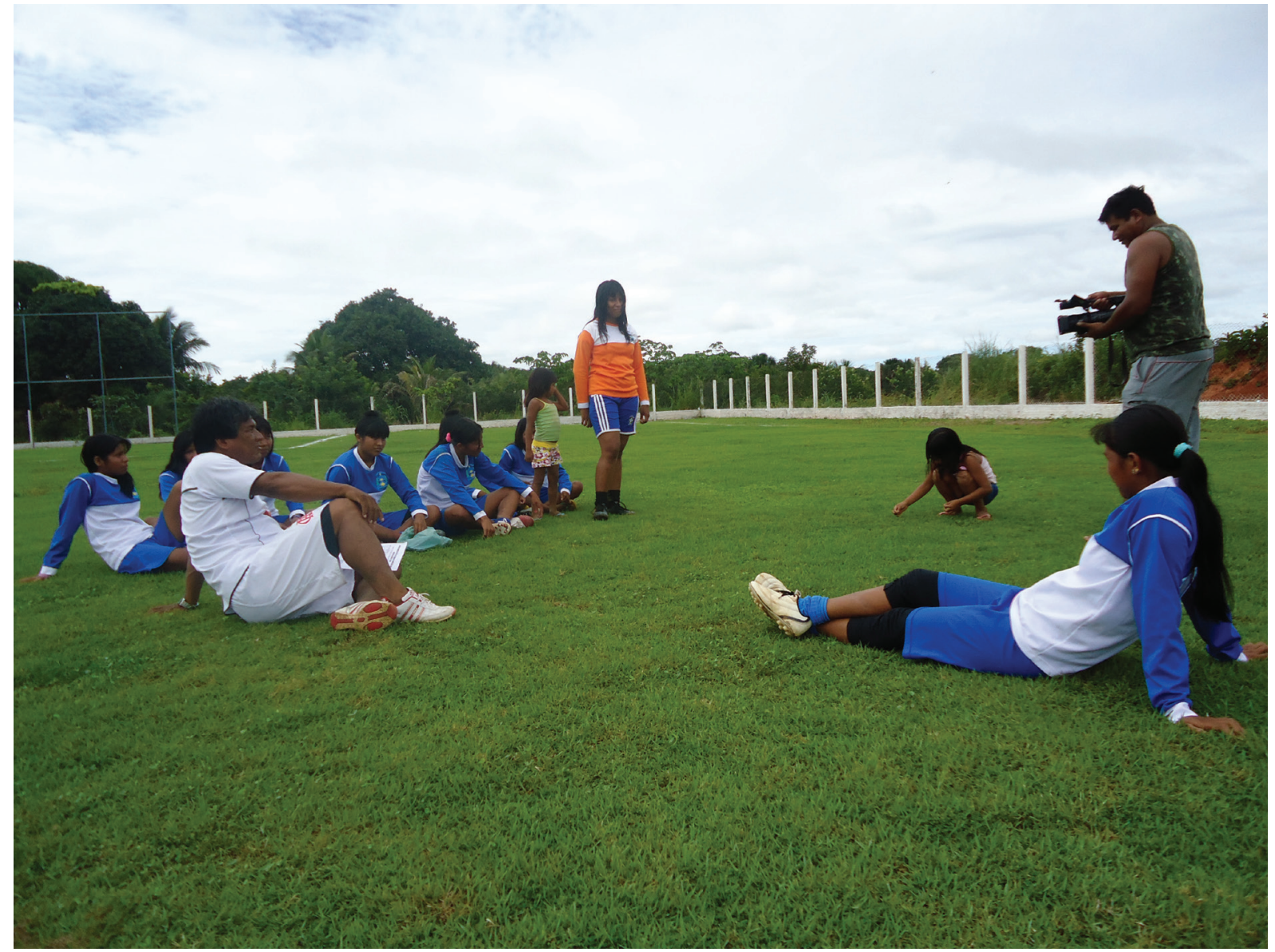

Foto 23. Juanahú Karajá filma o time de futebol feminino da Aldeia Santa Isabel. (foto: Caio Lazaneo)

Durante o dia interagimos com alguns moradores de São Félix, amigos de Juanahú, como Samuel, um karajá que atuou no filme "Brincando nos campos do senhor", de Hector Babenco. Samuel administra um centro de cultura karajá. Aproveitamos o dia para assistir jogos femininos de equipes de futebol de aldeias karajás que se enfrentam em um campo municipal. Empolgado pelos equipamentos que trouxemos conosco, Juanahú começou imediatamente a registrar lances das partidas e entrevistar as jogadoras e o técnico do time. Os jogos são organizados pela prefeitura municipal que administra uma espécie de liga, ofertando premiações aos times vencedores dos campeonatos, o que já é suficiente para que as partidas sejam levadas com seriedade e atraíam atenção de torcedores, como a esposa de Juanahú que fez questão de ir da aldeia à cidade para torcer pelo time da aldeia Santa Isabel. A apropriação do futebol, enquanto fenômeno esportivo, lúdico e cultural, pelas comunidades indígenas que conheci é algo que sempre me chama atenção. Tanto os xavantes quanto os karajás (com maior frequência entre os homens, não sendo raro entre as mulheres) são, além de praticantes cotidianos do futebol, profundos entendedores e espectadores (televisivos) de campeonatos regionais e nacionais. Depois das partidas, conversamos por um tempo no restaurante de Messias que fica às margens do rio Araguaia. Ao entardecer retornamos à aldeia Santa Isabel, jantamos no hetô de Juanahú e descansamos para o dia seguinte, no qual viajaremos para a aldeia Fontoura, onde acontecerá o ritual Hetohokã.

A viagem de "voadeira" (barco de alumínio com motor de 15 "cavalos" ou, na brincadeira de Juanahú, 15 "botos") rio abaixo, de Santa Isabel à Fontoura, levou 1 hora e 20 minutos. Chegamos à Fontoura por volta das onze horas da manhã e nos instalamos na 
casa da equipe de saúde da aldeia, onde há alguns quartos, um banheiro e uma cozinha, de aspecto ligeiramente abandonado, que é esporadicamente utilizada por agentes de saúde e, eventualmente, missionários. As primeiras impressões que tive da aldeia e do povo Iny (Karajá) são de uma simpatia latente, muito acolhimento e curiosidade. Juanahú nos levou para conhecer a aldeia, que tem uma população aproximada de 700 pessoas. Os hetôs (casas), geralmente, são retangulares e, em sua maioria, de palha. Há algumas poucas construções de alvenaria e o abastecimento de energia é feito por gerador que funciona até às 20h. A disposição das casas não obedece uma organização tão circunscrita como das aldeias xavantes e bororos que conheci. Tive a impressão de que a aldeia se assemelha a um "vilarejo" com vias paralelas e que, num dos limites, leva à casa dos homens onde são guardados os "aruanãs" (onde a presença de mulheres e crianças não iniciadas é proibida). Juanahú fez um acordo com duas jovens karajás que irão preparar nossas refeições. No almoço do primeiro dia, arroz, feijão e mandioca. Para o jantar, comprei de um indígena três peixes assados bastante saborosos, e misturamos aos ingredientes do almoço.

Por volta da meia noite, começamos a realizar os primeiros registros fílmicos de partes do ritual, seguindo a orientação de Juanahú. Aruanãs, em duplas, no local próximo de onde nos próximos dias será erguida a Hetohokã (Casa Grande) e moças karajás, quase desnudas, também em duplas, dançavam em linha reta num movimento em que os Aruanãs, com seus maracás e cantos, se dirigiam para frente e as moças os olhavam de frente, caminhando de costas, e fazendo com as mãos um movimento circular na região do ventre. A despeito do contato com os toris (brancos) e do hábito de, normalmente, trajarem vestimentas dos habitantes da cidade, a nossa presença com câmeras e, mesmo a minha (um tori estranho àquele contexto), não pareceu

Foto 24. Aruanãs na noite da Aldeia Fontoura. (foto: Caio Lazaneo)

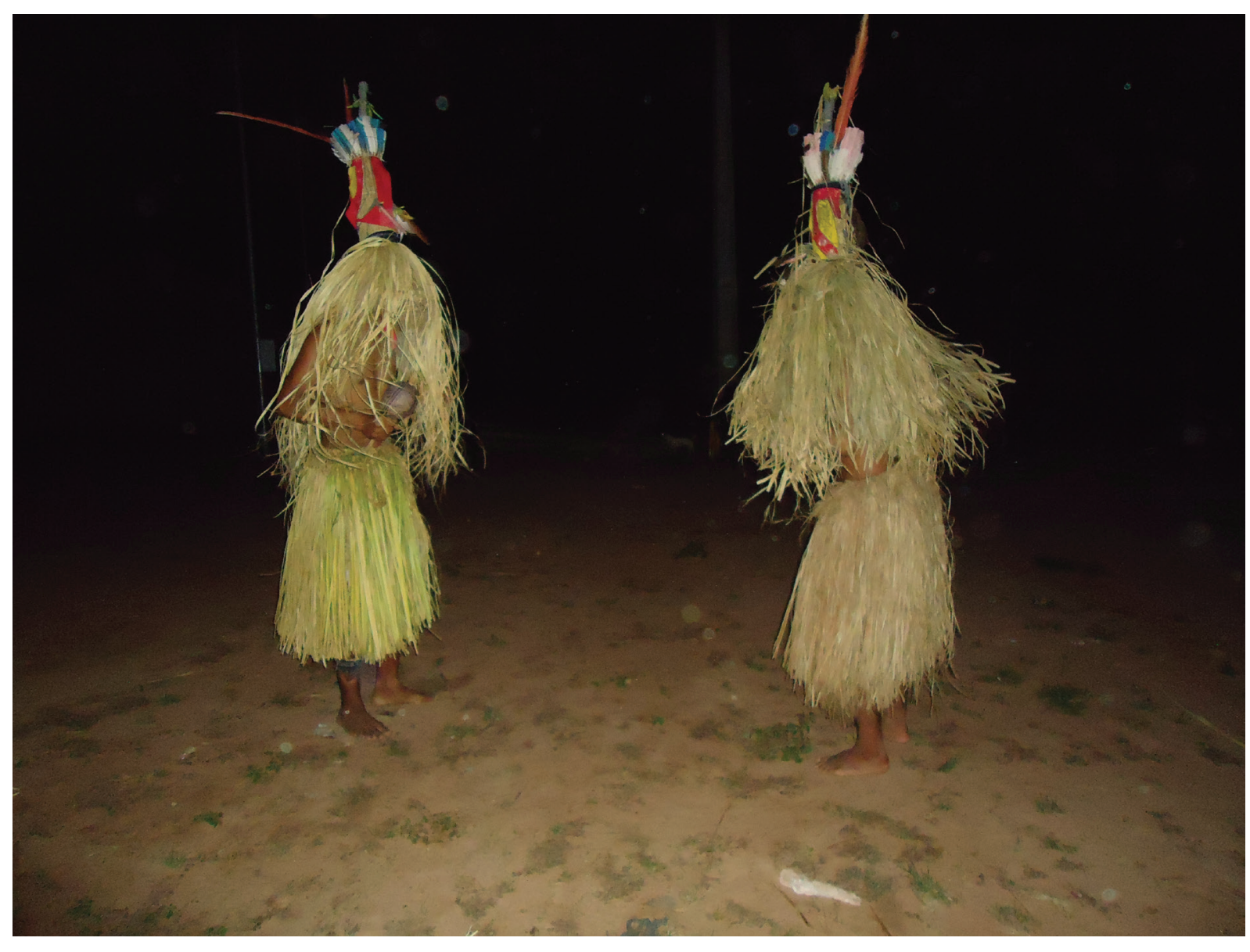




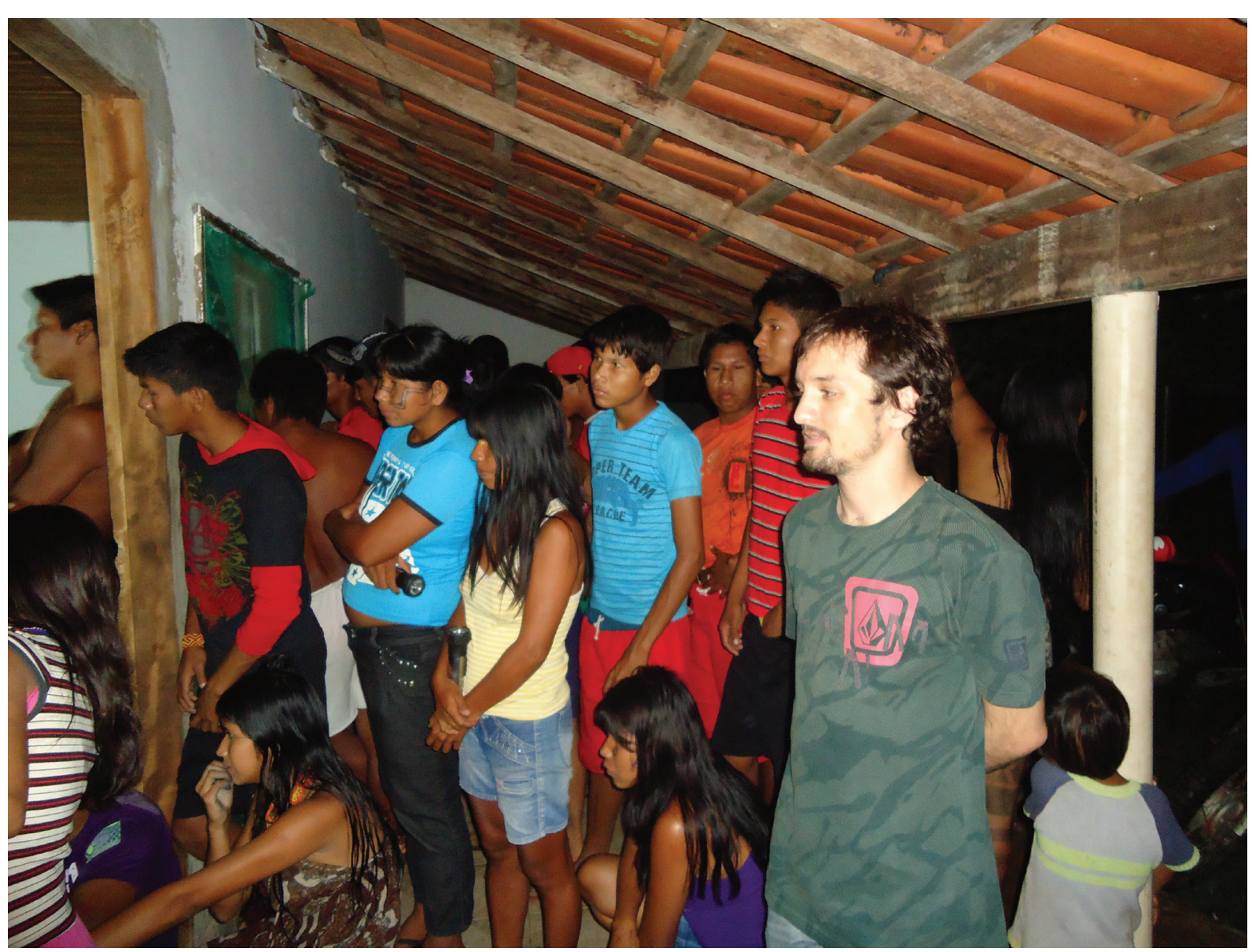

Foto 25. Lado externo da casa de saúde da aldeia. A população karajá assiste à projeção das filmagens do dia. (foto: Divino Tserewahú)

causar nenhum desconforto mas, pelo contrário, os aruanãs e moças contribuíam bastante com uma quase misé-en-scene. Acredito que dificilmente teríamos conseguido tamanha naturalidade se Juanahú não fosse nosso interlocutor, além de principal realizador do filme, e ficou evidente o respeito que a comunidade nutre por ele, além do entusiasmo em participar de uma produção audiovisual realizada a partir de um karajá.

O nosso segundo dia na aldeia foi de intenso trabalho no registro de entrevistas e cenas do universo do ritual Hetohokã. Além de oferecermos treinamento de câmera e linguagem cinematográfica à Juanahu, também ensinamos Mairu, um amigo de Juanahu, a manusear o equipamento e também pensar no processo de realização fílmico. Da minha parte registrei, fundamentalmente, aspectos em que a possibilidade "reflexiva" se mostrou propícia, qual seja, cenas em que os indígenas filmavam e, por trás da câmera, dialogavam sobre o registro. O que era antes um clássico "objeto" antropológico transformando-se em sujeito da pesquisa.

A intensa chuva que caiu praticamente por todo o dia prejudicou danças e cantos programados, entretanto, conseguimos bastante material para o futuro documentário. Pelo fim da tarde realizei uma entrevista com Koxini, um senhor Karajá com ampla atuação no movimento indígena e que possui formação em história e administração. Koxini viajou muitas partes do mundo conferindo palestras sobre a cultura indígena (e mais particularmente a karajá) e, como me disse reiteradas vezes, apesar de conhecer o mundo, reconhece e reafirma a importância do seu lugar: Sua aldeia Fontoura. Uma postura que, de imediato, remete ao célebre aforismo de Tolstói, "Se queres ser universal, começa por pintar a tua aldeia". Na entrevista privilegiei perguntas sobre a relação universidade-comunidade, pois sabia de antemão que Koxini teria um ponto de vista muito interessante sobre essa questão. Pela noite projetamos numa parede da cozinha da casa que estamos alojados, os filmes curta-metragens da oficina de cinema de Sangradouro além de fotos que batemos durante os dois dia de gravações. A cozinha e a parte de 


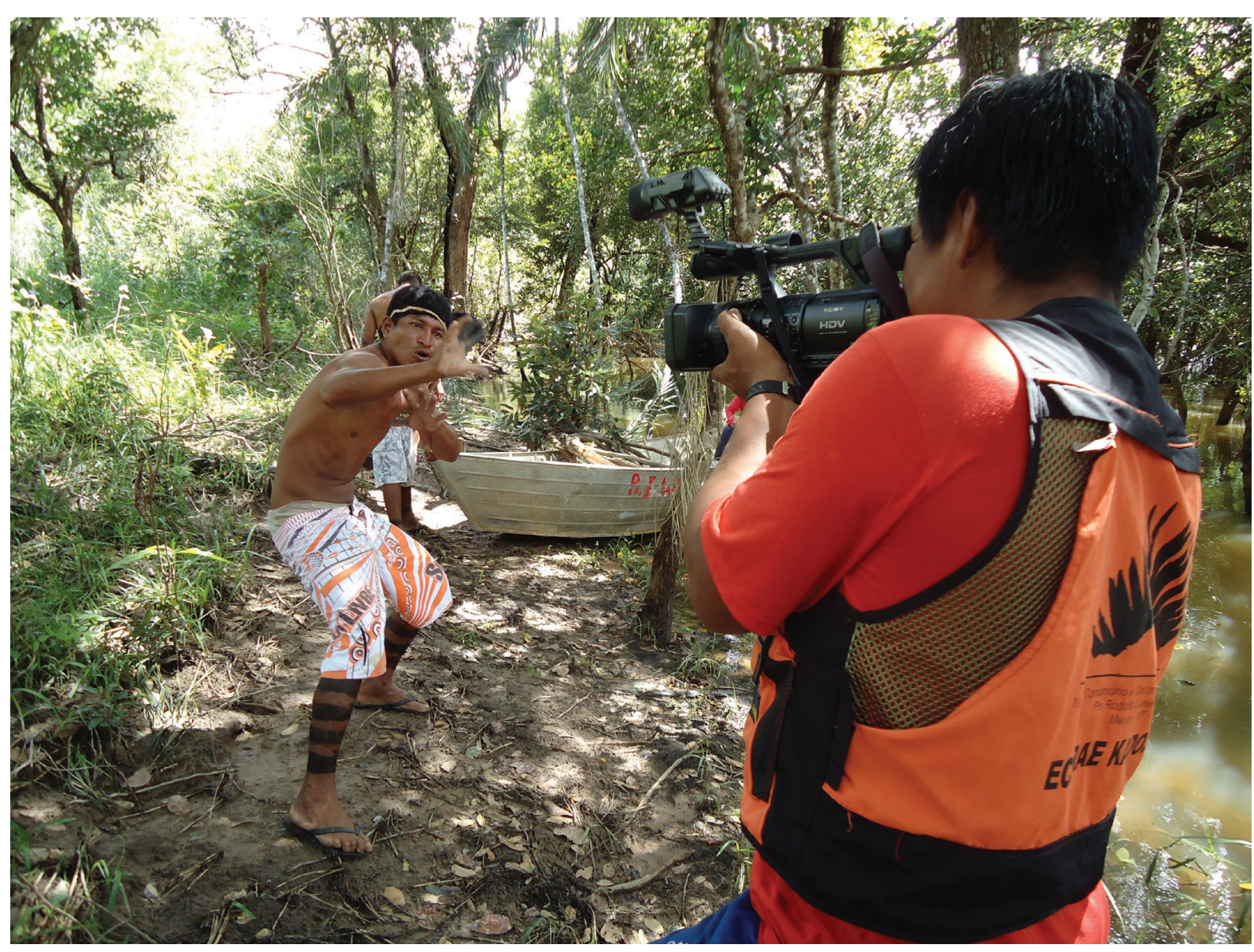

Foto 26. Paulinho Kadojeba filma Kumairú Karajá mimetizando um macaco. (foto: Caio Lazaneo)

fora da casa ficaram tomadas por crianças, jovens e adultos da comunidade, a meu ver, ansiosos por um franco diálogo audiovisual. Nesses trabalhos de campo com comunidades é sempre surpreendente a receptividade e a possibilidade de retorno que podemos encontrar através do diálogo audiovisual e as respectivas comunidades. Depois da sessão de cinema indígena e fotografia nos reunimos (Divino, Juanahu, Paulinho e eu) para planejarmos as gravações do dia seguinte.

Logo pela manhã, por volta das 8:30, saímos eu, Mairú, Paulinho e três karajás (Kumairu, Teixibu e Txika), de voadeira para buscarmos o cipó (Hatyriry) que será utilizado no ritual Hetohokã. Como o processo do corte do cipó é uma etapa relevante para o ritual, dividimos a equipe no dia anterior para que déssemos conta de gravar essa etapa enquanto outra parte da equipe (Juanahú e Divino) ficaria na aldeia para colher algumas entrevistas. O cipó é utilizado para unir as toras de sustentação da estrutura da casa grande e também para locomover o Toó (um tronco imenso de árvore enterrado próximo a casa dos homens e que durante o Hetohokã os homens da aldeia sede devem defendê-lo afim de não permitir que os homens de uma das aldeias visitantes consigam derrubá-lo). Como se trata de um cipó específico, que em boa parte possui um largo diâmetro feito galhos de árvores, nem sempre pode ser encontrado muito próximo à aldeia. Deste modo, navegamos pelo Araguaia enquanto os karajás, profundos conhecedores do local, percorriam a vista em busca do cipó. Encontramos em dois locais distantes um do outro. Durante o corte, Kumairu incorporava ora um macaco, ora uma raposa, com uma mimese muito peculiar na qual misturava gestos do animal com palavras enroladas na língua karajá, em meio a gritos estridentes. Segundo me contara Mairú, a raposa se incomodava com o fato de que o macaco levaria seu cipó embora. Achei divertido seu jogo e até mesmo convidativo. Quando um grosso galho caiu em sua cabeça, no segundo local em que os karajás cortavam o cipó, Kumairu passou novamente a mimetizar um macaco, passando a mão na cabeça e se mostrando 


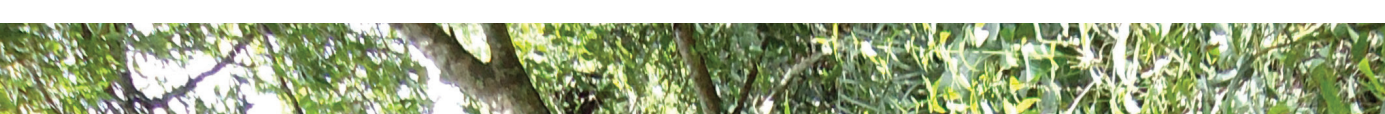

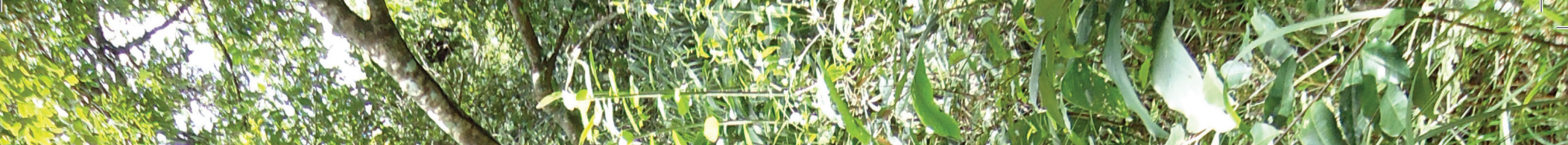

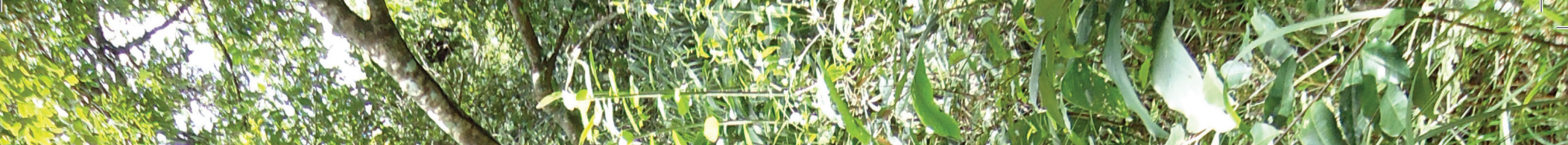
21
2

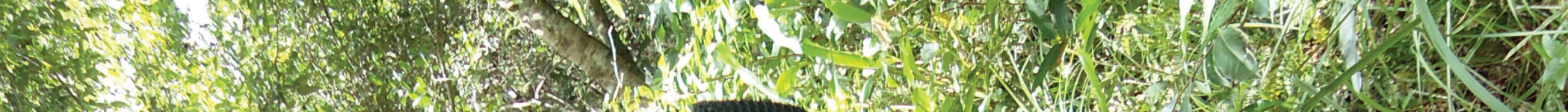
2
$*$

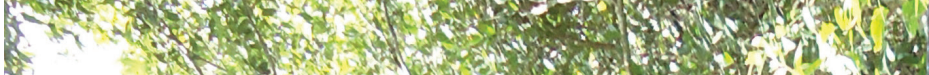
8

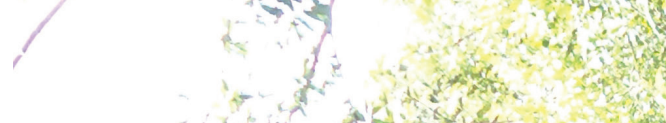

5

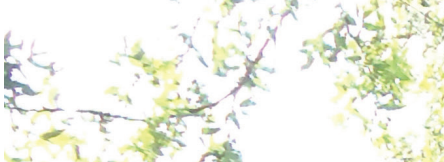

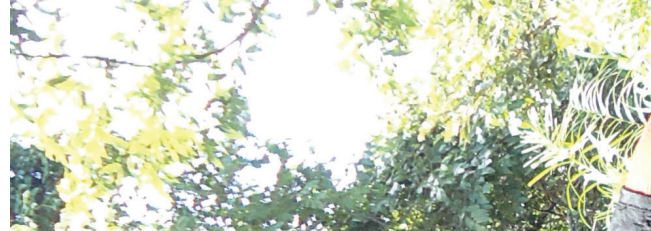
$4 x^{2} x^{2}$ Q7.

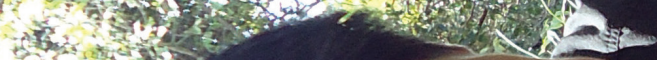

and

gren
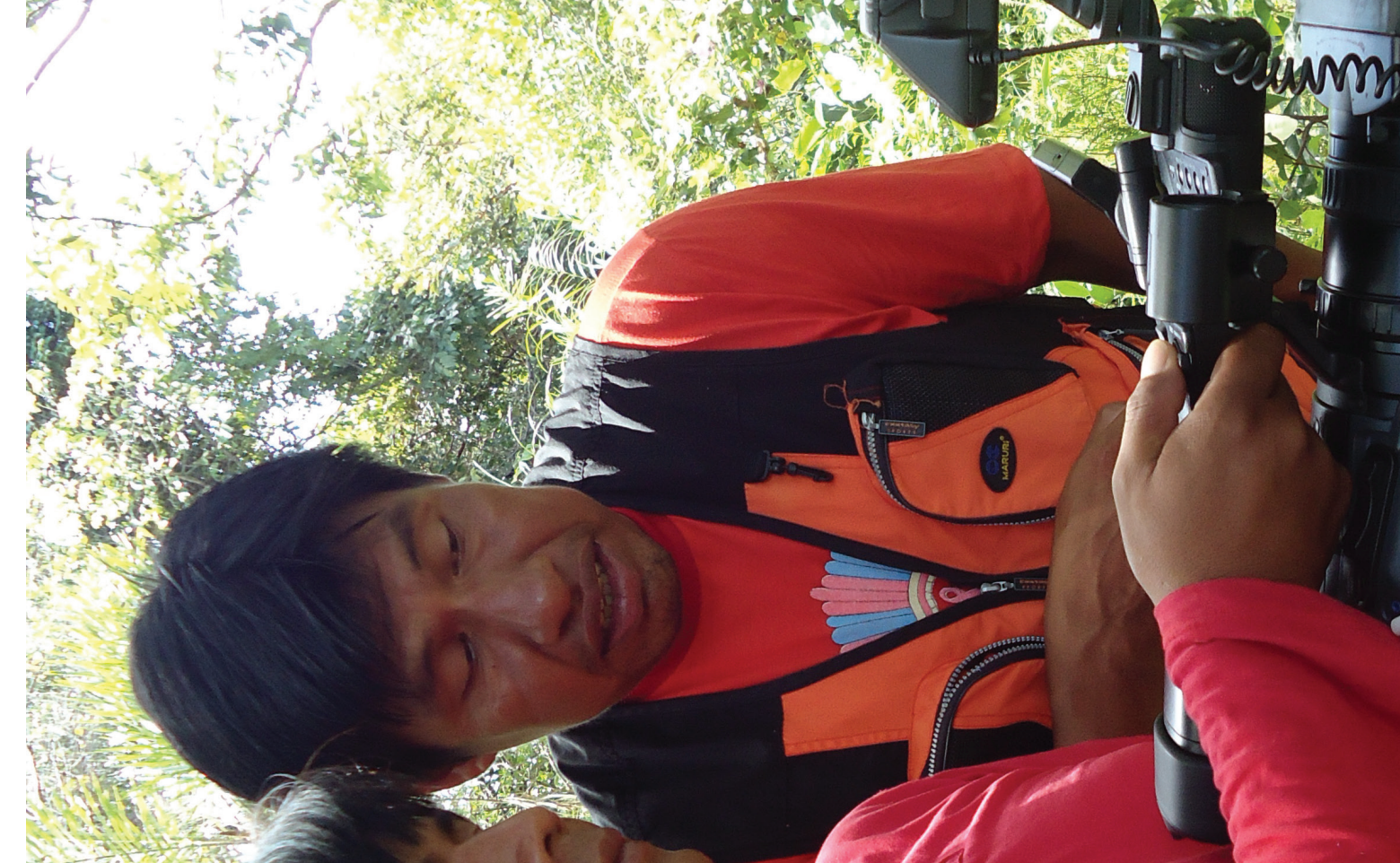
Ir then
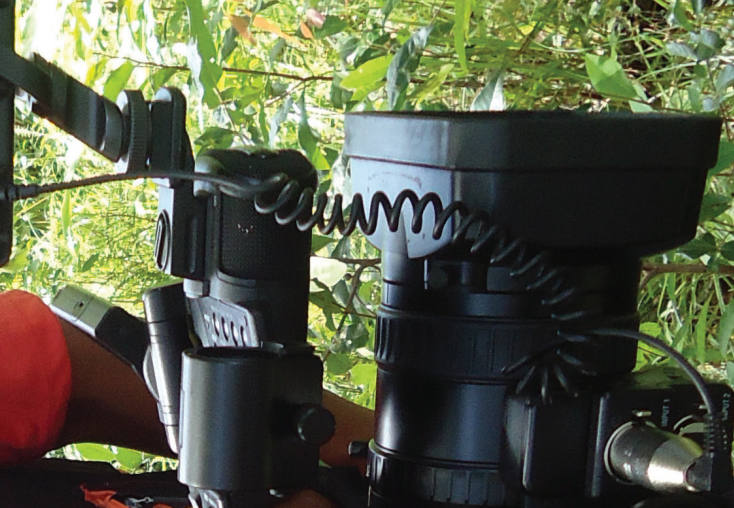
irritado com o acidente. Mairú depois me explicou que o "espírito" do macaco e da "raposa" se fazem presentes em algumas situações específicas como aquela que participávamos (o da busca pelo cipó Hatyriry). Quando durante a navegação avistamos uma árvore que me chamou a atenção e perguntei à Kumairu qual era seu nome, ele me explicou que naquela espécie de árvore os camaleões gostavam de ficar e que para os karajás também existia o "espírito do camaleão". De qualquer forma, diante dessa complexa cosmovisão, levo o importante princípio de que a experiência também deve ser compreendida durante sua vivência e que, como tori (não indígena) habituado a uma (ana)lógica ocidental, uma ecologia indígena é sempre complexa e fascinante, sobretudo, nessa rica, plural e rara experiência da produção partilhada. Retornamos à aldeia próximo ao horário do biró (comida) e encontramos Divino e Juanahú que gravavam uma entrevista com o cacique da aldeia. A alimentação de todos os dias têm sido à base de muito peixe, arroz, feijão e mandioca. Pela tarde gravamos (toda a equipe) cenas e entrevista com pescadores karajás que, especificamente nessa fase, realizam a atividade para suprir a demanda de alimentos durante o ritual. No caminho de volta da pescaria, o sol se punha com um beleza indescritível, exibindo seus reflexos por todo o Araguaia que, como um espelho estonteante, não nos permitia precisar os limites entre céu e rio. Inebriados, apenas tentávamos através das filmadores e câmeras fotográficas contemplar a experiência. Divino se deslocou para a frente do barco, e em pé procurava um enquadramento no qual pudesse melhor filmar aquele encontro. Assim se descortinou, por sua vez, uma das cenas, para mim, mais sublimes deste percurso e que felizmente pude fotografar. Recordei quando em Sangradouro, os xavantes me diziam sobre Tomõre, nome com o qual apelidavam Divino e que significa "olho da câmera". Como um presente, a minha frente, Divino empunhava sua câmera, tal qual um híbrido cine-olho tomõre,

Foto 28. Paulinho Kadojeba ensina Mairú Karajá. (foto: Caio Lazaneo)

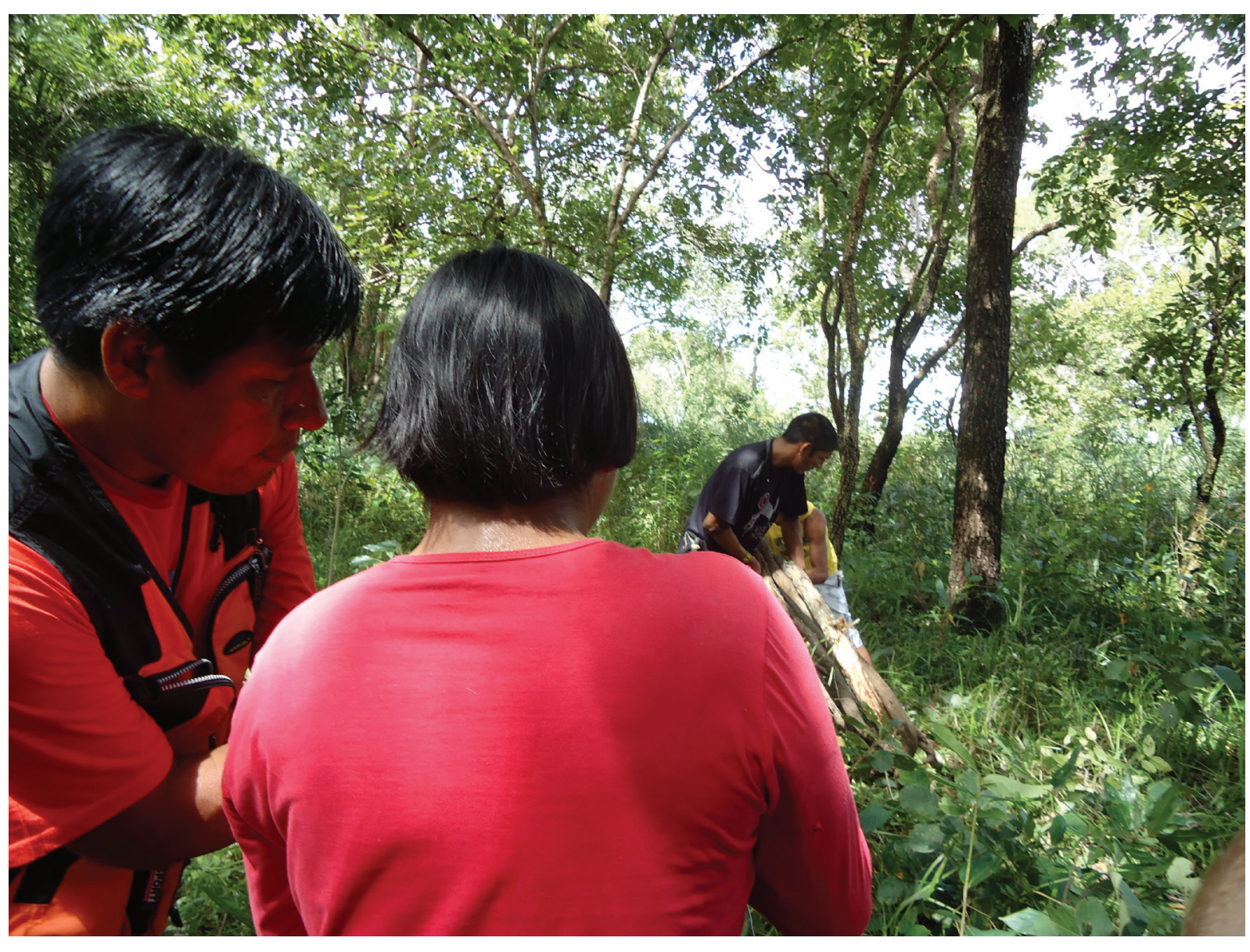




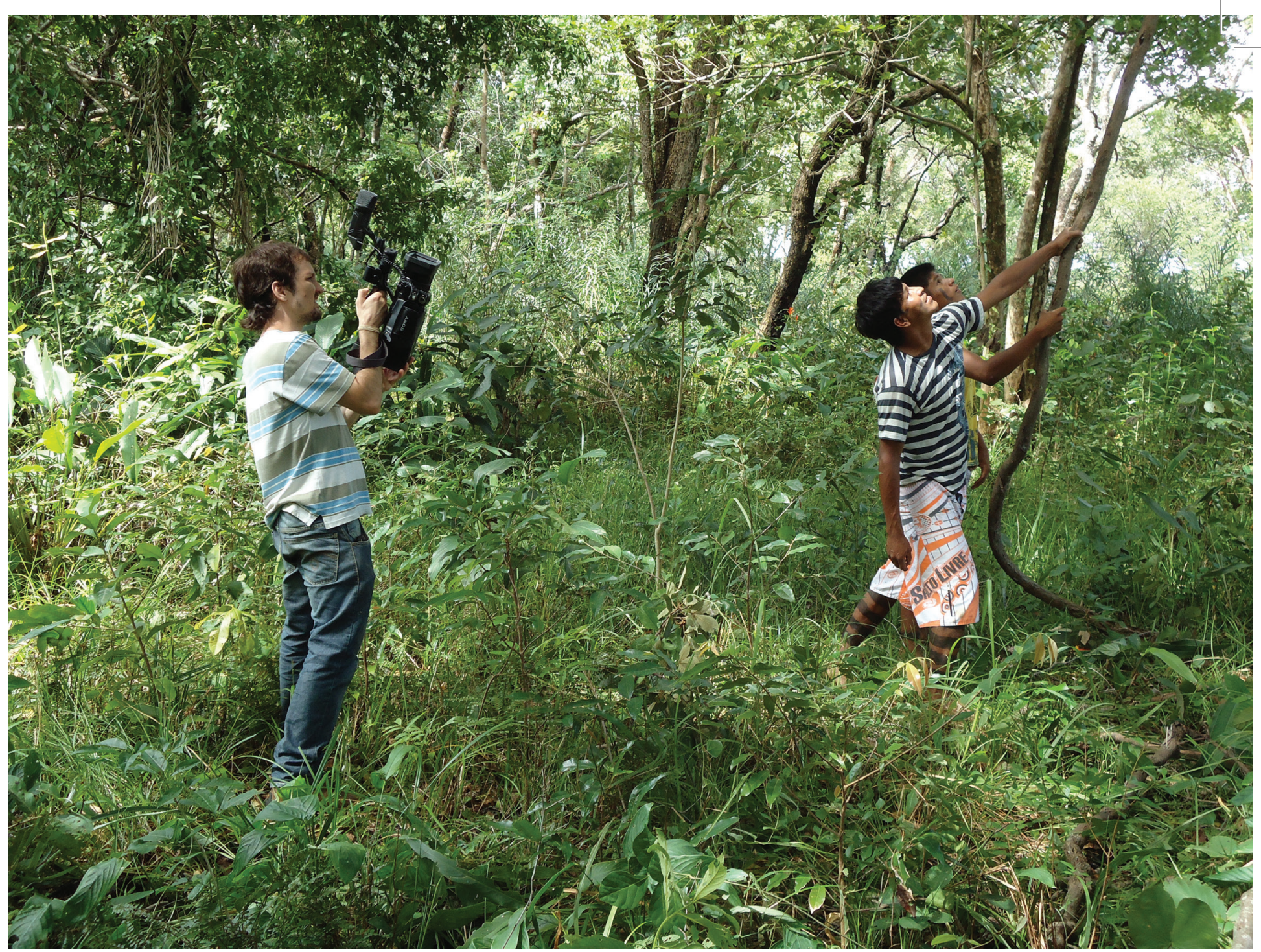

Foto 29. Caio Lazaneo filma cipó Hatyriry sendo retirado do alto das árvores. (foto: Paulinho Kadojeba)

e a moldura do belo diálogo do Araguaia com o sol que, através de sua luz, transformava e sugeria toda a extensão da água como um imenso espelho de reflexividade: Xavante-AraguaiaCine-olho-Reflexividade.

Para coroar um dia tão rico de informações e pleno de experiências insólitas, realizamos um diálogo de toda a equipe e Koxini na volta à aldeia.

A noite ainda nos reservou energia suficiente para o exercício do retorno, no qual, depois do jantar, exibimos no projetor, na já tradicional parede da cozinha, as cenas gravadas durante o dia com a comunidade e para a comunidade. 
Infelizmente Divino e eu nos despediremos amanhã e, desse modo, não acompanharemos os próximos quatro dias na aldeia Fontoura. Da nossa equipe permanecerão por aqui apenas Paulinho, Juanahú e Mairú. Quando recebi o contato de Divino para participar do evento, imaginávamos que a data final do Hetohokã (como anteriormente explicado por Juanahú) seria no dia 10, porém quando chegamos à São Félix, descobrimos que o ritual havia sido adiado e assim somente terminará no dia 13. Como na equipe eu e Divino já possuíamos compromissos prévios, precisamos manter a data marcada para a volta. Das experiências vivenciadas hoje, destaco a pintura a base de jenipapo feita por índias karajás que eu e Divino recebemos na face e no corpo, segundo Juanahú como sinal de agradecimento. O povo Iny possui um artesanato bastante diferenciado e um traço muito peculiar que acompanha suas pinturas. Foi uma grande honra receber a pintura, uma demonstração de acolhimento e reciprocidade. Aos poucos, com a proximidade da partida, começo a recapitular os bons momentos tão intensos da última semana. Levarei comigo a lembrança de pessoas imprescindíveis, como Koxini, e mesmo o meu amigo e anfitrião Juanahú e seu "escudeiro" Mairú, ambos acometidos pela intensa "fome" de audiovisual para o registro de sua cultura. $\mathrm{O}$ fim do dia foi mais uma vez dedicado a prática reflexiva, o retorno das imagens e sons por nós capturados. Desta vez, a projeção ocorreu num prédio maior que, a despeito do aspecto de abandono, funciona como um pátio para comportar reuniões maiores. O exercício diário de projetar nosso trabalho para a comunidade parece ter despertado o interesse de todos e feito muito sucesso. O pátio do prédio ficou completamente lotado e, seguramente, posso afirmar que quase toda a população da aldeia se apertava para assistir nossos registros e expressar à sua maneira, com sorrisos, gargalhadas, tédio ou mesmo provocações (geralmente feitas dos homens às mulheres registradas) a cada sequência de planos e tomadas. Uma situação essa muito peculiar, na qual muitas pessoas se dispõem a assistir um material bruto, não lapidado, mas de evidente importância e significação para uma comunidade tão rica sonora e imageticamente. Para minha pesquisa e experiência pessoal, esse exercício é sempre gratificante. Ao voltarmos para a casa, o fim da noite foi dedicado à diálogos, principalmente entre Paulinho, Divino e eu, sobre nossa dinâmica como equipe e sobre ideias futuras. Com mais um aperto no peito, tentarei dormir me preparando para, ao levantar, deixar Btõiry (Aldeia Fontoura) por um período que não poderei prever mas, ainda assim, com a certeza que parto daqui um pouco mais Iny. 

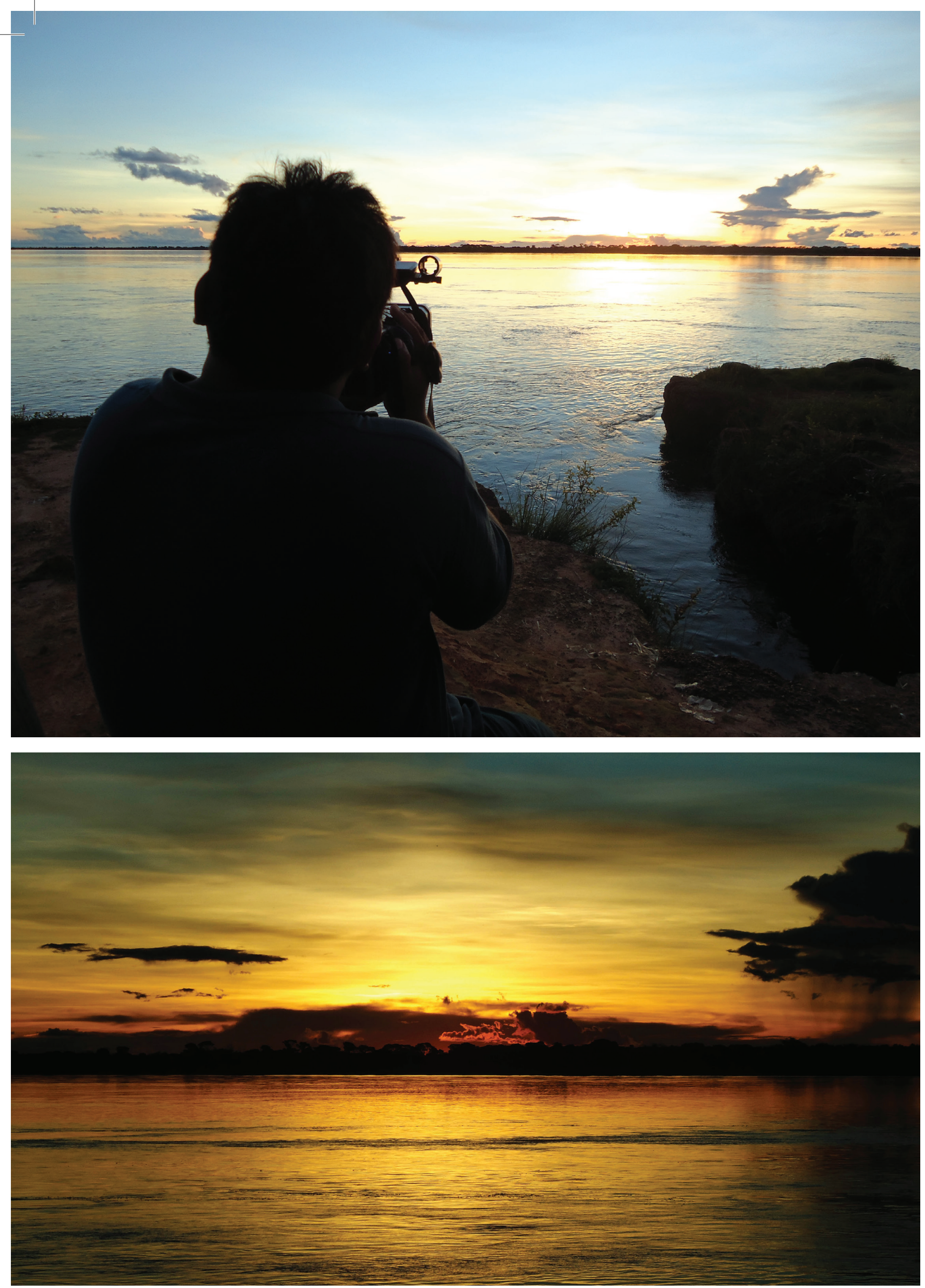

Foto 35. Juanahú filma o pôr-do-sol no rio Araguaia. (foto: Caio Lazaneo)

Foto 36. Arrebol no rio Araguaia (foto: Caio Lazaneo) 


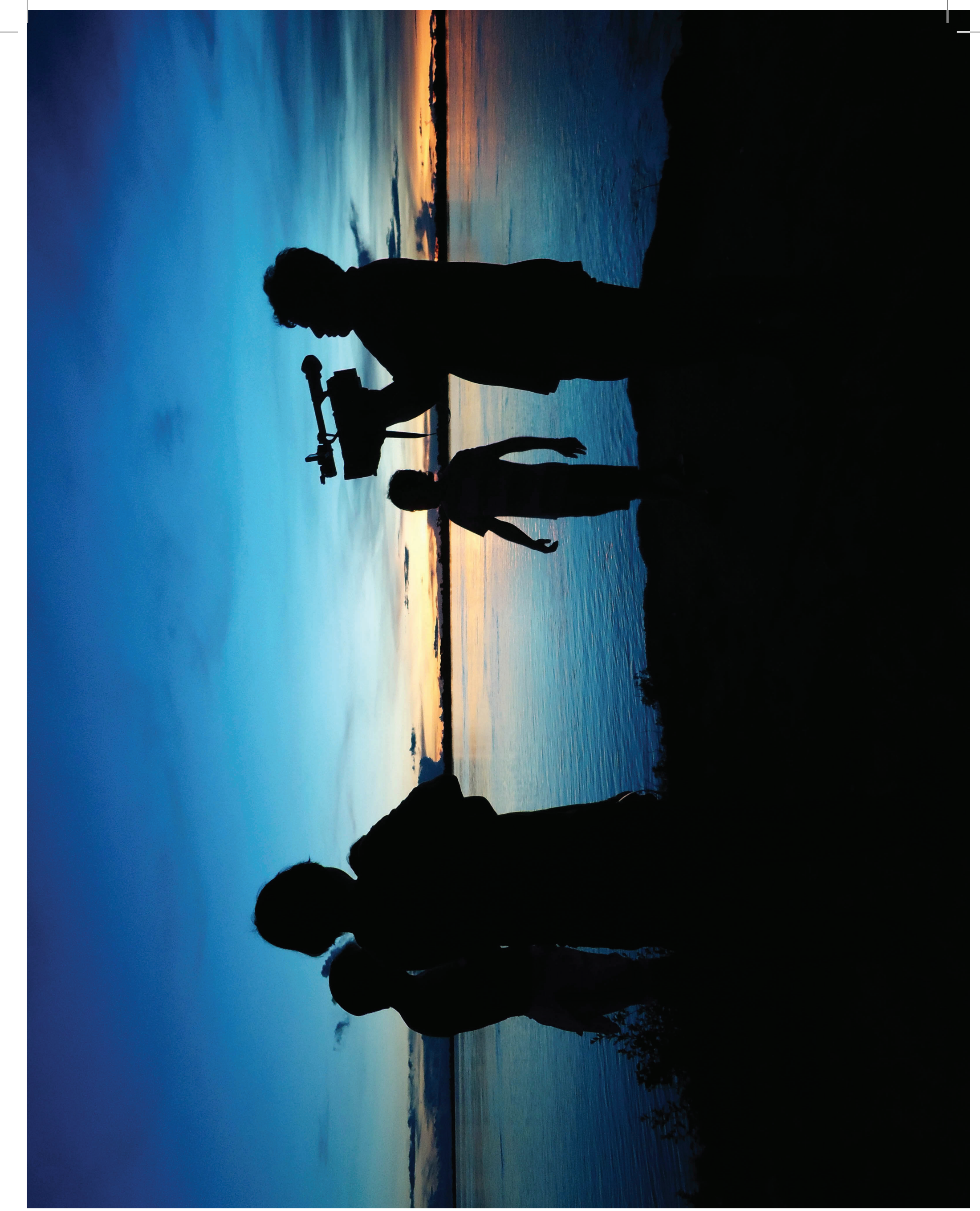

Foto 37. Silhuetas araguaias: Diálogo da equipe com Koxini às margens do rio Araguaia. 


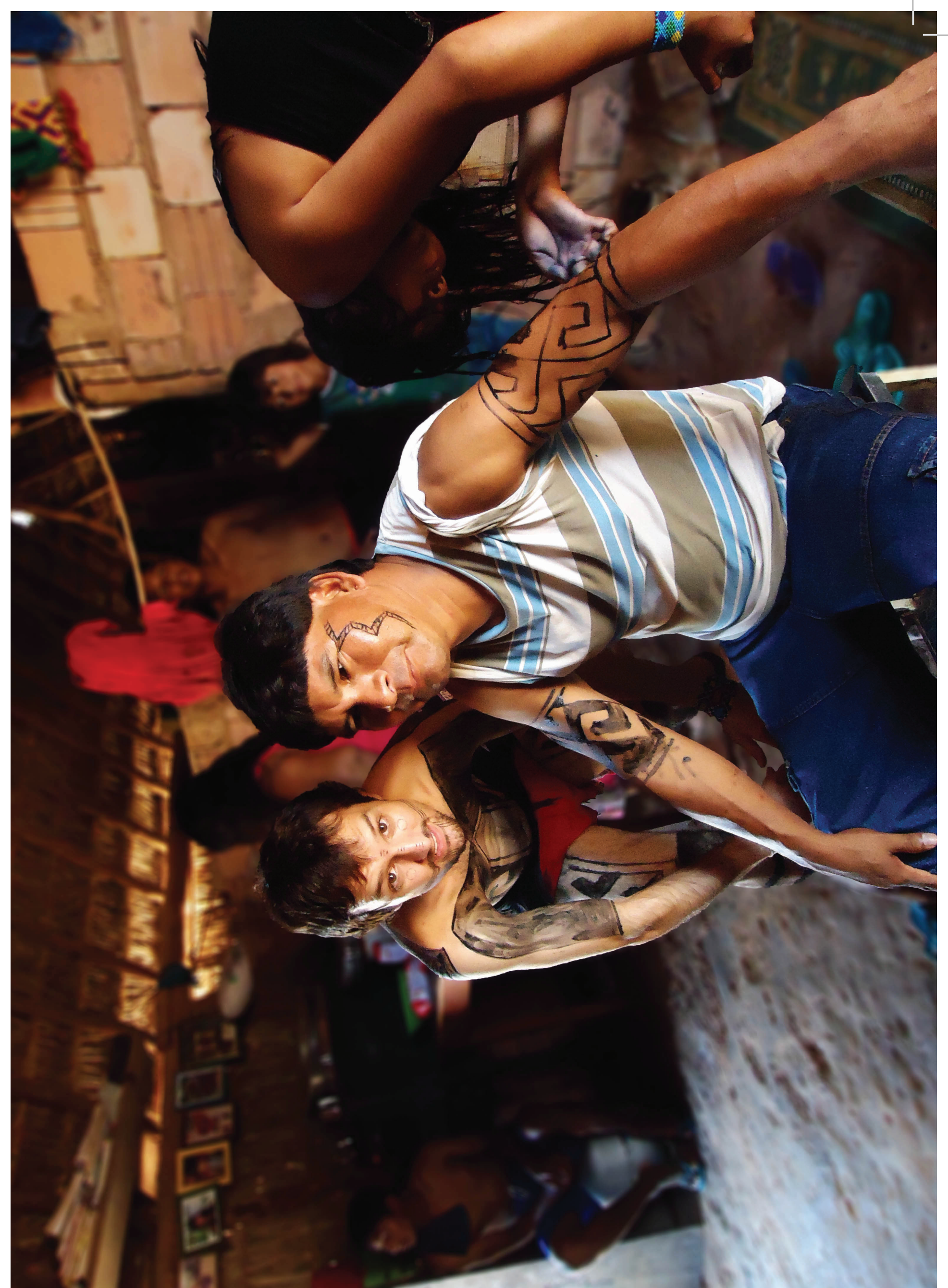

Foto 40. Caio Lazaneo e Divino Tserewahú recebem a pintura karajá. (foto: Paulinho Kadojeba) 


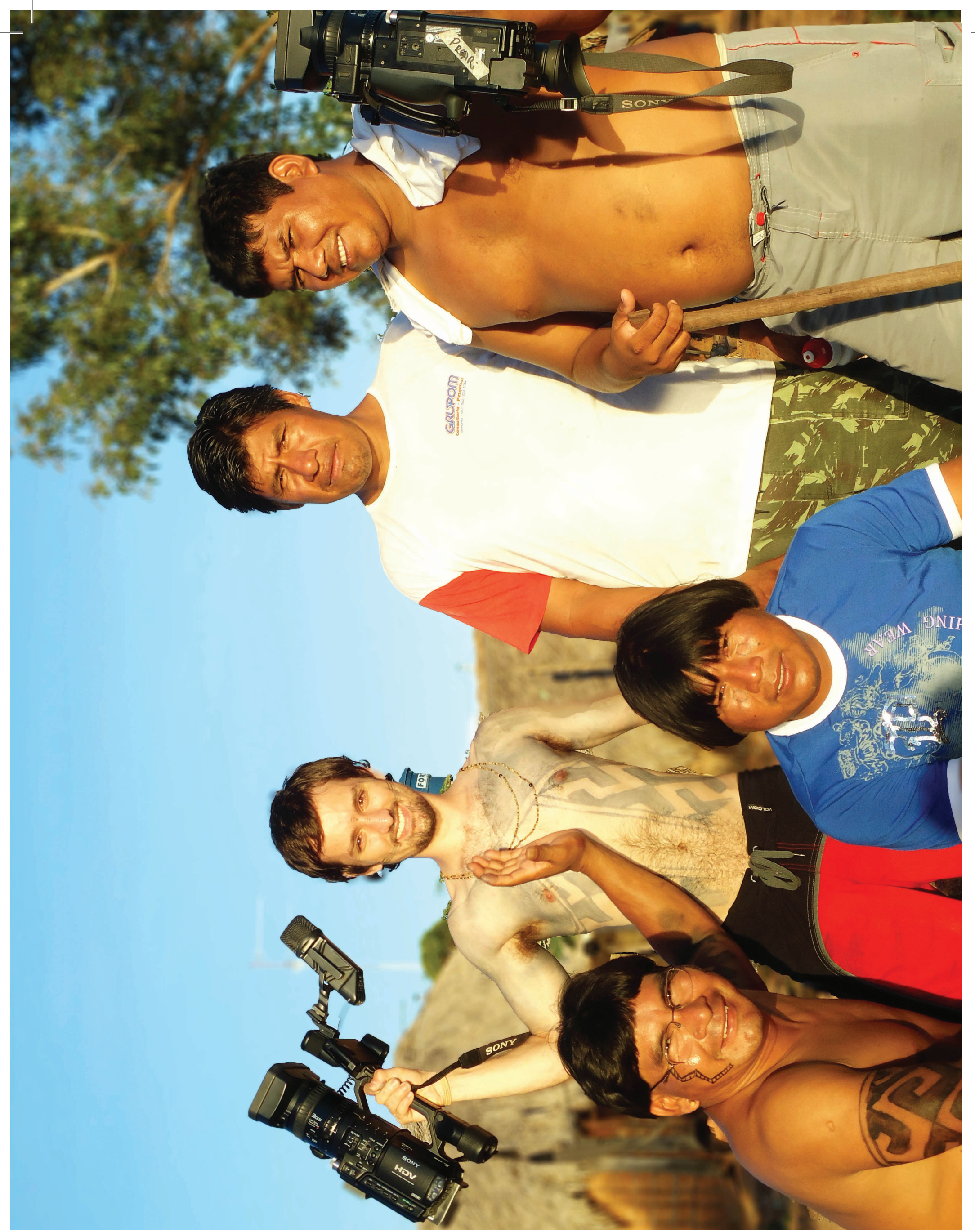




\subsection{Partilha III - Ritual Wapté Mñoño Xavante}

A terceira atividade da equipe do CEDIPP, desta vez através da minha presença e de Divino Tserewahú, se dera no retorno à aldeia Sangradouro (de 02 à 28 de agosto de 2011) para o registro da etapa final do ritual Wapté Mñoño, iniciação do jovem xavante. A proposta da produção partilhada consistiu em auxiliar Divino Tserewahú e os outros xavantes que, por ventura, também participassem da equipe. Assim como viabilizarmos a possibilidade da montagem do filme na ECA- USP.

Um novo itinerário de viagem, desta vez para Cuiabá partindo de Guarulhos. Novas perspectivas num já conhecido caminho, ansioso por reencontrar os amigos xavantes de Sangradouro, em plena atividade no dias que finalizarão o "Wapté Mnhõnõ”, ritual de iniciação do jovem xavante. Desta vez, segue em minha companhia o grande amigo Di Pannacci, que acaba de retornar de Madrid onde cursou sua especialização em direção de fotografia para cinema. Partimos de Guarulhos no vôo das 10:10 da manhã e chegamos em Cuiabá às 11:30 (horário local). De Cuiabá à Primavera, mais quatro horas de viagem, onde Divino ansiosamente nos aguardava junto de seu filho mais velho (que quando chegamos cortava o cabelo em um cabelereiro na rodoviária) e de Graciano, vice-cacique de Sangradouro. Di guiou o carro de Graciano nos 45 quilômetros que separam Primavera de Sangradouro. No caminho, além do papo descontraído e das brincadeiras, Divino e Graciano explicaram rapidamente o panorama da situação da aldeia que continua dividida politicamente, o que, consequentemente, também divide o ritual. Expliquei brevemente para Divino minha perspectiva da viagem que consiste em, além de auxiliá-los nos registro da festa, pesquisar a relação dele, como interlocutor, e de seus registros, como produtos desse processo, com a comunidade xavante. Ele rapidamente compreendeu a proposta e afirmou que irá me auxiliar nessa realização partilhada, como nas outras situações de registros e pesquisas nas outras viagens que juntos fizemos. Chegamos em Sangradouro pela noite e nos acomodamos no alojamento da missão, onde na manhã seguinte começaremos a trabalhar.

Por volta das seis e meia da manhã, Divino e João Cassiano (seu meio-irmão) passaram para nos buscar de caminhonete, que ainda carregava na carroceria uma camada de sangue fresco das toins (antas) caçadas na madrugada (que segundo o Divino eram quatro) e que lá haviam sido transportadas. Quando chegamos à aldeia, não muito distante da missão, Divino, em seu papel de anfitrião, junto de César (realizador audiovisual xavante) nos guiou por diversas casas onde, nos quintais, diferentes grupos assavam em brasa as partes dos animais sobre os girais, tocos roliços de madeira enfileirados. Embora tenha um contato direto com Divino por telefone e internet, o mesmo não tenho com muitos dos outros amigos que fiz em minha última visita em Janeiro. Essa reaproximação, ao lado de um interlocutor da comunidade, auxilia em muito a religação desses laços. Pela manhã também conheci o menino Caio, filho do amigo Fábio e de sua esposa (irmã de Divino), que assim foi batizado por conta de minha visita à aldeia em Janeiro. Uma homenagem que naturalmente me deixara muito contente. Esse, me parece, é um 
hábito bastante comum entre os xavantes que gostam de demonstrar o afeto com determinadas pessoas homenageando-as na escolha dos nomes. Cada vez mais me chama a atenção como, ao menos com os xavantes com quem mais tenho conversado, todo o imaginário em torno da "braveza" (com ênfase no aspecto "guerreiro" que implicaria numa seriedade "espartana") é constantemente desconstruído, em corriqueiras situações carnavalizadoras onde o riso se torna o elemento central do diálogo. Não à toa Divino vive, reciprocamente, se referindo a mim como "a'uwétoire", algo como "índio brincalhão", "xavante-palhaço", quase que como num duo clownesco em que ambos os "palhaços" são importantes na narrativa. Depois de visitarmos as casas que preparavam o churrasco de anta, nos dirigimos ao centro da aldeia onde Divino e César conversaram no idioma xavante com Valeriano (representante da outra metade da aldeia). Segundo Divino, a outra metade da aldeia preferiu que nós, waradzu (branco), não filmemos sua participação no ritual. Tenho a impressão que a influência política e a facilidade de trânsito adquirida pelo Divino, sobretudo por conta de sua trajetória com o audiovisual e a força de seu cinema na consolidação de uma espécie de defesa da cultura xavante, despertam, ao mesmo tempo, um grande respeito da comunidade como também um espelho a ser seguido por um grupo, ou liderança, que almeje o poder. Dessa forma, Divino (que, embora cunhado, faz parte

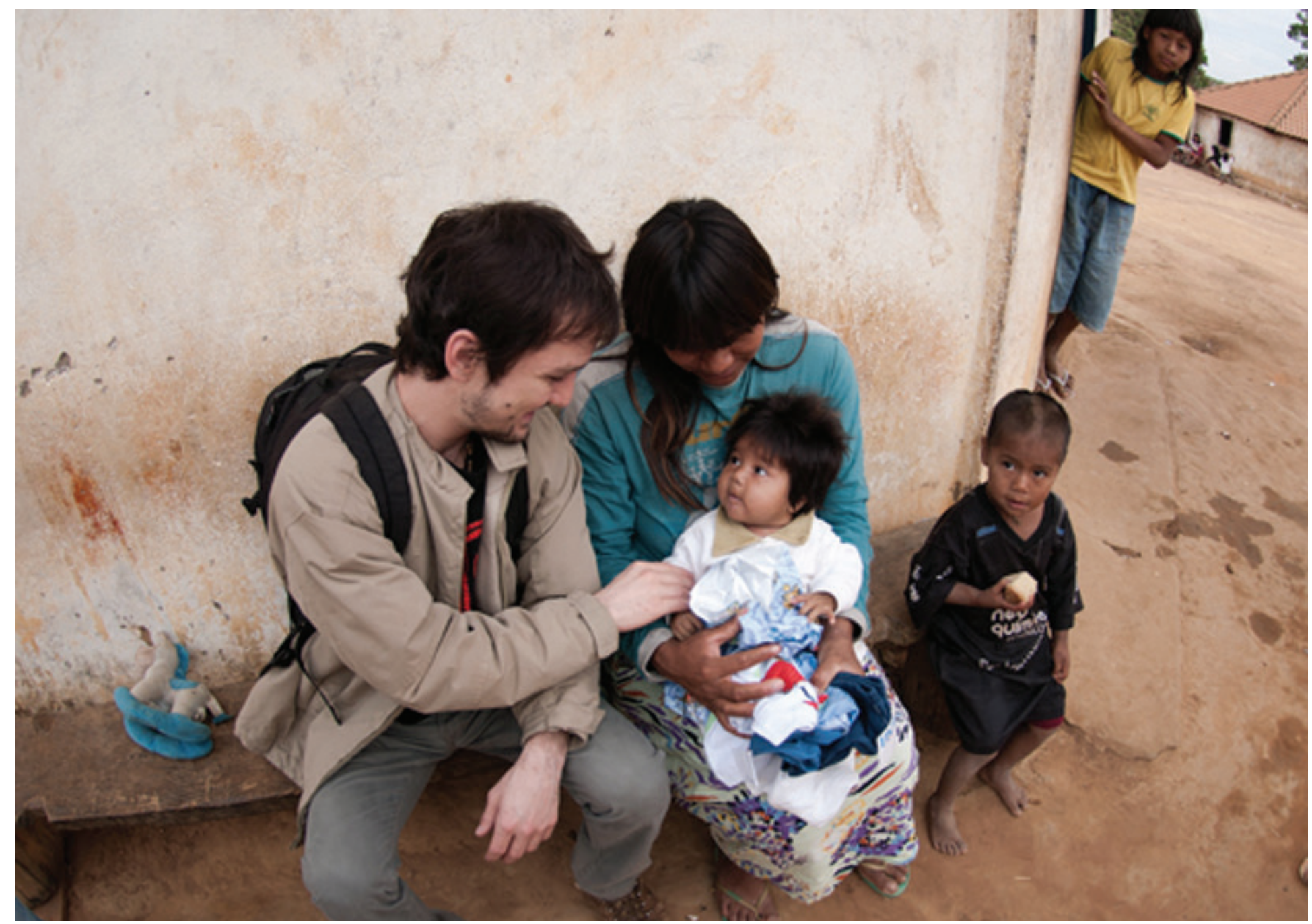

Foto 42. Caio Lazaneo e o "chará” Caio no colo de sua mãe (foto: Di Pannacci) 


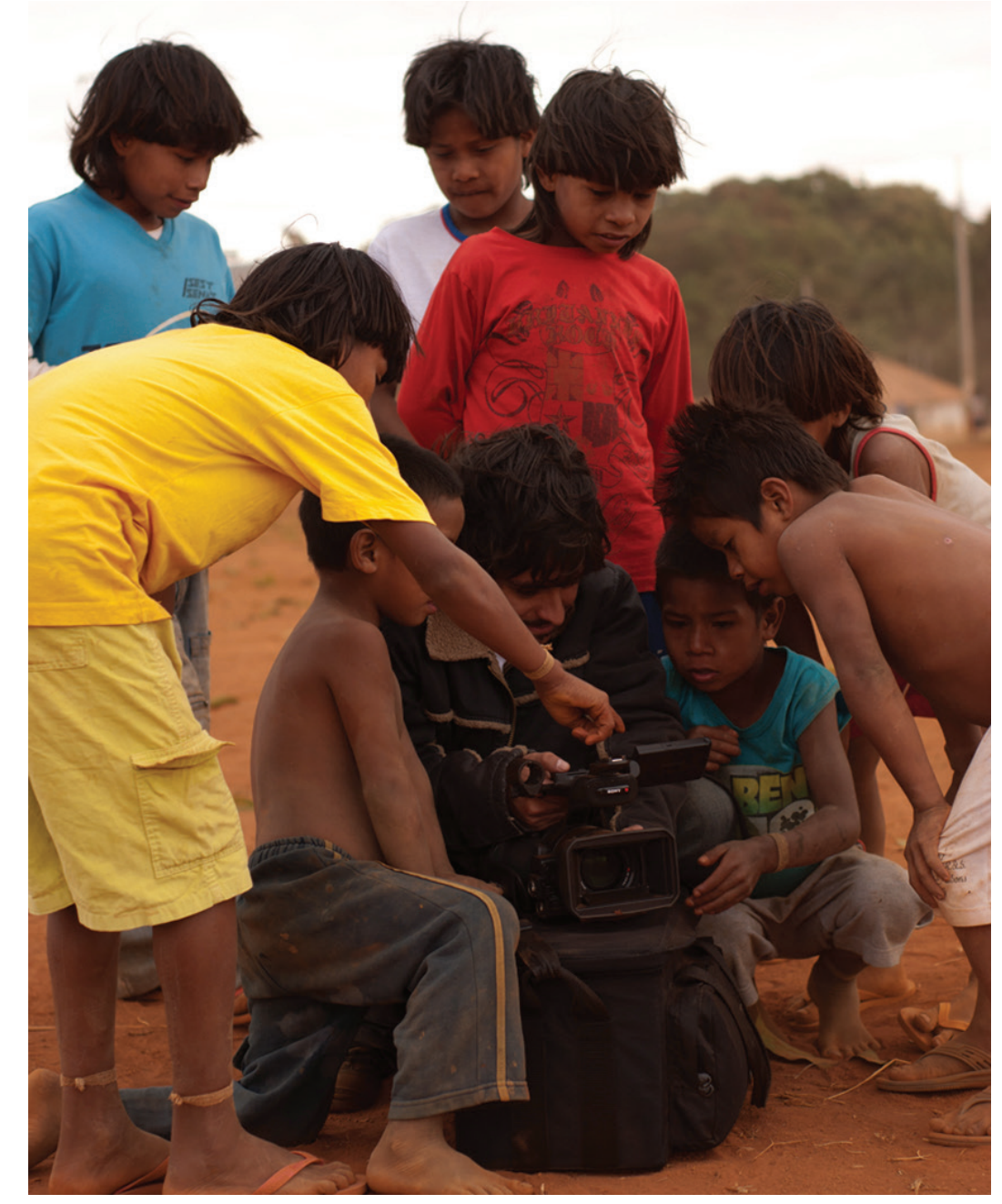

Foto 43. Crianças xavantes acompanham os registros do Wapté feitos por Di Pannacci (foto: Caio Lazaneo)

do grupo politicamente oposto de Valeriano) e nós, seus convidados, não conseguiríamos, nesse momento, uma fácil inserção na outra metade da aldeia que não reconhece Alexandre (pai de Divino), como seu cacique. Assim sendo, Divino nos sugere, como não poderia ser de outra forma, registrarmos o ritual apenas a partir da participação de uma das metades da aldeia. Pela tarde, tentamos filmar e fotografar a preparação das jovens mulheres para a corrida que acontece depois da grande caçada. $\mathrm{O}$ forte vento e a enorme quantidade de terra e areia que cruzavam a todo momento a aldeia, prejudicaram um pouco os registros fílmicos, em parte pelo vento causar grande ruído ao áudio e em parte pela "neblina" de terra prejudicar o que se pode compreender da imagem. Porém, em relação a fotografia, essa situação proporcionou fotos interessantíssimas, sugerindo silhuetas em meio às névoas de terra, que metaforicamente remetem à intrínseca relação do povo xavante com o sonho. Divino fazia o papel de noni (espécie de condutor da corrida que com uma "máscara" de palha de buriti é quem da a ordem às crianças alinhadas para começarem a correr) para crianças de uma metade, e Valeriano, o noni, para as crianças da outra metade. Quando um organizava suas crianças para iniciarem a corrida do centro de aldeia até o tronco que marca linha de chegada, o outro organizava sua fila para depois iniciar o mesmo processo. Filmei Divino falando sobre a corrida e o que ela representava e tentei repetir as mesmas perguntas para Valeriano (que aceitou, sorridente, ser filmado), assim como trechos da corrida. Depois de um exaustivo dia, a noite combinamos de registrar uma dança feminina que acabou não acontecendo devido a uma inesperada queda de energia na aldeia e na missão que fez com que as pessoas não saíssem das casas, algo que surpreendeu a mim e ao Di pois imaginávamos que, independente da energia elétrica, a dança aconteceria. 


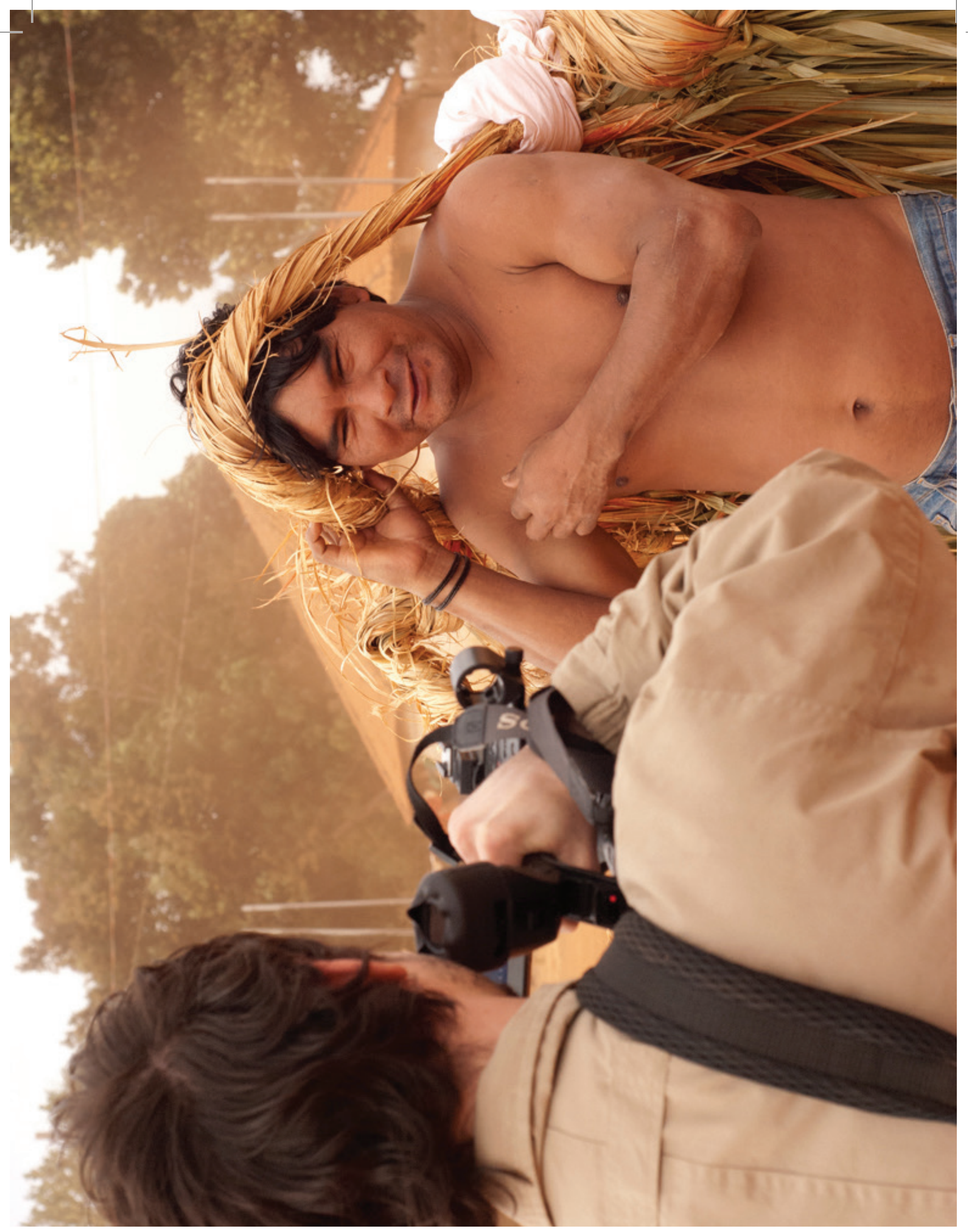




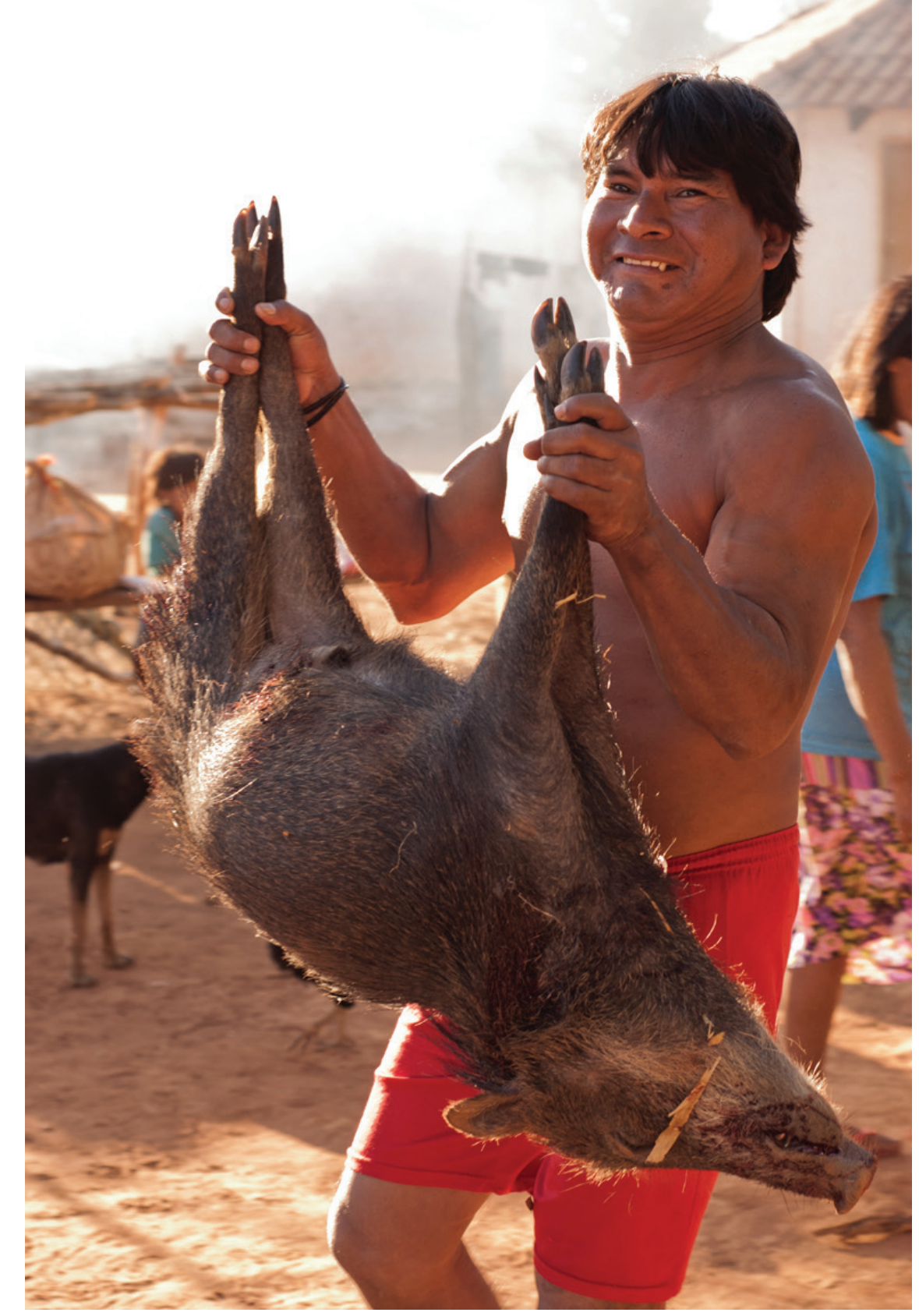

Foto 46. "Essa eu que matei” (foto: Di Pannacci)

falar. Por conta do clima um pouco tenso que fora criado, acabei eu mesmo não filmando esse encontro. Quando chegamos a aldeia, um dos primeiros tópicos que conversei com Divino foi sobre que caminho que seguiríamos no registro do filme e o que distinguiria o nosso trabalho atual (em termos de linguagem) do famoso filme "Wapté Mñoño: Iniciação do jovem xavante”, que Divino realizara em 1998. A ideia em comum é de que esse filme não deverá abordar somente o Wapté, mas também o conflito pelo qual passa a aldeia. Enquanto registrávamos depoimentos e cenas da preparação da corrida, encontrei Beto, Natal, José Carlos, Eliseu e Fábio, amigos que fiz na oportunidade da oficina de vídeo de janeiro. Todos mostravam-se muito felizes com a nossa presença. Enquanto conversávamos, um carro chegou com a caça e todos, repentinamente eufóricos, passaram a correr atrás. Dentro do pequeno veículo (um carro popular) estavam três xavantes - entre eles o ex-cacique Paixão - que desceram e abriram o porta-malas onde, para a alegria das pessoas ao redor, havia cinco queixadas abatidas pela tarde. Divino tratou logo de carregar uma e pedir a Rodrigo que o fotografasse - como um caçador que acaba de abater sua presa - repetindo eufórico com um sorriso no rosto: "Essa eu que matei". É engraçado notar que, dado sua função de cineasta, Divino não costuma realizar ou conduzir as práticas ritualísticas comum aos xavantes (como a caça por exemplo), mas sempre registrá-las. 
Junto deste carro, outros também chegaram com caças na mesma hora na aldeia. $\mathrm{O}$ alimento se espalhava pelos quintais das casas e espaços comuns, onde os homens mais velhos começavam a cortar os animais, separando os órgãos, o couro, a carne e as outras partes, ao mesmo tempo em que as fogueiras começavam a ser acesas para assá-los. Crianças, velhos, jovens e adultos saíam de suas casas e se reuniam em torno das palhas no chão, onde ficavam os animais. Cada qual contribuía da sua maneira, alguns apenas olhavam curiosos e contentes, outros buscavam madeira ou colocavam as partes dos animais para assar diretamente no fogo para depois retirar mais facilmente os pêlos. Filmamos e fotografamos bastante essa etapa e o diálogo da comunidade durante o processo. A grande quantidade de informação que tenho me deparado me deixa constantemente confuso, sobretudo em horas como essa quando repentinamente Divino não esta mais ao meu lado. Porém, acabo sempre encontrando algum conhecido que me auxilia na compreensão e interlocução necessária. Alguns amigos me convidaram para gravar a caçada durante a noite, no entanto por conta da falta de luz para o registro, combinamos de gravá-la na tarde do sábado. Depois disso, já bastante cansados, voltamos ao alojamento onde, depois da janta, não restava muita energia senão para uma noite reconfortante de sono.

Esse dias de $T_{s}$ 'rehipãri têm me colocado, novamente, em contato com uma vivência do senso communis de um cotidiano singular durante o trabalho de campo. A premissa da produção partilhada que desenvolvemos no Cedipp - e que acreditamos ser de evidente importância para o contexto de uma pesquisa acadêmica - parece transcorrer naturalmente entre os xavantes.

Foto 47. (da esq. para direita) Eliseu Tserenhomware, Di Pannacci, Sérgio Waiadzatsé, Fábio Tsitobrowe, José Marinoni Tsõpré, Caio Lazaneo, Beto Tseredze Wa'u’é, Natal Anhahö’a e Divino Tserewahú (foto: José Carlos Tsipatsé)

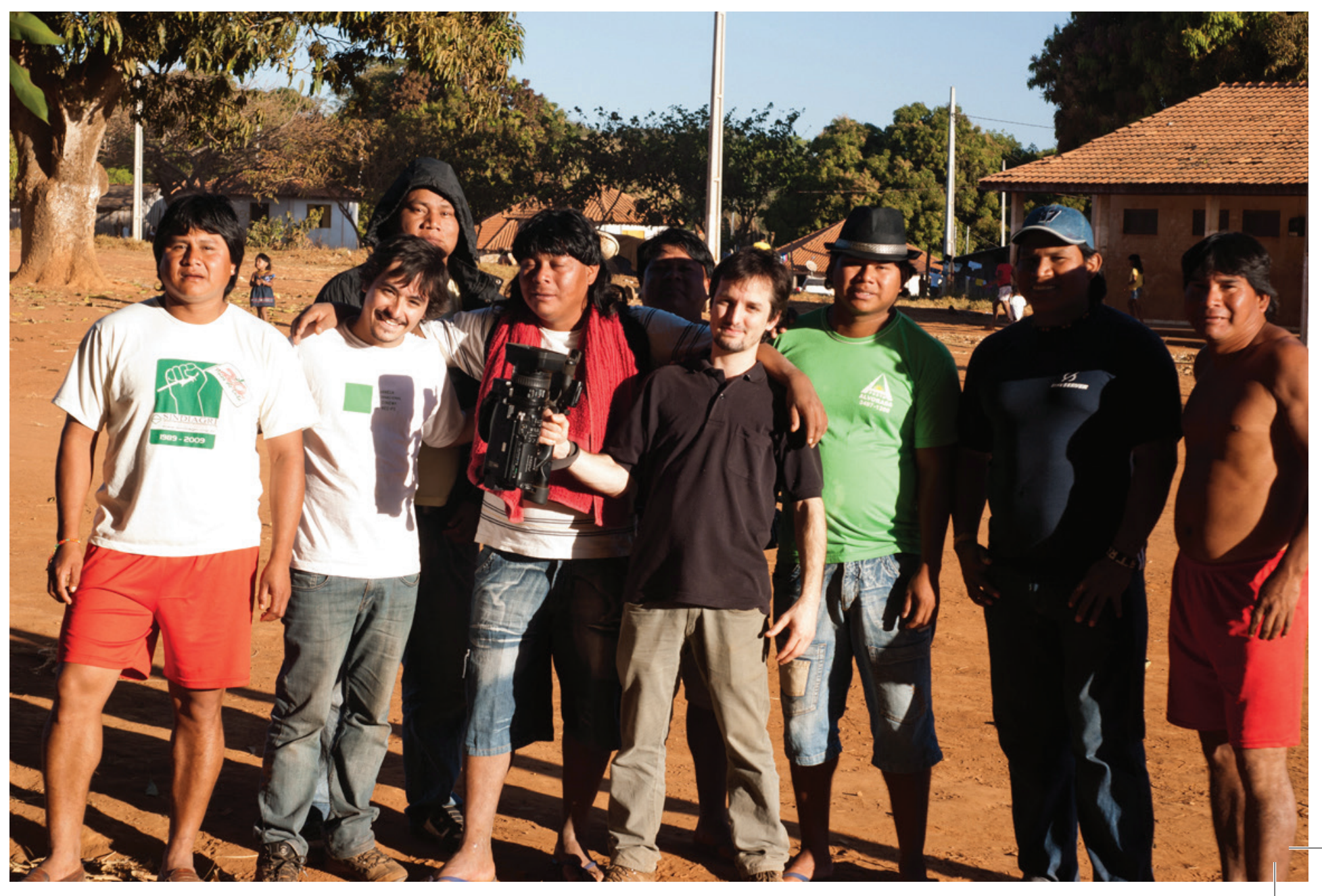


também me narrou que na noite anterior teve de "dar uma lição" em Tobias, filho de Augusto, que falava mal do cacique Alexandre, com palavras de baixo calão, por toda a aldeia. Reiterei a ele minha vontade de que tentemos registrar o diálogo da comunidade nas mais diferentes possibilidades e para isso recorrermos à interlocutores de ambos os lados. Divino, a princípio, corrobora com a vontade, mas receio de que apenas para me agradar já que não sei se gozará da liberdade ou mesmo vontade para fazê-lo. O clima tem ficado bastante tenso e receio de que conflitos mais agudos possam acontecer. Pela tarde, ainda quando conversávamos eu, Di, Natal, Eliseu e Divino, uma repentina correria na aldeia chamou a atenção. Ao chegar no Hoo (casa dos adolescentes) da metade do cacique Alexandre, anciãos e adultos inconformados e crianças curiosas entravam e saíam para ver os enfeites da dança do sol que haviam principiado a pegar fogo e que, segundo os amigos a quem perguntei, provavelmente teria sido causado por crianças da outra metade. Registrei esse momento e o diálogo dos adultos e anciãos dentro do Hoo. Segundo Divino, na manhã seguinte os anciãos dessa metade discutirão sobre o acontecido. Quando retornei ao alojamento, encontrei Valtércio que estava andando com seu irmão pela missão. Ele fora aluno da oficina em janeiro e me perguntou se eu poderia ajuda-lo a registrar o ritual. Por ele fazer parte da metade que considera Domingos como liderança, expliquei que seu próprio grupo não me havia permitido, mas que, entretanto, caso algum ancião permitisse não haveria problema em fazê-lo. Ele ainda me contou emocionado que sua filha havia falecido há pouco tempo, e que no filme que ele realizou junto com o grupo em Janeiro, durante a oficina de audiovisual, era possível vê-la filmada.

Os últimos dias dessa semana foram de grande intensidade. No sábado (06/08) chegaram à aldeia Rafael Coelho e Massimo Canevacci. Antes se imaginava, conforme Divino relatara por conta do que se ouviu na aldeia, que ambos registrariam a metade de Domingos no ritual, porém essa impressão não se confirmou, já que se tratou apenas de uma rápida visita. Apesar do pouco tempo que cá ficaram (apenas o dia de sábado até a tarde de domingo), foi muito bom conhecer Rafael - que inclusive fora iniciado no ritual Wapté durante sua pesquisa de mestrado no Multimeios da Unicamp tendo morado durante quatro meses em Sangradouro - e também Massimo, que além de ser uma referencia constante para minha pesquisa, é uma pessoa muito simpática e contagiante. Ele tem uma proximidade e amizade muito grande com Domingos. Juntos viajaram para Itália em eventos organizados por Massimo. Foi a primeira vez que pude encontrar Domingos, que veio à missão no domingo de manhã ao encontro de Massimo. Domingos é extremamente comunicativo e se mostrou muito afável com Massimo. $\mathrm{Na}$ conversa que participei entre os dois, Domingos não falou sobre os motivos da divisão política da aldeia. Em um momento, que destaco, elogiou muito os filmes de Divino, o que me pareceu muito sincero já que ambos não são politicamente aliados.

Conversei bastante com Rafael sobre a proposta da produção partilhada de conhecimento do Cedipp, e como o presente registro do Wapté se insere nela, assim como a relação da temática com a comunicação digital. Em janeiro, quando cá estive por conta da oficina, fiquei amigo de dois de seus ex-alunos da Universidade Federal de Goiás, Luiz e Bruno do coletivo Magnífica 
Mundi que, por sinal, também tem projetos bastante interessantes com comunidades. Também chegaram no sábado à aldeia, um casal muito simpático de italianos, Elisa e Francesco. Elisa estuda a educação no contexto xavante em seu curso de pós-graduação em Padova.

Após o jantar, eu, Rodrigo, Rafael, Massimo, Elisa, Francesco e “irmã” Necinha, continuamos no refeitório a conversar com um evidente entusiasmo que se faz presente em pessoas que se encontram pela primeira vez e desejam compartilhar muitas experiências. É uma pena que Rafael e Massimo tenham passado tão rápido por aqui. No domingo pela tarde seguiram para a aldeia bororo Meruri.

Os dias de ritual seguiram tão calmos que Divino programou, no domingo, uma ida para uma pousada de "waradzus" (brancos), amigos de seu pai, que fica próxima da aldeia. Domingos esteve na pousada e conversou com Divino. Segundo Divino, Domingos havia autorizado que também gravássemos sua metade no ritual, porém a comunidade que ele representa continuou a não querer. Deste modo, continuaremos a filmar o que acontece no ritual da metade do cacique Alexandre, porém, na medida do possível, também trataremos da temática da divisão através de diferentes vozes. Entre a terça-feira e a tarde da quarta-feira as coisas continuaram bastante "mornas" na aldeia, porém na noite da quarta uma tragédia mudou completamente o panorama que corria até então. Havíamos combinado um encontro com Divino - que passaria nos buscar no alojamento as oito e meia da noite - para que fossemos a sua casa. O tempo passou e estranhamos seu incomum atraso. Por volta das dez horas, visivelmente abatido, ele nos chamou na porta. Com uma voz baixa e abalada nos contou que o rapaz Pedro Afonso Warâi' ró, de quem eu havia sido professor na oficina de janeiro, havia acabado de falecer vítima de atropelamento na rodovia federal que passa muito próxima à aldeia. Divino nos falou com temor de que a aldeia estaria na iminência de uma guerra fraticida, já que o motorista que atropelou Pedro era também xavante, porém cada qual pertencente a uma metade política da aldeia. Ficamos bastante temerosos já que Divino também relatou, preocupado, que as famílias preparavam armas de fogo e outras armas para um combate. Divino já havia nos confirmado que o motorista era xavante, porém segundo ele ainda pairava na aldeia uma dúvida sobre quem de fato o era. A recomendação nos transmitida foi de que ficássemos o máximo possível na missão, evitando absolutamente idas à aldeia. Depois que Divino fora embora, achamos prudente que fossemos avisar nossos amigos Francesco e Elisa, que costumavam caminhar até a aldeia nas manhãs e que o evitassem de fazer por conta do ocorrido. Algo que também me preocupa muito neste novo fato inusitado, é a importância política que Divino tem para a aldeia e, consequentemente, qual o desdobramento que isso poderá ter. Dias antes deste ocorrido ele havia levado um soco abaixo do olho - que lhe cortou a pele - ao tentar separar uma briga. Deste modo, não sei até que ponto, por conta do seu status, ele poderia ser um alvo de represálias e hostilidades. Na manhã seguinte, Divino nos deu um novo panorama mais tranquilizador. Segundo se ficou sabendo, Pedro acompanhava outros rapazes xavantes que, embriagados e atrás de mais bebida, colocaram obstáculos na rodovia para cobrar os motoristas que por lá transitassem. Essa espécie de pedágio é uma prática relativamente comum em rodovias que atravessam extensas áreas de 
reservas indígenas, por vezes por questões políticas e territoriais (como forma de protesto ao desrespeito em relação à demarcação de terras, por exemplo) ou, como neste caso, por um motivo aparentemente fútil. Segundo Divino, outros quatro rapazes voltaram para a aldeia deixando Pedro sozinho e, não se sabe de que forma, o carro o teria atropelado. De acordo com Divino, por já ser noite, o motorista (que agora era de conhecimento de todos) não o teria enxergado e nem notado o atropelamento por conta da alta velocidade que se encontrava e dos obstáculos na pista, acreditando ter atropelado um galho. A explicação acalmou as animosidades de ambos os lados. O velório e enterro aconteceram ainda na manhã e o luto instaurou um enorme silêncio na aldeia, onde antes era comum muita movimentação e sons festivos. Pouco temos feito nos dias que se sucedem o luto. O ritual nas duas partes foi interrompido. Nossa volta terá de ser adiada para que consigamos acompanhar até o último dia do ritual. Hoje aproveitamos para visitar Paulinho na aldeia bororo de Meruri, que dista aproximadamente $100 \mathrm{~km}$. de Sangradouro a caminho de Barra do Garças. Não via Paulinho desde nossa viagem para a aldeia karajá Fontoura para registrar o ritual HetoHokã. Foi uma ótima oportunidade para matar a saudade de um amigo e também conhecer sua aldeia. Pela tarde o Padre Uchoa, que estava em Meruri desde antes da década de 70 - inclusive durante o famoso caso quando Simão Bororo e o Padre Rodolfo Lukenbein foram assassinados a mando de fazendeiros que disputavam terra - nos mostrou o Centro de Cultura da aldeia explicando muitas particularidades do universo bororo. Registrei todo seu percurso e apresentação sobre aspectos da cultura bororo, sobre os quais ele demonstra grande familiaridade advinda de alguém que há 50 anos por lá vive.

Apesar de ter sido instituído o luto de 7 dias em Sangradouro, o ritual, que possui um prazo limite para o término, reiniciará antes do fim desse período. Divino disse que logo no sábado uma metade retomará a caçada e a outra no domingo. Essas datas foram decididas pelos anciãos das duas partes afim de que o ritual termine primeiro em uma e depois na outra parte, para que se evite acontecer duas danças do sol no mesmo dia, algo que poderia desencadear reações imprevisíveis de ambas as partes. A tendência é de que, a partir da semana que vem, a aldeia toda esteja novamente envolvida com as etapas finais do ritual que se iniciam tão logo encerrado o período de caça, porém num ritmo mais acelerado, em que os acontecimentos se tornam muito mais intensos, por conta da proximidade do término do Wapté.

Por conta do luto, o sábado transcorreu com uma tranquilidade fora do comum. Passei a tarde conversando com Divino e ajudando-o na decupagem do material bruto de um ritual fúnebre bororo ocorrido em 2009 na aldeia Gomes Carneiro. O evento fora filmado por Paulinho e por Sérgio Sato, financiado pelo Museu das Culturas de Campo Grande. Divino, como funcionário do museu, esta preparando 100 cópias do material, para serem entregues à aldeia bororo. Tenho notado que seu humor vem oscilando nos últimos dias, muito provavelmente por conta da tensão que envolve a divisão da aleia, o recente acidente e o ambiente festivo que pressupõe o ritual. 
Ainda no final da tarde de sábado combinamos que as gravações recomeçariam na tarde do domingo, com o começo da preparação das máscaras com palha de buriti. Aproveitei a manhã do domingo para organizar pensamentos e leituras assim como, na intenção de observar um fenômeno cultural típico de Sangradouro, ir à missa na capela da missão onde, aos domingos, são executados os cânticos cristãos na língua xavante. Tem sido interessante observar as inter-relações no cotidiano dessas duas comunidades na terra indígena de Sangradouro. De um lado o povo A'uwé de Tsö'rehipãri e do outro a missão salesiana. Uma relação que, me parece, nem sempre é muito tranquila, permeada por afinidades e dissabores, como tão bem demonstrado por Divino em seu filme sobre Sangradouro (Tsö'rehipãri), que conta a história da formação da aldeia e sua relação estreita com a missão salesiana. De qualquer modo, a despeito de minha divergência ideológica, é inegável que o trabalho dos salesianos em algumas regiões foi de vital importância para a sobrevivência de algumas etnias, ou ao menos de uma porção representativa de algumas delas (que estiveram na iminência de desaparecer enquanto grupo ameaçadas por doenças, perda de terras, etc.) muito embora, por conta disso, tivessem de aparentemente se "sujeitar" às práticas evangelizadoras. Pela tarde, antes da ida à aldeia para recomeçar a registrar o ritual, tivemos uma boa surpresa. Quando retornávamos do caminho do refeitório para o alojamento afim de buscar o equipamento, encontramos o mestre Adalbert Heide, com quem temos almoçado e jantado todos os dias na última semana e meia, e que parecia estar nos esperando. Perguntou, assim, se gostaríamos de conhecer seu quarto/estúdio. Eu já havia conhecido quando cá estive em Janeiro, ocasião em que ele me apresentara alguns de seus documentários entre os xavantes, porém, naquela oportunidade o papo havia sido muito rápido, e eu não havia tido a oportunidade de registrá-lo. Dessa vez, imediatamente perguntei se poderia filmar o encontro e ele não se opôs. O humor do mestre Heide é bastante conhecido em Sangradouro, onde é tido por muitas pessoas (tanto salesianos quanto xavantes) como turrão e uma pessoa de difícil acesso. Acredito que seu problema auditivo contribua muito para isso, isolando-o ainda mais e dificultando a comunicação com outras pessoas. Entretanto, na tarde desse domingo, ele parecia estar de muito bom humor e nos apresentou 4 de seus filmes, e uma infinidade de cenas de outros. Mostrou, inclusive, o "filme proibido do Wai'á Rini", que ele havia feito na década de 80 tendo também filmado as partes proibidas do ritual. Segundo ele, hoje em dia, os xavantes não permitem nem mesmo que os próprios xavantes registrem essas etapas proibidas do ritual e o que acabávamos de ver seria "privilégio de poucas pessoas no universo". Nesse momento solicitou que eu desligasse minha câmera. De fato, foi um privilégio conhecer um pouco mais de um incrível acervo apresentado pela própria pessoa que, com uma disciplina espartana, o registrou e catalogou exaustivamente. Ainda antes de nos despedirmos, Heide se dispôs a gravar alguns de seus filmes para que eu os levasse comigo. Pela tarde, finalmente retornamos à aldeia. Baixada um pouco a poeira causada pelos ânimos acirrados em torno das confusões do últimos dias, estávamos enfim de volta. Logo quando chegamos, porém, Divino que brincava de noni, pediu que ficássemos mais próximos aos velhos no centro da aldeia, já que "bêbados da outra parte" poderiam se irritar por essa metade já ter recomeçado 
o ritual. Gravei alguns diálogos entra anciãos no preparo da cesta, bakité, de palha de buriti que transportará as carnes da caçada e também o começo da preparação das máscaras que serão usadas pelos wapté. Quando Divino não estava por perto, recorria a José Carlos Tsipatsé, como interlocutor, para que dialogasse, na língua xavante, com as pessoas da comunidade que participavam dessa etapa. Também deixei que José Carlos, que fora meu aluno na oficina de Janeiro, filmasse os preparos.

Uma outra questão que tem me despertado grande atenção, não só nesses dias de Tsö'rehipãri, diz respeito ao riso na cultura xavante, que noto com frequência quando da minha presença no campo ou mesmo nos encontros em outros contextos com Divino e outros xavantes. Ao menos entre os amigos com quem tenho mais proximidade na comunidade, é muito frequente que aconteça o que Bakhtin chamaria, em sua análise do universo da cultura popular na obra de Rabelais, de um "riso ingênuo", característico do baixo corporal grotesco liberador e regenerador, que consegue sempre ser despertado em diálogos jocosos, aparentemente pouco elaborados, que remetam ao baixo corporal. Essa questão tem sido essencial para uma efetiva proximidade no diálogo com os interlocutores na comunidade pois, via de regra, é a partir do riso que se iniciam as tratativas para as questões mais simples até as que impliquem maior seriedade. Não a toa, constantemente sou chamado pelos meus amigos de cá de "a'uwétoire", palhaço xavante ou índio brincalhão, numa relação de reciprocidade em que também os que assim me chamam elaboram, a seu modo, táticas do riso, onde as coisas de certo modo tendem a caminhar para o "Wato itsiwadze" - frase que desperta um riso efusivo sempre que repetida e que me fora ensinada em Janeiro -, no português algo como "Não estou nem aí".

Foto 49. Adalbert Heide mostra seus filmes sobre os xavantes (foto: Di Pannacci)

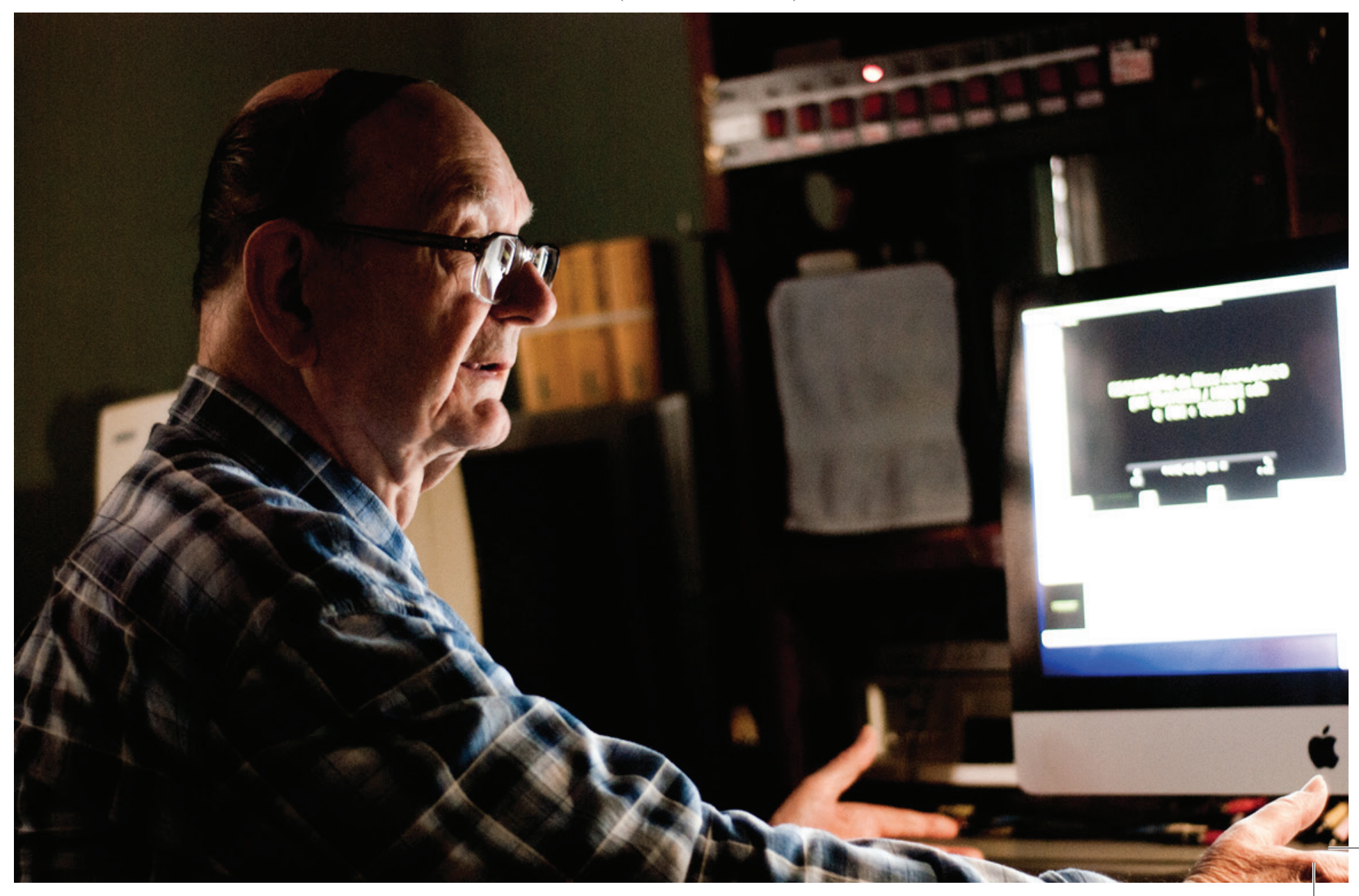


Um pequeno impasse ocorreu pela manhã. Combinamos que Divino nos encontraria no alojamento às 5 da manhã para que prosseguíssemos até a aldeia afim de filmar o começo do transporte da caça pelos waptés. Ele não apareceu no horário combinado e como eu estava exausto da noite anterior, em que fiquei até às 3 da manhã na tentativa de alterar meu vôo de volta, acabei voltando a dormir. Às 6 e 20 da manhã ele apareceu muito apressado e, assustados, nos aprontamos às pressas para correr até a aldeia. As coisas por lá já haviam efetivamente se iniciado. Sérgio, seu sobrinho e aluno da oficina de Janeiro, já registrava com a outra câmera e assim que cheguei passei a registar com a minha. Tenho percebido que algumas etapas do ritual acontecem de modo demasiadamente rápido e em diferentes lugares, algo por vezes confuso e bastante complexo aos meus olhos de waradzu (branco), ainda que tendo tantas vezes revisto

Foto 50. José Carlos Tsipatsé filma preparo de baktés (foto: Di Pannacci)

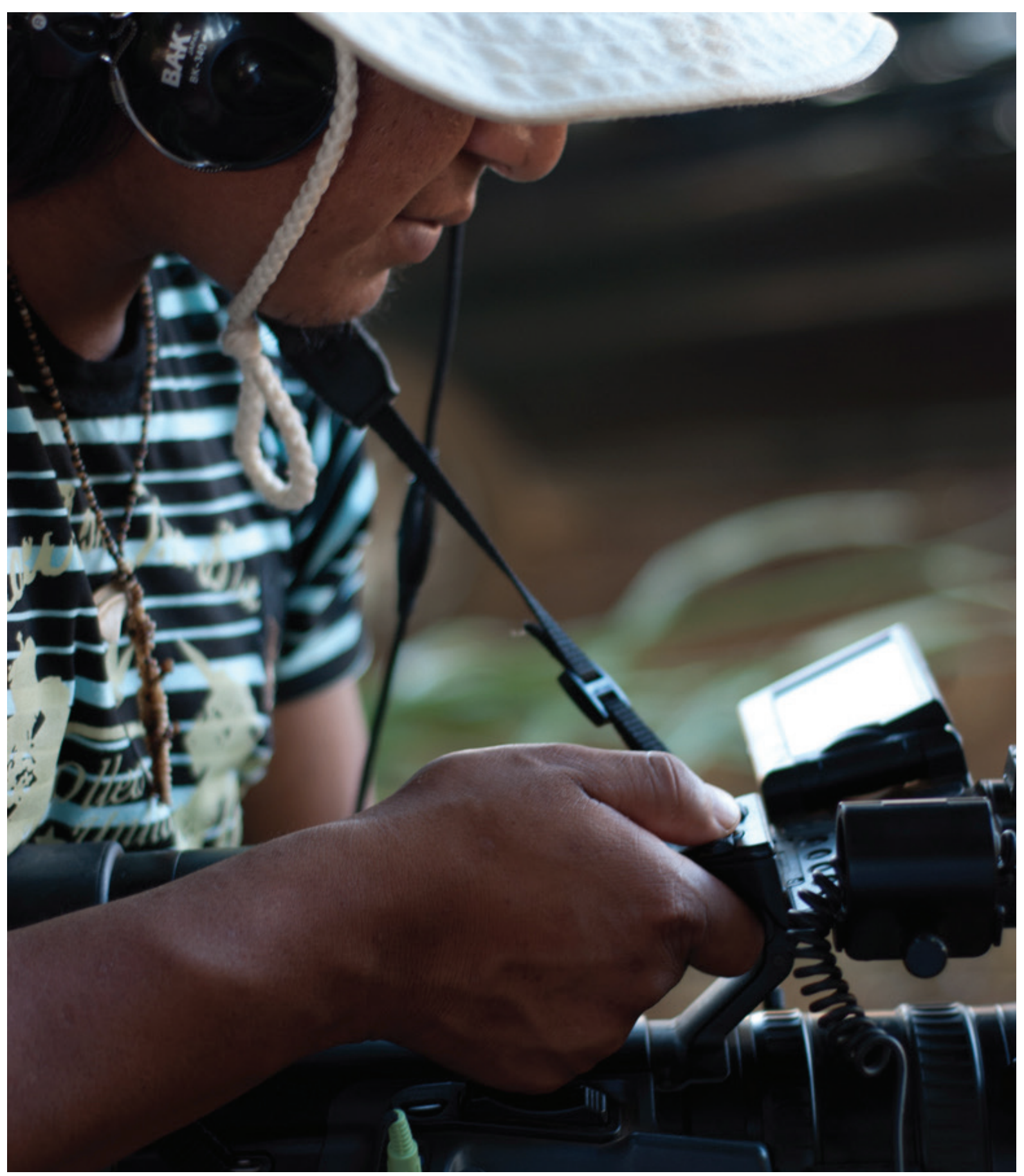




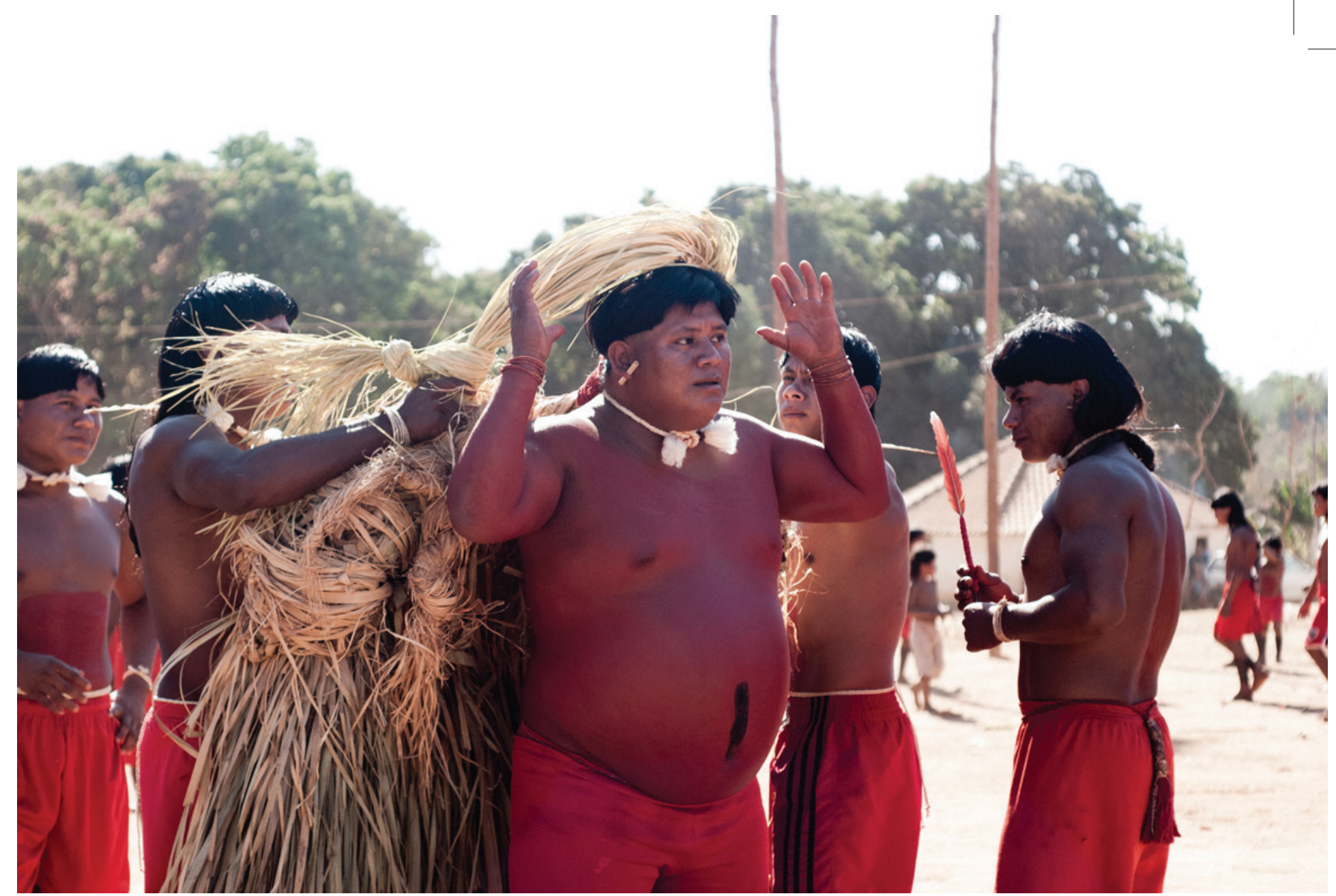

Foto 51. Noni vestindo a máscara (foto: Caio Lazaneo)

cenas de waptés passados, conversado e tomado notas com Divino. Pela manhã, ao fim das gravações, conversamos sobre a dinâmica da equipe. Segundo Divino, Sérgio não havia capturado partes que ele considerava importante nessa etapa, algo que também havíamos perdido. De fato não há como atribuir a culpa a alguém no acontecido, entretanto no diálogo que se seguiu com Divino, fiz questão de pedir desculpas e de salientar de que acredito que a equipe deveria ter uma unidade. Divino tem incentivado que outras pessoas da aldeia, como José, Sérgio, César e Natal, façam os registros no lugar dele, porém esse fluxo parece causar algumas vezes uma falta de sintonia, ainda que, para mim, seja uma experiência interessantíssima do ponto de vista da partilha do filme, que fica assim não apenas centrado na figura do "cineasta indígena" mas em uma diálogo de interlocutores audiovisuais, em uma comunidade, expressando uma forma de produção de conhecimento. Outra coisa que incomodou muito Divino nas cens perdidas foi o fato de que, no último Wapté que ele registrou, também não havia conseguido filmar algumas partes da mesma etapa, o que lhe rendeu uma bronca dos velhos, perenes guardiões das etapas ritualísticas e que sabem, assim, quais são as cenas de maior importância. Nesses momentos, a comunidade, principalmente na figura dos anciãos, mostra que além de ser filmada sabe também filmar, ainda que não precise manusear a câmera. Eu também chamei a atenção para a dificuldade que tenho tido de julgar o que deve ser registrado no momento em que as coisas acontecem (quase sempre de modo efusivo). Por não dominar o idioma xavante, tenho dificuldade em compreender o teor das conversas e poder assim julgar, minimamente, o que deve ser prioritariamente registrado. Partes ritualísticas como danças, diálogos e falas dos anciãos acontecem paralelamente, o que torna a decisão do que enquadrar bastante difícil. Entretanto, a mudança conceitual pela qual passamos na busca de uma produção partilhada, em lugar de uma autoria rígida e definida, expressa a possibilidade do enquadramento no além- 


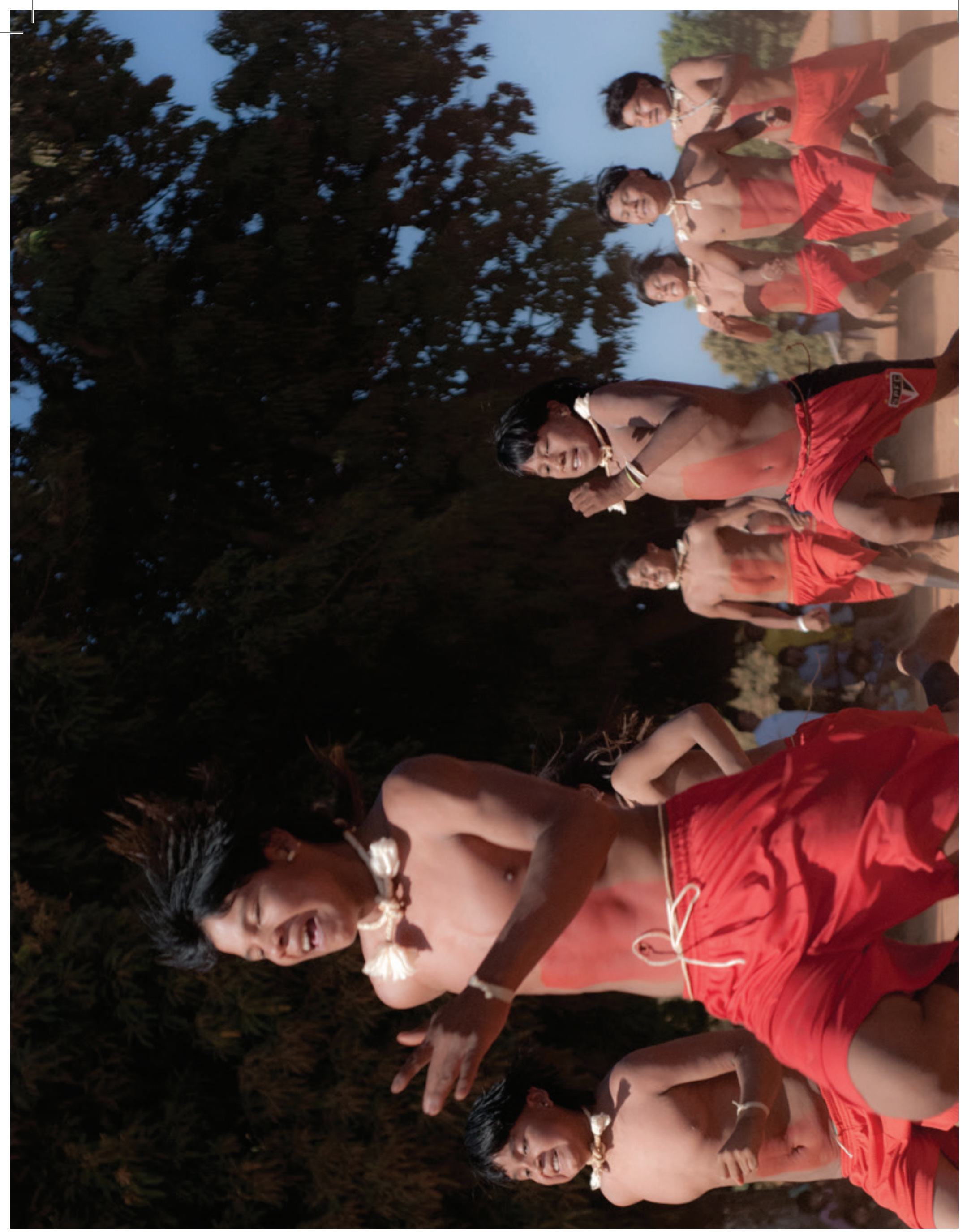




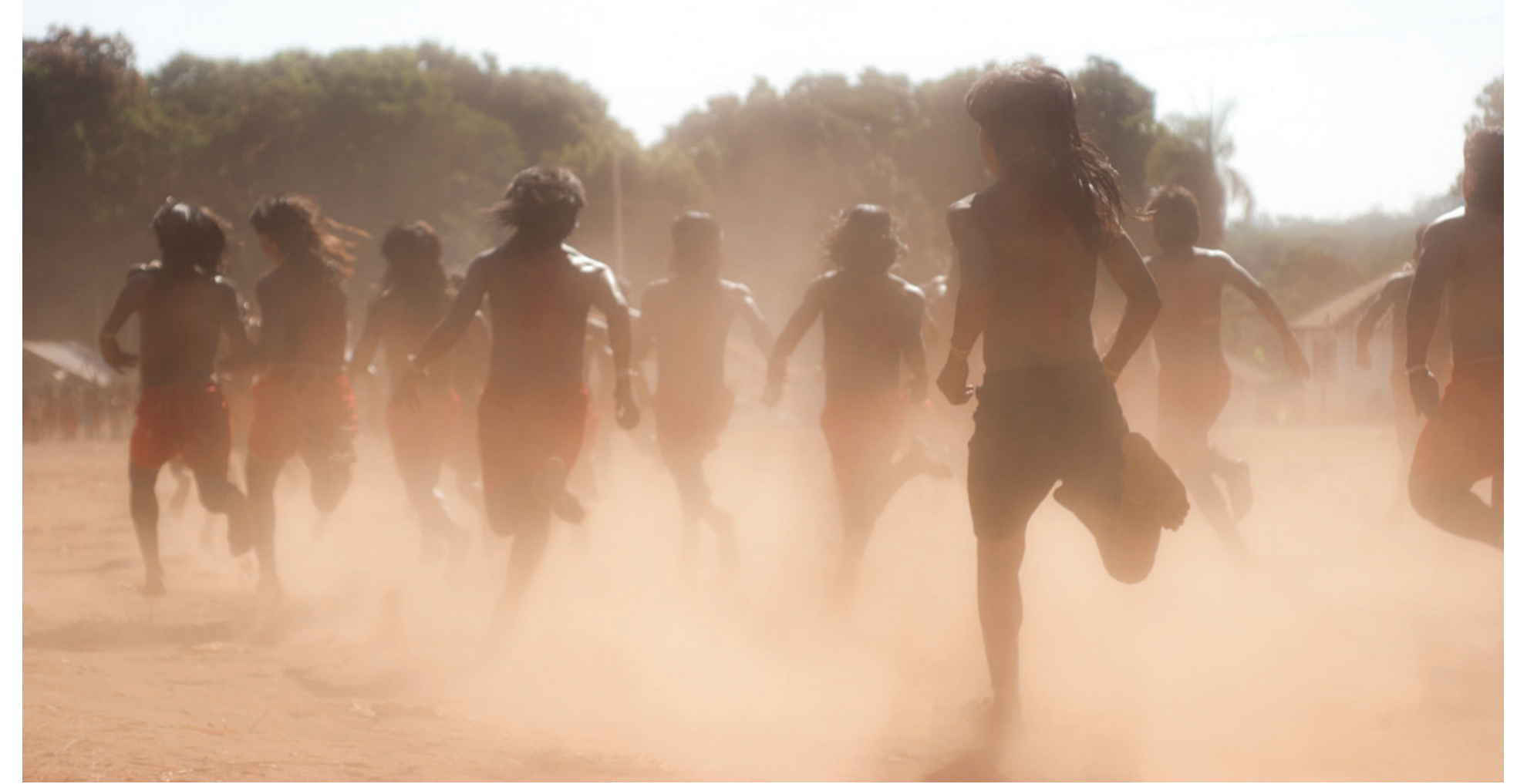

Foto 53. Corrida dos waptés (foto: Di Pannacci)

quadro, com a participação efetiva da comunidade no processo fílmico. A experiência do que se passou pela manhã serviu também para eu solicitasse ao Divino um pouco mais participação na sua "interlocução". O resto da manhã continuei a auxiliá-lo na decupagem do material do funeral bororo. Já na parte da tarde as corridas dos waptés se iniciaram em caráter oficial com os jovens dos subgrupos se enfrentando na pista que vai de um canto da aldeia à outro e que os xavantes, exímios corredores, apreciam muito. Registros dos corredores, anciãos, jovens, crianças e a polifonia de olhares de Tsö'rehipãri. Por fim, jantamos e fomos dormir cedo já que no dia seguinte as coisas começariam ainda mais cedo.

Acordamos às 4 da manhã e chegamos na aldeia meia hora depois. Filmamos o começo da preparação das máscaras dos waptés que são confeccionadas por seus parentes numa clareira, afastada da aldeia, em meio à mata. Dessa vez a equipe (uma das câmeras comigo e a outra com Divino), agiu em perfeita sintonia e conseguimos realizar bons registros. Di também tem feito excelentes fotos do processo. Com um pouco mais de liberdade e incentivo de Divino, passei a entrevistar as pessoas no idioma xavante (ao menos as perguntas iniciais) por notar que todas as vezes que iniciava o diálogo em português, havia uma dificuldade de comunicação. Não que o português não seja bem falado e entendido, mas visivelmente as respostas transcorrem com maior naturalidade quando o diálogo se inicia no xavante. Divino me guiava sobre que perguntas deveriam ser feitas e me ensinava como pronunciá-las. Deixaremos com a comunidade cenas belíssimas desse jornada. Na hora do almoço encontramos o casal italiano de amigos, Elisa e 


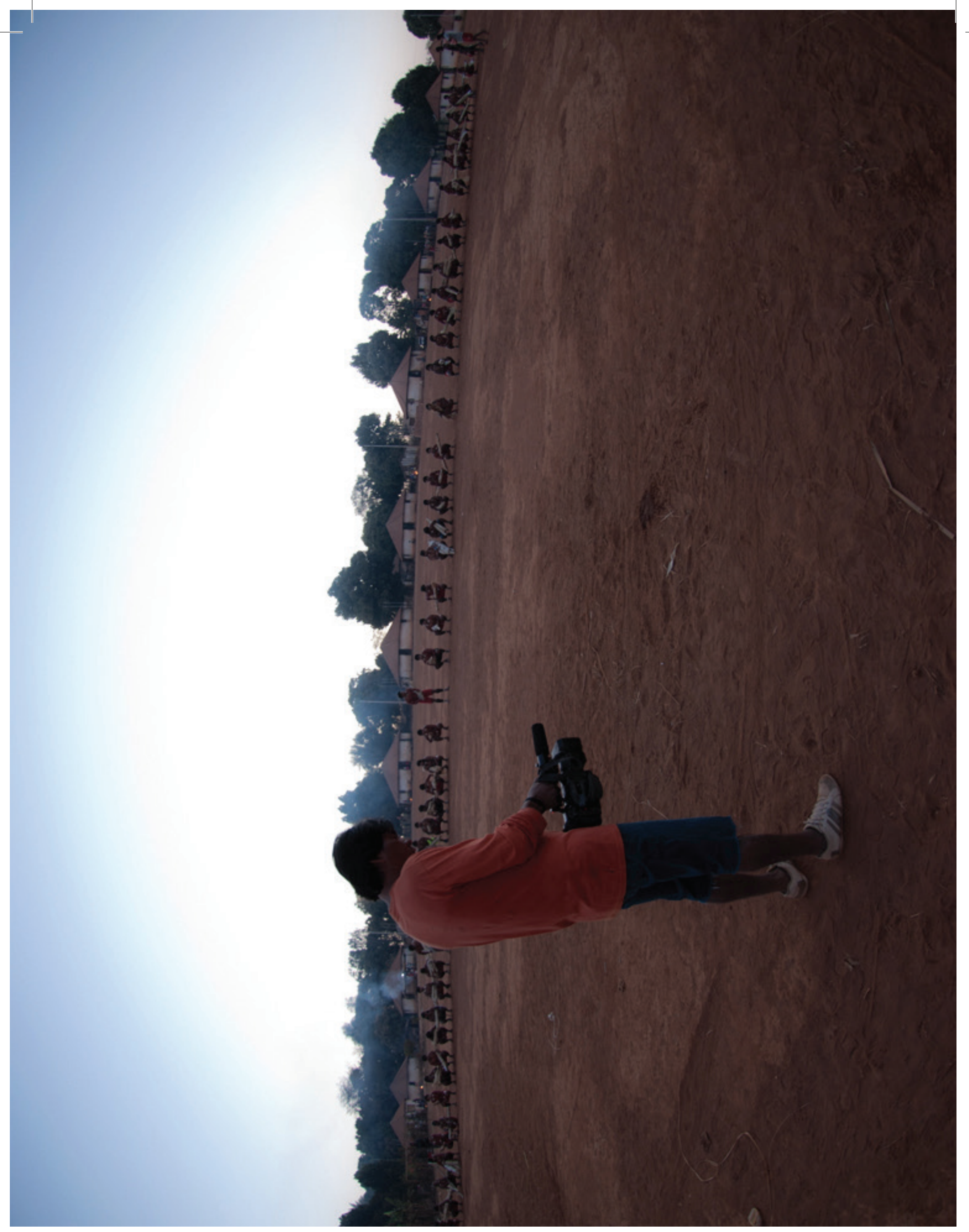




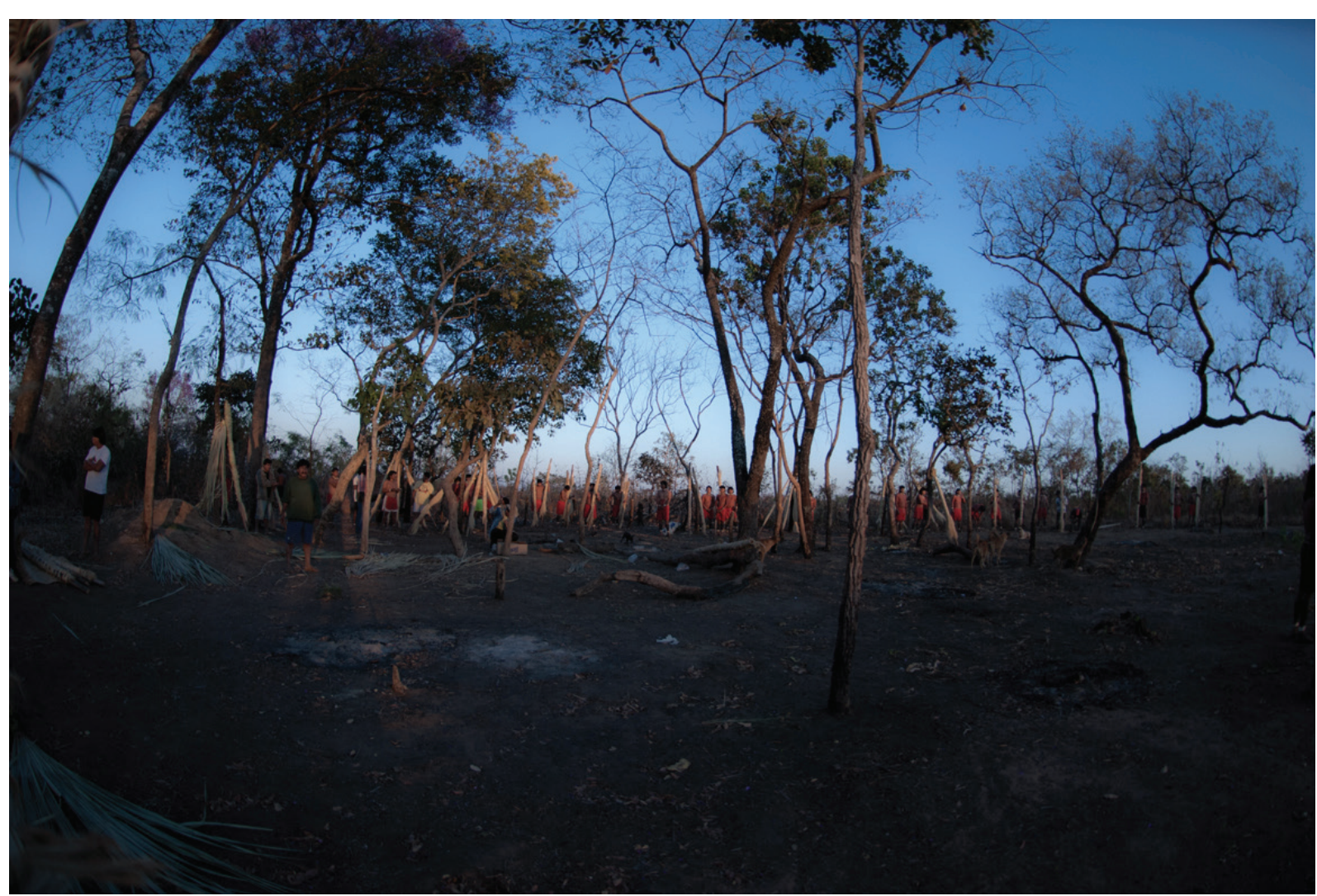

Foto 55. Preparação das máscaras dos waptés na clareira (foto: Di Pannacci)

Francesco, que acabavam de retornar de Poxoréu. Elisa demonstrou vontade de ir conosco até a clareira na mata onde as máscaras estão sendo feita e ficamos de verificar a possibilidade de que isso acontecesse já que nós sabíamos que, ao menos às mulheres xavantes, não poderiam ir ao local. Essa impressão se desfez já que Elisa fora autorizada por um ancião a seguir conosco. Pela tarde tive um diálogo interessantíssimo com Divino (devidamente registrado) sobre, dentre vários assuntos, a opção, que ele pretende levar adiante nesse filme, de não aparecer efetivamente nas gravações (algo incomum para quem conhece suas produções), seja realizando as perguntas, seja propriamente filmando. Meu ponto de vista é de que grande parte da força narrativa de seus filmes nasce justamente desse diálogo reflexivo e notadamente sincero com sua comunidade. Acredito que a questão da divisão, além de outros fatores externos, estejam influenciando para que, me parece, ele conceba um produto pretensamente mais "neutro", palavra que, embora não tenha sido por ele usada, é uma interpretação minha que, sobretudo em relação ao ritual, parece requisitar uma implícita necessidade "objetiva" ao filme. De qualquer modo, o diálogo foi muito interessante e enriquecedor para o trabalho conjunto. Passamos a tarde registrando e entrevistando os personagens durante a confecção das máscaras. O processo deve durar 3 dias e, na noite do último dia, precisaremos dormir na clareira para que, pela manhã, acompanhemos o caminho de volta das máscaras à aldeia que as aguarda ansiosamente.

Pela manhã registramos a continuação da preparação das máscaras dos waptés por seus parentes. Nessa etapa, os homens pintam algumas das partes das palhas com bastante urucum, deixando-as com um vermelho bastante forte e imponente. Todos os homens que participam diretamente dessa etapa têm de pernoitar na clareira junto das máscaras durante os três dias. Quando lá estávamos pela manhã, o encontro parecia ter um clima bastante fraterno, como uma extensão do hoo - casa que os jovens têm de passar 7 anos durante a preparação para a vida adulta - com frequentes risos, brincadeiras e música entre velhos conhecidos. Divino me relatara que Ticiano - um xavante que costumeiramente se encontra embriagado -arrumou confusão na noite anterior na clareira tendo levado inclusive alguns sopapos, algo não raro por 
öwawe) - e depois o resto dos waptés em grande ou pequenos grupos (em algumas largadas 15 ou mais jovens em outras 4 ou menos jovens disputam a corrida). Ao final da corrida, um grande círculo com os padrinhos dos nozâ'u, os etepa, dançam e festejam. Surpreendentemente, quando eu filmava o círculo de perto, Natal e Eliseu, dois dos meus grande amigos daqui, deram-me as mãos e puxaram-me para a dança com eles. Desde o começo dessa viagem, conversávamos brincando de que eu e Rodrigo seriámos etepa - por conta de nossa faixa etária - o que também nos oporia ao grupo do Divino, tirowá, que durante o ritual são amistosamente "inimigos". A brincadeira, de fato, se confirmava de alguma maneira já que eu estava sendo por eles convidado a participar de uma dança circular bastante particular. A experiência fora muito gratificante e mesmo com a dificuldade rítmica consegui repetir seus passos e algumas partes de seus cantos. Finda a dança, a equipe conversou descontraidamente sobre o dia de trabalho já planejando o seguinte, em que as gravações se iniciarão às 5 da manhã, quando nos encontraremos para registrar a saída das máscaras dos tébé da clareira para a volta à aldeia.

Hoje tivemos certamente um dos dias mais exaustivos desde nossa chegada. A rotina começou logo cedo, por volta de 5:30 da manhã, quando fomos à clareira filmar o término da preparação das máscaras e a saída para a aldeia. Tenho colhido muitas entrevistas, com ajuda de Divino que formula as perguntas e me ensina como e em que momento fazê-las, processo esse muito enriquecedor. No meio da manhã, com o término da preparação das máscaras, os tébés antigos (aqueles que já o foram em Waptés passados) começaram a ser pintados para depois levarem as máscaras para as casas dos novos tébés. Essas transições das etapas costumam acontecer de modo rápido, exigindo agilidade para não deixar passar algo importante. Depois de chegada a máscara à casa dos atuais tébés (nesse caso em dois lugares ligeiramente distantes na aldeia), a família começa a receber alimentos e bebidas de outras famílias, alguns trazidos por crianças, outros por idosos. Todas as carnes das caçadas (defumadas) já estavam há dois

Foto 57. Corrida dos pahâiri'wá. (foto Di Pannacci)

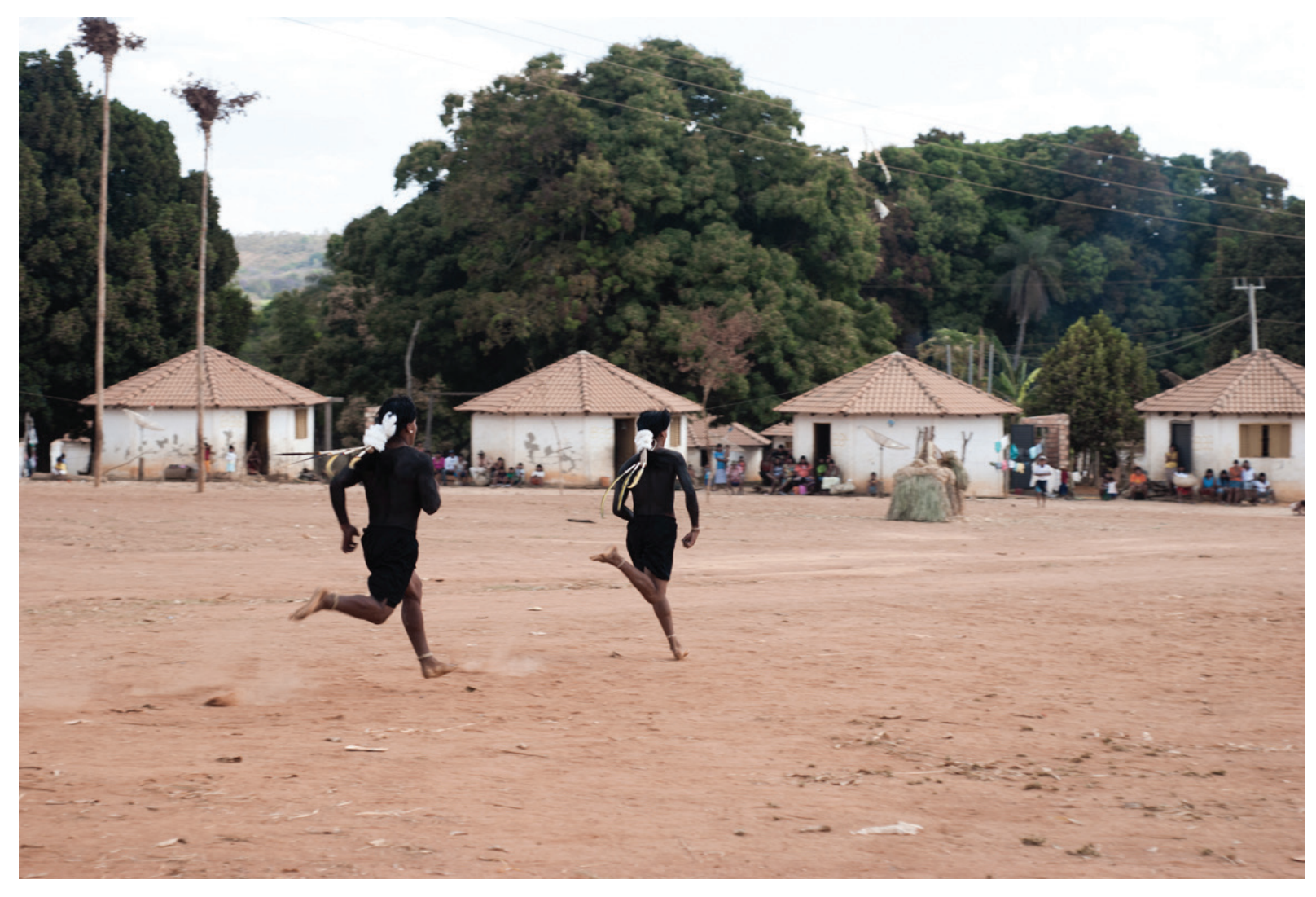


Heide que, como de praxe, também fazia filmagens chegou, em alguns momentos, a entrar na frente da câmera de Divino, o que o irritou bastante. É muito instigante notar o conflito entre um salesiano - que sempre fizera seus filmes sobre os rituais xavantes - com uma nova geração que, libertando-se das amarras da hetero-representação, passa a ela mesma se apresentar. Isso tudo ainda causa um enorme conflito na cabeça de Heide que, conforme ele mesmo depois me dissera, detesta a "poluição" de câmeras nas mãos dos xavantes "estragando" as cenas, sem perceber, diante de si, os muitos aspectos positivos que essa incrível mudança midiática propicia. Fato é que ele parece alimentar, em seu imaginário colonizador, a si próprio enquanto o único realizador de filmes sobre os xavantes (como uma espécie de chancela que julga que somente um salesiano poderia sê-lo) e, diante disso, entra na frente de qualquer outra câmera, ainda que estas sejam dos protagonistas da história, privilegiando uma pretensa "exclusividade" de seu ponto de vista.

Os novos tébés irão passar a noite assoviando para felicitar a aldeia e fazer com que os anciãos se recordem alegremente dos tempos passados. O noni, carregando com as costas, testa e mãos uma pesada máscara de folhas de buriti, seguirá madrugada adentro com eles, porém sem assoviar. Nós descansaremos até às 3:30 da manhã, para às 4 voltar à aldeia para registrar a bela jornada dos tébés e do noni ao amanhecer.

Voltamos à aldeia às 4 da manhã. Eu sentia muitas dores advindas de bolhas nos dedos dos pés formadas no árduo trabalho da noite anterior. Registramos o movimento dos tébés seguindo o noni pela aldeia e repetindo sempre o seguinte processo: chegam em frente a uma casa e param quando o noni se dirige a frente do semicírculo formado pelos waptés e os dois tébés passam a assoviar a melodia ensaiada enquanto levantam e abaixam as duas varinhas de palha, resvalando -as na máscara de buriti que carrega o noni. O processou durou até o amanhecer quando uma grande multidão se reuniu no centro da aldeia para assistir os antigos tébés retirarem as máscaras dos novos tébés.

Os antigos tébés passam então a bater uma grande muda de palmeira no chão, cada qual três vezes gritando ao final de cada batida. Depois os novos tébés e, depois ainda, os waptés, aos olhares atentos da comunidade que se divertia com os gritos desafinados e, tantas vezes, fracos e assustados dos jovens iniciantes.

No intervalo entre o tébé e os pahâiri'wá, Divino nos conduziu até a casa de sua irmã que cortou meu cabelo e de Rodrigo "a moda" xavante e depois nos dirigimos à casa de Fábio que nos pintou com o urucum. Durante esse processo foi interessante observar como a pintura e o corte de cabelo, ao gerarem um elemento de identificação, despertaram simpatia e aceitação em diferentes contextos na comunidade.

Depois de terminada a etapa do tébé, nosso corte de cabelo e pintura, voltamos à clareira para registrar o ensaio final dos pahâiri'wá para a dança do sol. Essa etapa é bastante emocionante. Assim como os tébés antigos (os tébés pertencem sempre ao clã Öwawe) que transmitem o conhecimento para os mais novos, os pahâiri 'wá antigos (os pahâiri'wá pertencem sempre ao clã Porizai'ono), também o fazem. Em duplas, com exceção do cacique Alexandre 


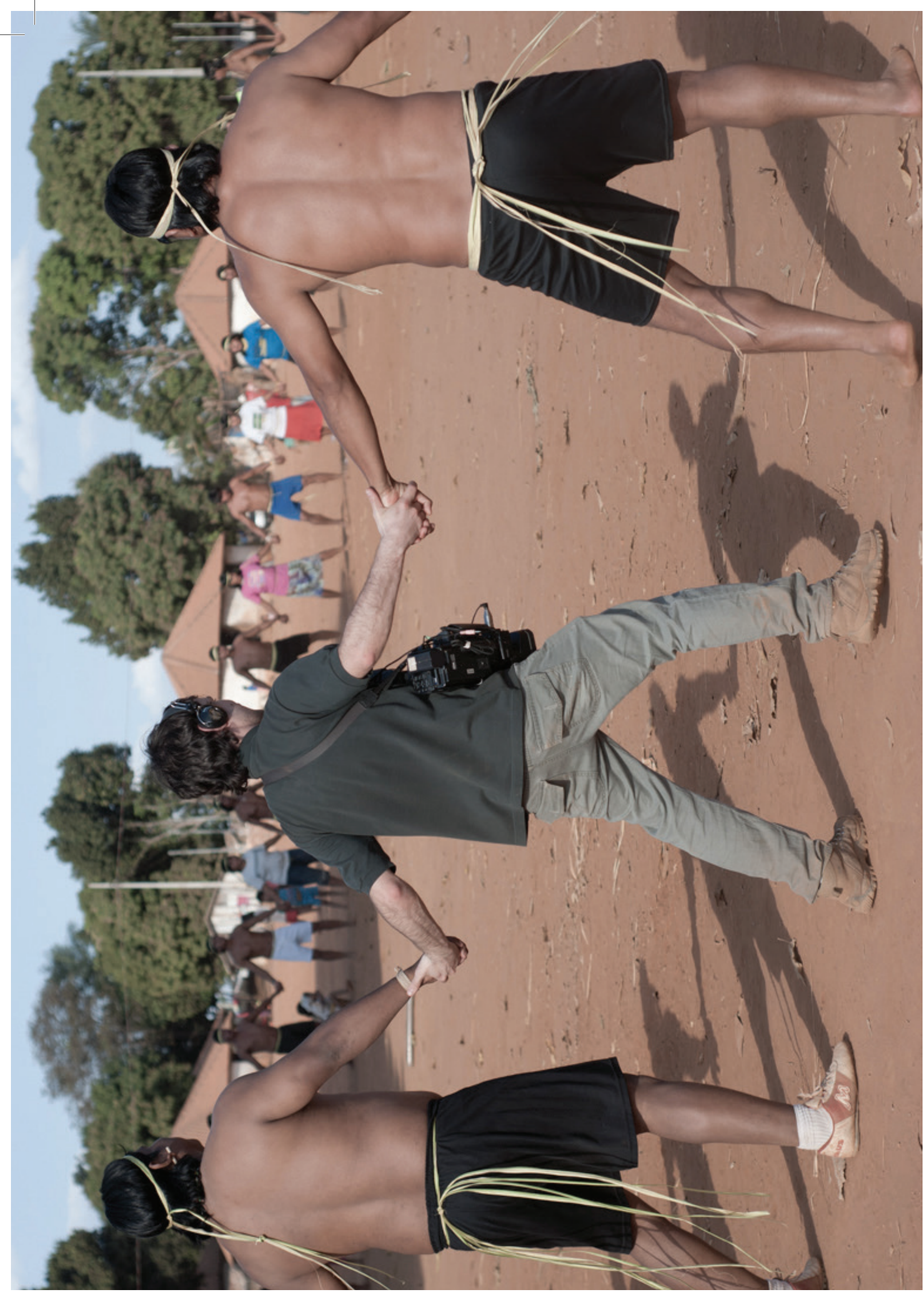

Foto 59. (da esq. para direita, de costas) Natal Anhahö'a, Caio Lazaneo e Eliseu Tserenhowamre, na dança dos

padrinhos Etepa. (foto: Di Pannacci) 


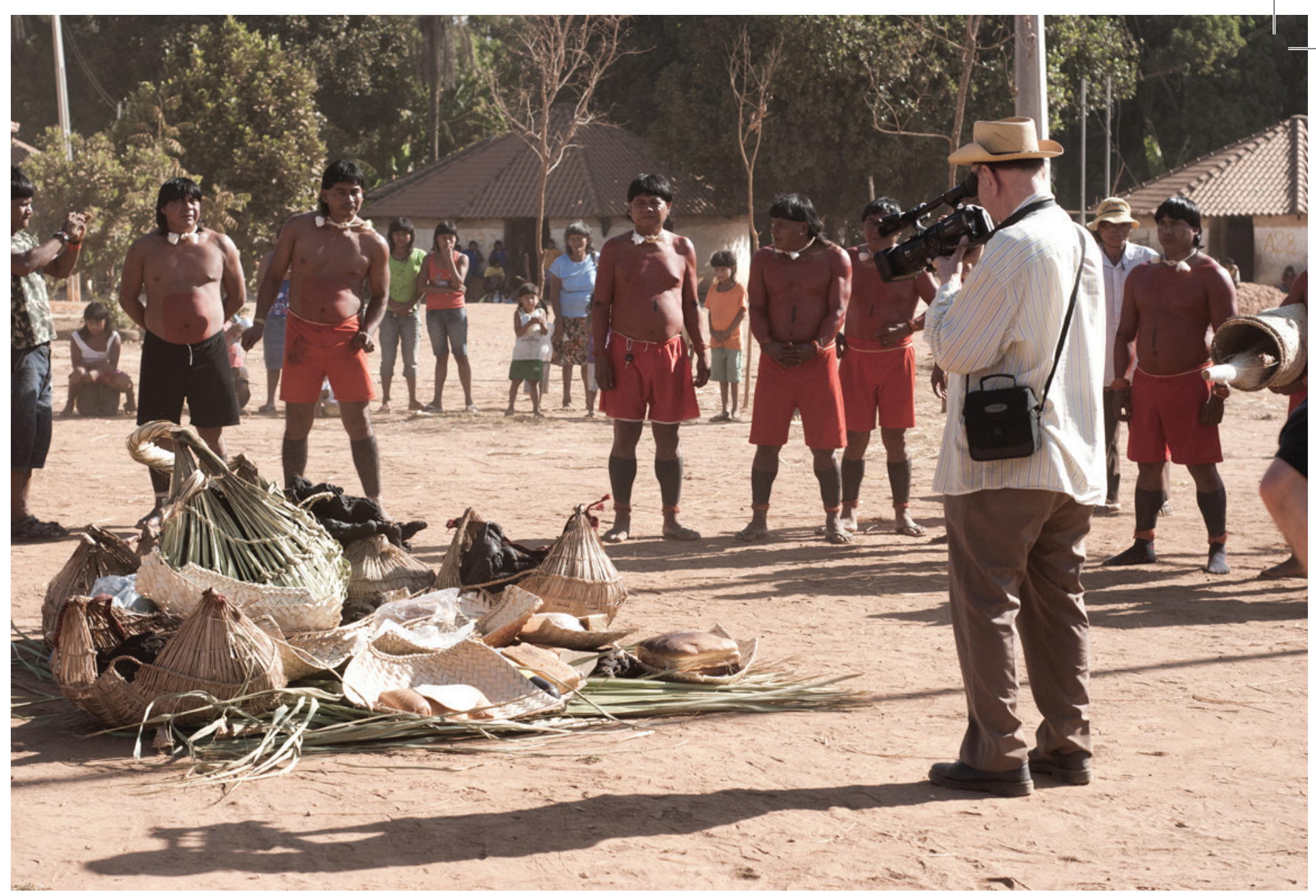

Foto 60. Adalbert Heide filma os baktés com alimentos (Foto: Di Pannacci)

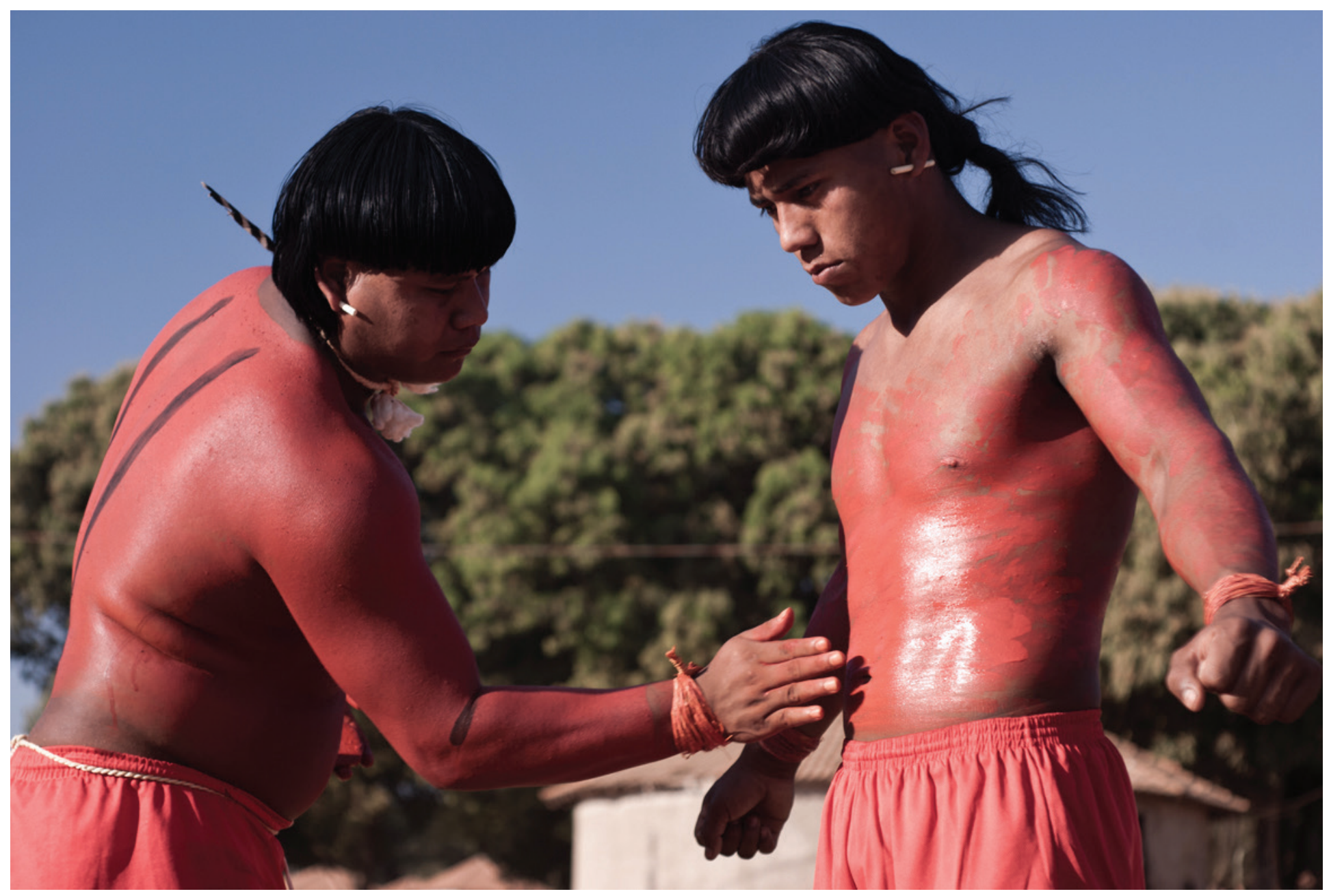




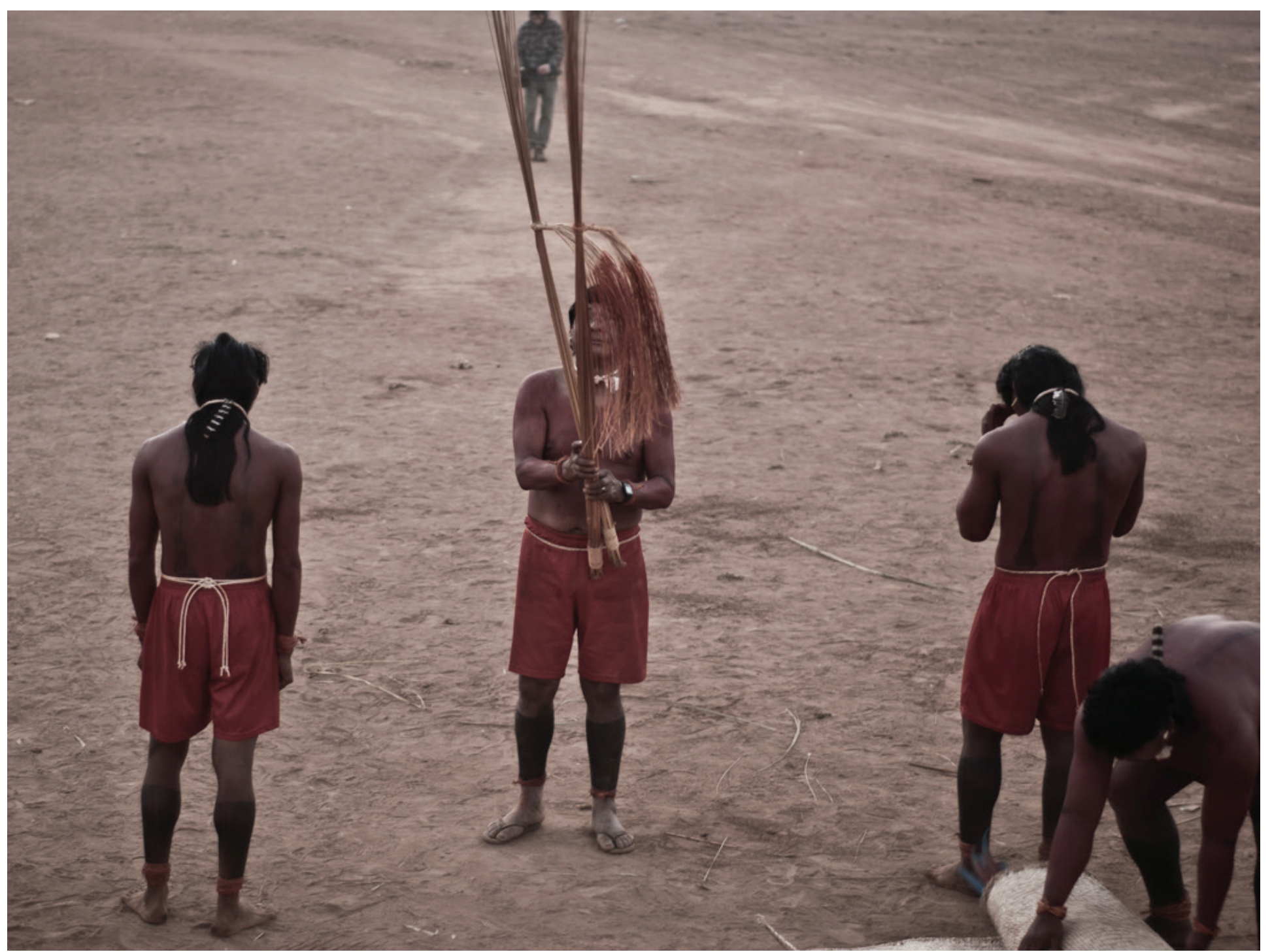

Foto 64. Tébés mais velhos terminam de retirar a máscara dos tébés mais novos (foto: Di Pannacci) 


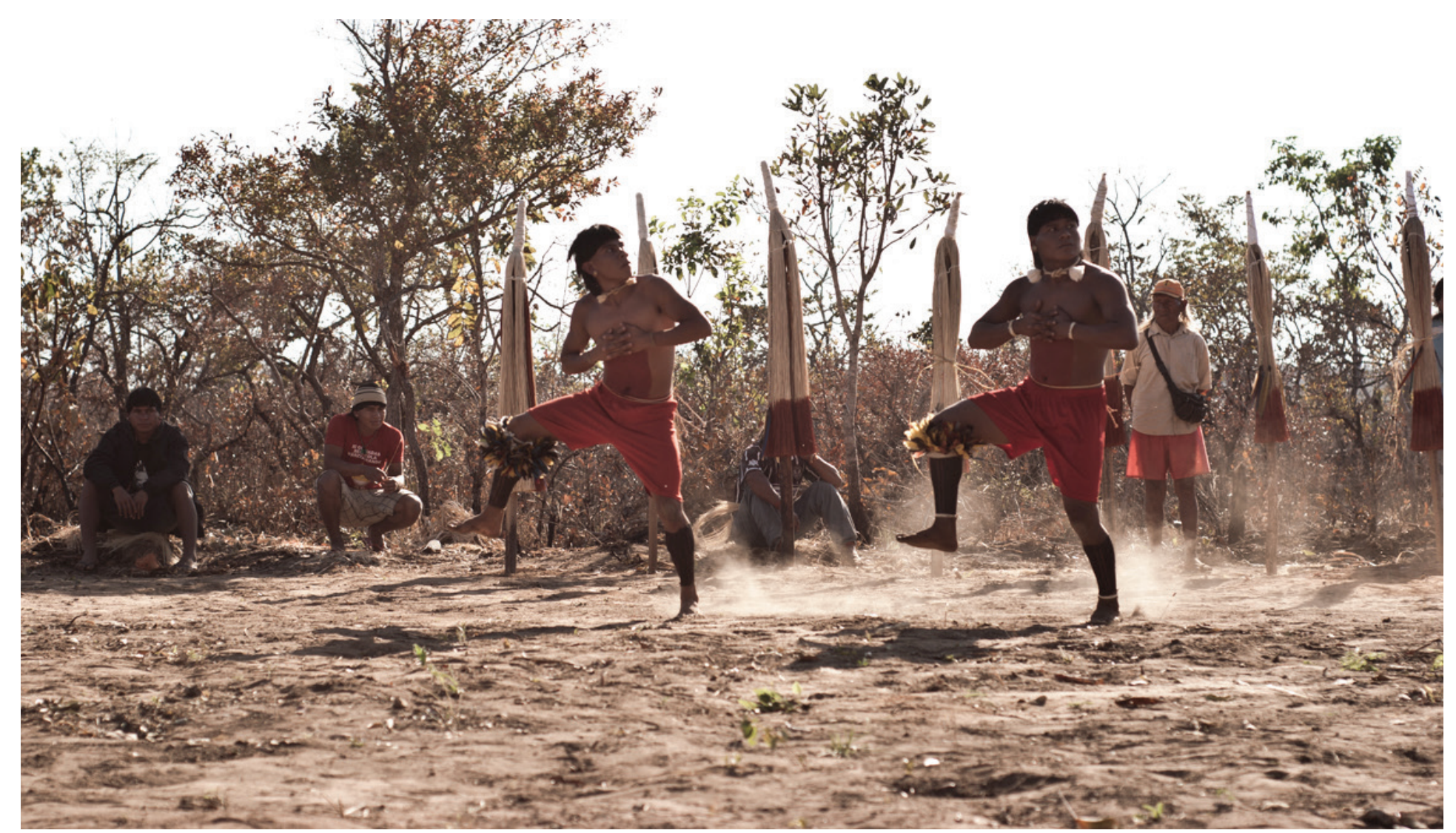

Foto 68. Os novos pahâiri'wá ensaiam a dança do sol (foto: Di Pannacci)

e que, de imediato, me permitiu uma reflexão sobre quantas vezes as mais diferentes pessoas e comunidades, na condição de objeto antropológico, não haviam assim se sentido. Depois disso, voltei a registrar o ritual e perto do amanhecer Divino, com o semblante bastante cansado, voltou para o centro da aldeia.

Tenho notado que o ritual do Wapté provoca em algumas pessoas (e com frequência as mesmas) uma espécie de euforia generalizada, principalmente entre os homens adultos, sendo comum as bebedeiras (o que não constitui, propriamente, uma interação com a festa). $\mathrm{O}$ rito de passagem torna ainda mais festivo o cotidiano de toda a comunidade, e por isso é compreensível que alguns tenham esse tipo de comportamento em um evento que acontece apenas a cada 7 anos.

Pela tarde, nos dirigimos para uma outra clareira, distante aproximadamente 8 quilômetros da aldeia, para filmar o ensaio do grupo Abare'u que deverá "atacar" os waptés Nozo' $h u$ durante a corrida final.

Divino logo cedo me chamou no alojamento da missão para iniciarmos a nova jornada, se mostrando bastante entusiasmado e com muito vigor nas filmagens que realizamos, afinal de contas se tratava da grande corrida dos waptés, o último dia do ritual. Nessa etapa, os waptés correm cerca de 8 quilômetros de uma clareira na mata até o centro da aldeia. Os abare'u, seus primeiros inimigos na sucessão das faixas etárias (já que foram os waptés da penúltima iniciação), fazem de tudo para atrapalhar a corrida dos mais jovens, inclusive neles jogando uma espécie de "veneno", feito a base de um pó da casca de uma árvore, que dizem causar 


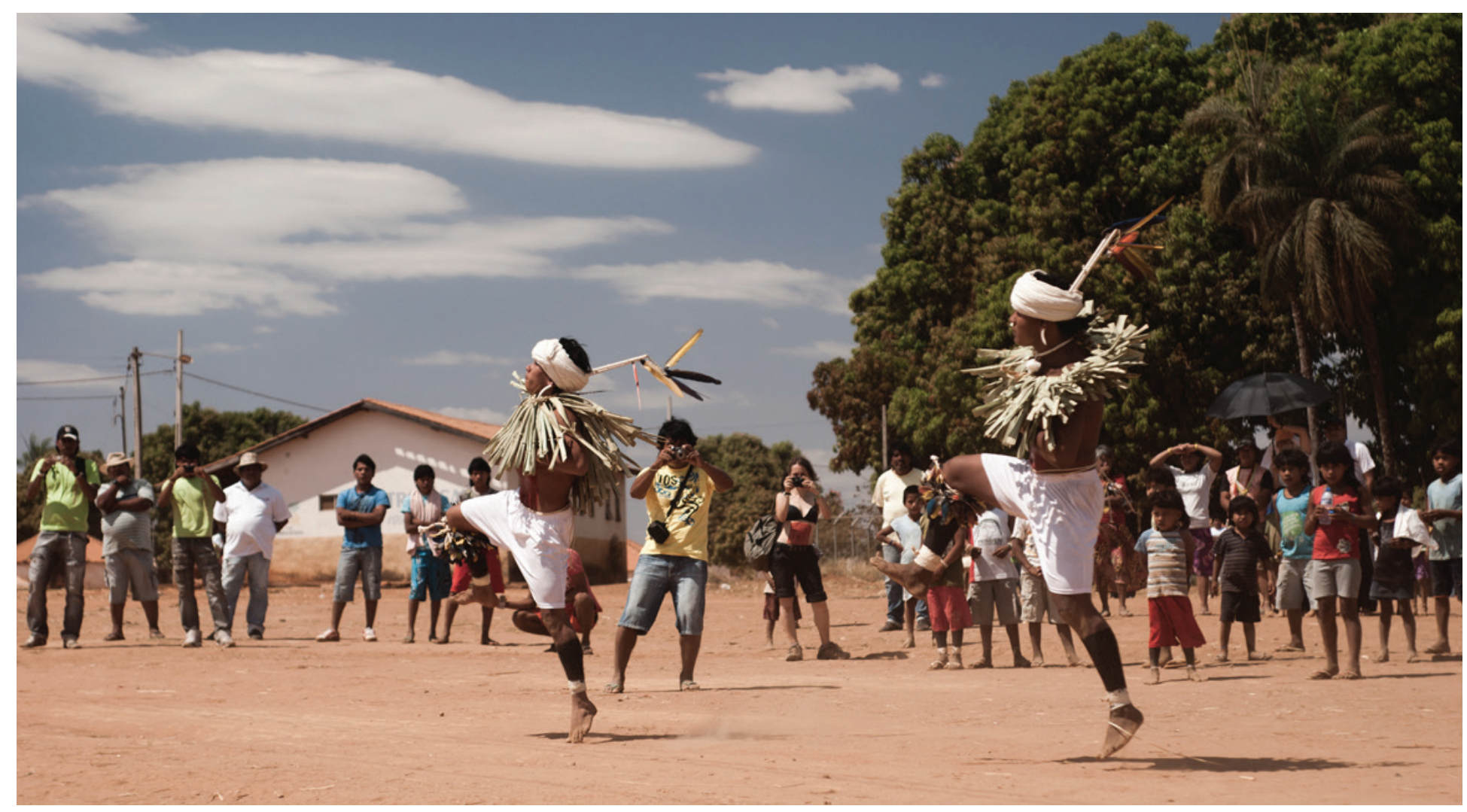

Foto 69. Os dois jovens pahâiri’wá fazem a dança do sol (foto: Di Pannacci)

desmaios nos iniciantes. No caminho também os etepas, padrinhos dos atuais waptés (já que são os antepenúltimos a terem sido iniciados, numa ordem de 8 subgrupos que se sucedem em forma de "rodízio". Quatro subgrupos consideram-se amigos, enquanto inimigos dos outros quatro, alternadamente, seguindo essa lógica sucessivamente) tem de protegê-los dos abare'u. Durante a corrida, registrei a partir da carroceria de uma caminhonete da Funai guiada por um funcionário xavante, os waptés (nozo'u), os abare'u, os padrinhos etepa, assim como idosos que supreendentemente também corriam apesar do fortíssimo calor e mulheres (mães, avós, tias) que, com os baktés carregadas na cabeça cheios de vasilhas de água, auxiliavam os corredores matando-lhes a sede. Ao final da corrida, que termina exatamente no centro da aldeia, um grande círculo se forma e os adultos e idosos, homens e mulheres, saúdam os novos adultos - que agora não são mais considerados waptés - passando a mão direita em suas cabeças. A corrida segue a lógica competitiva entre os grupos etários, gozando de prestígio o grupo vencedor. Segundo Natal me dissera, o grupo nozo'u havia vencido a corrida, o que eu não pude acompanhar já que não estava na linha de chegada. Pela tarde registrei o noivado simbólico que acontece num semicírculo de pequenas árvores (retiradas da mata e recolocadas no centro da aldeia) em que os jovens se deitam em esteiras e esperam que as mães das noivas (algo definido por acordos entre as famílias dos clãs opostos) as levem ao seu encontro. Quando a moça se deita na esteira, a mãe rapidamente a cobre com uma outra esteira, deixando o futuro casal encoberto por alguns segundos sob os olhos atentos de toda a comunidade que acompanha com grande entusiasmo o evento. Divino também estava muito entusiasmado e despertava risos dos xavantes quando simulava uma figura feminina ao deitar na esteira clamando por alguém, algo parecido que 
ele filmara no seu filme sobre o Wapté em que um adulto xavante brinca da mesma forma. Ao término da etapa, passei na casa de Divino, onde conversamos rapidamente sobre o trabalho. Ambos nos encontrávamos satisfeitos como o término da festa e podendo agora elucubrar sobre toda a dinâmica. Apesar de todas as dificuldades, todo o processo foi muito significativo e, pessoalmente, o meu envolvimento muito mais profundo. Divino algumas vezes me relatara a simpatia dos anciãos da comunidade (naturalmente os mais reconhecidos porta-vozes) para com nosso trabalho e também pela facilidade com que eu conseguia pronunciar as palavras no idioma a'uwé, além do corte de cabelo xavante que havíamos feito dois dias antes. Bartolomeu frequentes vezes me convidou a passar mais tempo na aldeia considerando, segundo ele, uma suposta facilidade que eu teria em aprender o idioma, assim como o acolhimento por parte de uma comunidade que já conhecia e participava efetivamente do trabalho partilhado.

Findo o ritual da metade de Divino, a outra recomeçou oficialmente seu ciclo e o final desta parte deverá acontecer ao final dessa semana que se inicia. Pela manhã ainda aconteceram algumas formalidades como a recolha das penas dos waptés pelos anciãos que as guardarão para poderem serem utilizadas na próxima iniciação.

Pela tarde, registrei um longo diálogo com o Padre Luís Leal. Com uma vivência de 25 anos entre os xavantes, o pároco coleciona histórias insólitas, em sua maioria divertidas, outras vezes tensas, as quais somente sujeitos com uma profundidade de vivência como a dele poderiam ter. É Interessante notar o prazer que ele tem na contação de suas histórias, algo que vínhamos notando duravnte as refeições que sempre se prolongavam em função da tecedura criada entre os causos, na qual uma questão que chamava atenção em uma era sempre o "ponto" que se ligava a uma nova, por vezes retomada na refeição seguinte. Houve dias em que a

Foto 70. Padrinhos correm para levar as máscaras às casas das famílias dos waptés. (foto: Di Pannacci)

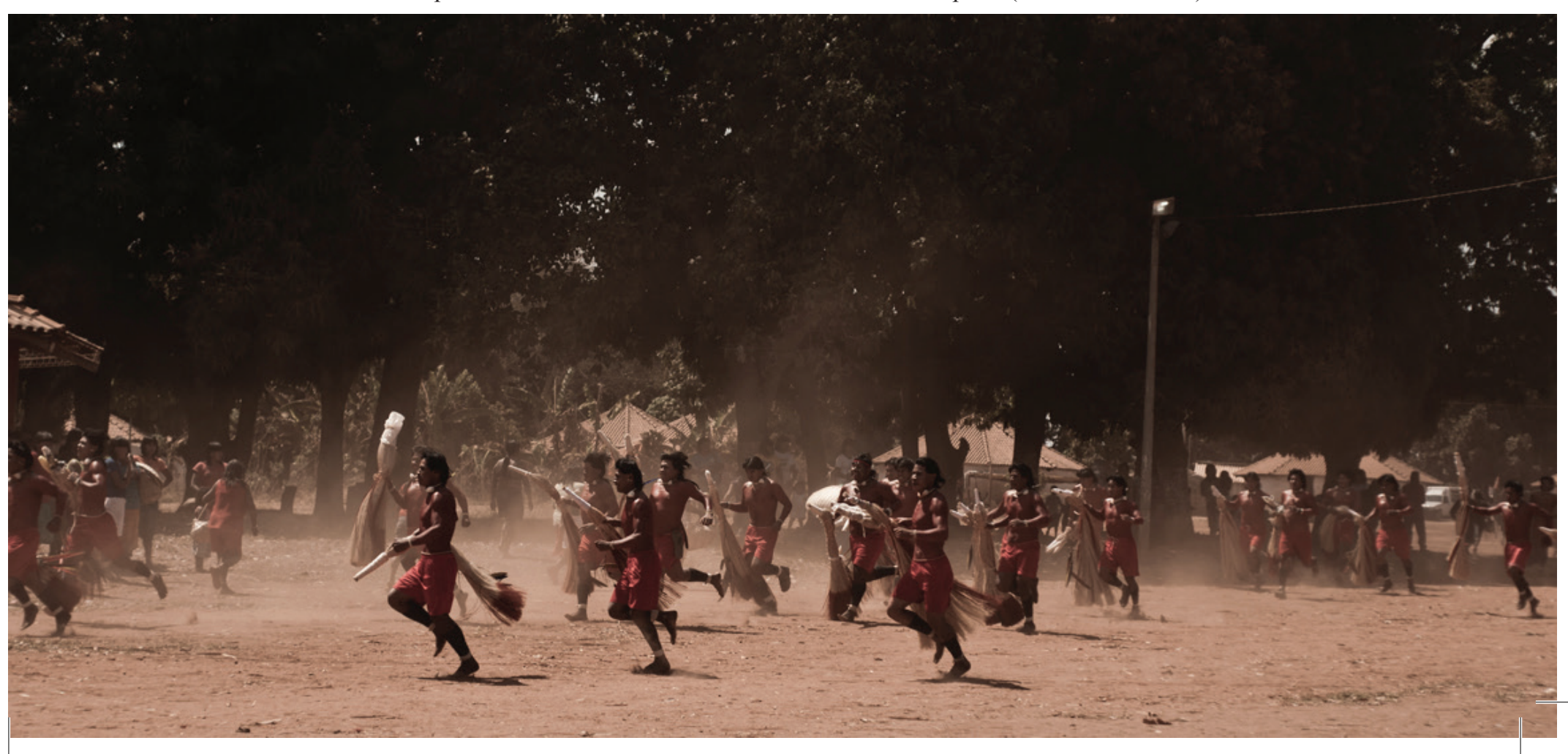


mesma história foi repetida mas, não obstante sua repetição, o Padre mantinha um vigor e humor tão peculiares que parecia como se contada fosse pela primeira vez. Já no fim da tarde pude registrar um diálogo, a meu ver, ainda mais interessante, do qual participaram dentro do museu o Padre Leal, Divino e Bartolomeu. Os três, assim como eu em alguns momentos, conversamos exaustivamente sobre aspectos da cultura xavante e respectivamente a leitura de cada um sobre esses fenômenos. No cotidiano nota-se um imenso respeito, ainda que não sejam raros os momentos em que surgem brincadeiras que carnavalizam a autoridade hierárquica, que os próprios xavantes (no caso Divino e Bartolomeu) nutrem pela dedicação do pároco à compreensão de sua cultura.

O momento mais interessante e, se é que assim pode-se chamar, sincrético, se deu num momento quando eu ainda estava com a câmera desligada. O Padre, supreendentemente, me dissera, "É que eu não costumo dizer isso por aí senão vão me tratar por herege, mas o gênesis xavante é, a meu ver, muito mais perfeito do que o gênesis cristão". Segundo seu raciocínio, o gênesis xavante seria geneticamente mais factível haja vista que em sua premissa não haveria um cruzamento consanguíneo, mas sim uma origem baseada no cruzamento de um homem com a mulher de seu clã oposto (logo, sem parentesco próximo) e de um outro homem com a mulher pertencente ao clã do primeiro (porizai'ono e öwawe), uma regra matrimonial mantida ainda hoje. Ainda em tom de leve troça dissera que, se possível fosse o gênesis cristão, o mundo estaria muito mais cheio de "retardados". Na minha leitura, este diálogo remete, de certo modo, às astúcias das "artes de fazer" de um sujeito em que, apesar de portador de um saber institucionalizado, hierárquico e advindo de um lugar próprio determinante, joga com as peças de seu cotidiano, no qual sugere uma nova proposição, não mais tão somente advinda de um discurso oficial cristão, mas fruto de um recurso híbrido e dialógico. Muito embora eu acredite que, se eu estivesse com o equipamento ligado, o dito não o teria sido.

Findo os dias de Wapté Mñoño, já no retorno para casa, reflito sobre que esta nova experiência parece ter me tornado, de certo modo, um wapté em trânsito. Como um ritual de passagem, algo que me coloca à prova de velhas certezas, depois de grandes desafios. 


\subsection{Partilha IV: Edição do filme Karajá na ECA - USP}

Após a gravação do ritual Hetohokã na aldeia Fontoura, no mês de março de 2011, passamos algum tempo buscando a viabilização de uma infraestrutura adequada para a montagem do material na Escola de Comunicações e Artes da USP, além do apoio para o transporte, hospedagem e alimentação dos três realizadores indígenas ${ }^{1}$ - Juanahú, Divino e Paulinho - que participaram das gravações. Em fevereiro de 2012, finalmente iniciamos os trabalhos de montagem com a vinda de Juanahú, Divino e Paulinho à Universidade de São Paulo (que lá ficaram de 12 à 16 de fevereiro de 2012).

Divino chegou por volta das duas tarde em São Paulo e nos encontramos no metrô Ana Rosa. Juanahú e Paulinho, vindos de outro destino, foram recebidos pela prof. Aivone que os levou ao hostel antes da chegada de Divino. Chegamos ao local, curiosamente chamado "Oca" (algo que me chamara a atenção quando estava buscando hospedagem para os três) e Divino imediatamente identificou artesanatos terena e nhambiquara nas paredes da recepção. Depois que Divino se acomodou, saímos para comer algo nas redondezas e acabamos encontrando Paulinho e Juanahú numa lanchonete. É sempre uma grata surpresa reencontrar amigos com quem tenho contato tão pouco frequente. Consigo me comunicar com Divino constantemente via rede, porém com Juanahú e Paulinho a comunicação é bem mais limitada. Eu não via Juanahú há quase um ano, desde a gravação do ritual que finalmente começaremos a montar. Já Paulinho, pude visitar em minha última estada em Sangradouro, quando aproveitei para ir à Meruri (sua aldeia). Depois da lanchonete, fomos ainda a uma padaria onde almoçamos e colocamos a conversa em dia. Juanahú nos contou sobre uma recente onda de suicídios entre jovens karajás, algo que o vem deixando bastante triste e preocupado. Lembrei-me de ter lido algo a respeito, em algum jornal, pouco antes de sua chegada. Fato é que a entrada desenfreada do álcool e, de acordo com Juanahú, de drogas, tem provocado um efeito devastador entre os karajás. Infelizmente o suicídio acontece, com alguma frequência, em outras etnias como os guarani kaiowá (neste caso também relacionado a perda das terras nos processos de demarcação). É interessante notar que Juanahú assume, em seu discurso, “um compromisso com seu povo", na perspectiva de que acredita que seu filme poderá contribuir para a diminuição dos suicídios, já que trata do ritual Hetohokã, fenômeno do cotidiano karajá em que a comunidade necessariamente deve manter-se unida e o filme, dirigido por alguém pertencente a ela, atribui ainda mais importância a esse contexto. Ao se verem e, segundo Juanahú, terem a lembrança de alguns dos jovens que participaram do último ritual (e que não mais lá estão), as famílias e a comunidade terão um alento e alegria ao compartilhar deste momento. É no Hetohokã, rito de 


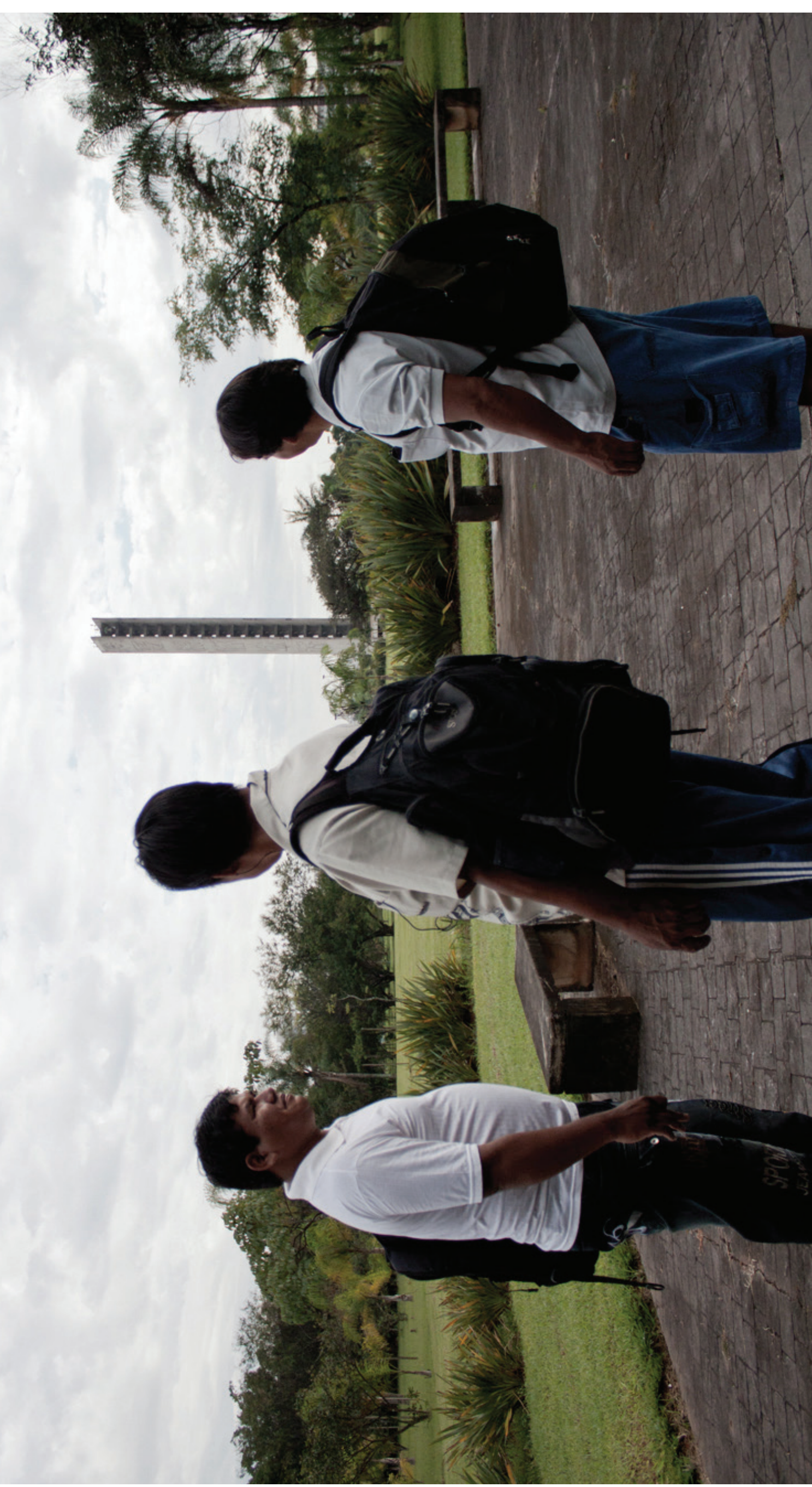

Foto 71. Novo tempo: Juanahú, Paulinho e Divino em frente a praça do relógio da Universidade de São Paulo. 
iniciação da vida adulta, que se reafirma o equilíbrio da sociedade karajá.

Depois do almoço retornamos ao "Oca", onde deixei os três descansando da longa viagem para na manhã seguinte iniciarmos os trabalhos.

Por volta das 8:30 da manhã, encontrei Divino, Paulinho, Juanahú e Aivone no metrô Ana Rosa. Não via Aivone há um ano, desde quando nos encontramos em Rondonópolis, antes da viagem minha e de Paulinho para o funeral bororo na aldeia Gomes Carneiro. O caminho até à USP, de metrô, inclui baldeação e, nesse horário, um fluxo muito grande de pessoas. Viemos, os cinco, espremidos no vagão. Eu e Aivone conversamos sobre a ideia do trabalho, enquanto Juanahú e Paulinho, menos habituados ao metrô, observavam o movimento incessante. Chegamos à USP, às 9:30 e, no caminho, Divino e Juanahú me falaram da vontade que tinham de estudar na universidade. Encontramos com o prof. Bairon que nos recebeu e nos levou até a nossa sala que funcionará como ilha de edição durante a semana.

O trabalho inicial consistiu em ensinar a Juanahú o processo de decupagem. Essa etapa será bastante difícil neste trabalho, já que temos filmado por volta de 30 horas e grande parte das entrevistas está na língua karajá, somente compreensível para Juanahú. Além disso, a estada deles em São Paulo será curta, de apenas 3 dias na ECA. Todo esse processo tem uma evidente importância na proposição, através do CEDIPP, da utilização do espaço (estrutura, equipamentos, pessoal, etc.) da universidade como agente na partilha do conhecimento com diferentes comunidades, e do retorno da experiência acadêmica, vivenciada pelo interlocutores, à essas comunidades. Nesse sentindo, essa é uma primeira e simbólica experiência. Durante o dia, alguns professores e funcionários do departamento passaram por nossa sala para serem apresentados, pelo prof. Bairon, ao grupo. Seguimos o dia decupando o material, permanecendo eu e Juanahú, numa máquina, selecionando cenas e trechos de entrevistas a serem utilizados, enquanto Divino e Paulinho capturavam o restante das fitas, em outra máquina, separando cenas boas e entrevistas na íntegra. Ao fim do dia, por volta das 22:30, tomamos um ônibus rumo ao metrô Butantã. No caminho, Juanahú e Divino alternaram na contação de piadas com personagens indígenas, invertendo a ridicularidade do protagonista alvo do riso, como ora sendo xavante (quando contado por Juanahú), ora sendo karajá (quando contado por Divino). A situação inusitada fez com que o cobrador do ônibus, próximo de onde estávamos sentados, não segurasse o riso. $\mathrm{O}$ teor das piadas, de modo geral, parece ter uma estrita relação com o universo que Bakhtin compreende, na obra de Rabelais, como pertencente ao riso ingênuo, positivo, valorativo. Uma espécie de riso que ri e celebra a vida (característica que sempre me chamou atenção principalmente entre os xavantes com quem convivi por mais tempo), oposto ao riso irônico.

Já no metrô, Divino tirou algumas fotos para celebrar o momento. Na estação Brigadeiro nos despedimos e eles seguiram para Ana Rosa. Amanhã retornaremos ao trabalho da decupagem, ainda não encerrado neste primeiro dia.

Nos encontramos, eu, Divino, Juanahú e Paulinho, no metrô Ana Rosa, às 8:00 da manhã e de lá seguimos para a USP. Na estação Butantã tomamos o ônibus circular que faz o trajeto até 


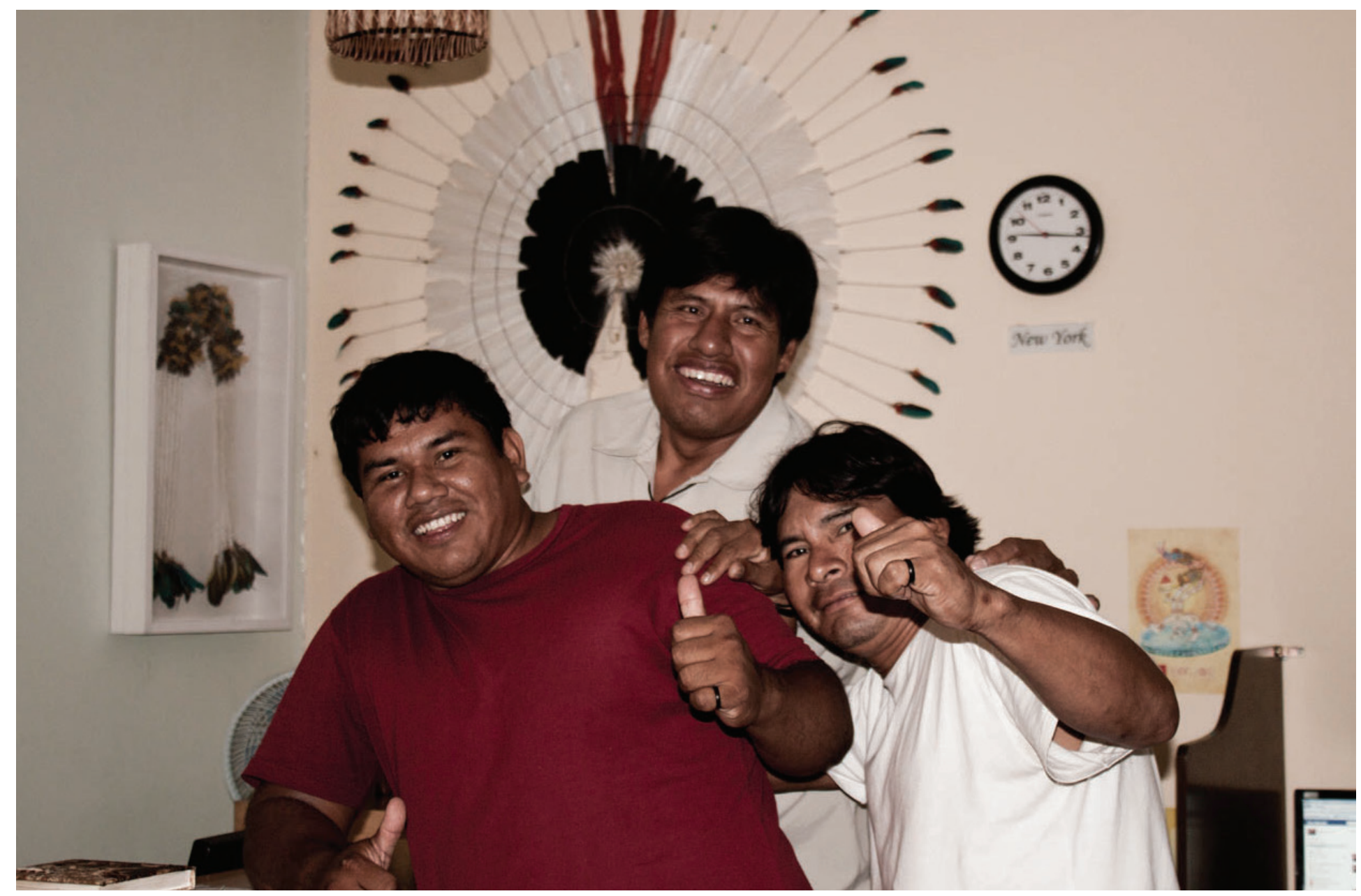

Foto 72. Juanahú, Paulinho e Divino na recepção do Oca hostel. (foto: Caio Lazaneo)

a Cidade Universitária. Dentro do campus, descemos próximo a Faculdade de Filosofia, Letras e Ciências Humanas (FFLCH).

Enquanto passávamos em frente aos prédios, persistia em meu pensamento uma reflexão sobre o ineditismo da situação por mim vivenciada. Neste encontro de interlocutores (de uma comunidade acadêmica e de comunidades indígenas), caminhávamos por espaços acadêmicos onde, por tantas vezes a relação universidade-comunidade - sobretudo com comunidades indígenas - e a produção de conhecimento fruto desse encontro, se dera de forma tão distanciada e objetiva. Resultando que, numa leitura crítica, o cartesianismo do método prevalecesse sobre um dialogismo do método. Não são raros os relatos, nas comunidades por onde passei durante a pesquisa in loco, sobre pesquisadores que lá estiveram, lá pesquisaram, e, por fim, para lá não retornaram, sequer, o produto acadêmico fruto de suas pesquisas. Evidentemente, um problema dialógico se instala na compreensão taxionômica de uma pesquisa acadêmica em relação às taxionomias cotidianas destas comunidades. Entretanto, somente essa questão não me parece suficiente para a justificativa da ausência do retorno, da negligência ao diálogo. Nesse caminho para nossa improvisada ilha de edição, refletia, ao mesmo tempo, sobre o quão interessante pode ser esse proposta de encontro e para todos os participantes do processo.

Pela manhã finalizamos a decupagem do material para, finalmente, iniciarmos a edição. 
Recebemos a visita da professora Aivone e da pequena Hyté - espontaneamente alegre e sempre curiosa com tudo o que vê e ouve -, e também do professor Sérgio Bairon, que registrou alguns de nossos diálogos durante o trabalho. A proposição de situações de reflexividade, e de registro das mesmas - a câmera enquanto espelho de espelhos - permeiam também as temáticas de pesquisa do CEDIPP.

No primeiro dia conseguimos produzir, efetivamente, um corte dos primeiros cinco minutos de filme, no qual pretendemos apresentar aspectos do contexto karajá (cenas da Ilha do Bananal, cenas de crianças que brincam, música off ritualística), como uma introdução harmoniosa ao filme tanto para inys (karajás) como para toris (não indígenas). As sequências são sempre determinadas no diálogo com Juanahú. Alternamos eu, Divino e Paulinho, operando o computador sempre com Juanahú ao lado, recebendo e fazendo sugestões. Ao fim do dia, por volta das 22:30, deixamos a USP, de ônibus, rumo à estação Butantã do metrô. Desta vez, ficamos no primeiro vagão, para que eu pudesse mostra-los o caminho do trem, que transita sem motorista, e que permite com se possa ver frontalmente, pela janela, o trajeto. Mais fotos para celebrar o momento. Juanahú aproveitou para sacar seu celular e gravar um vídeo onde ele, no idioma karajá, narrava a inventividade do meio de transporte assim como a companhia de seus

Foto 73. Juanahú e Paulinho decupam o material bruto do Hetohokã (foto: Caio Lazaneo)

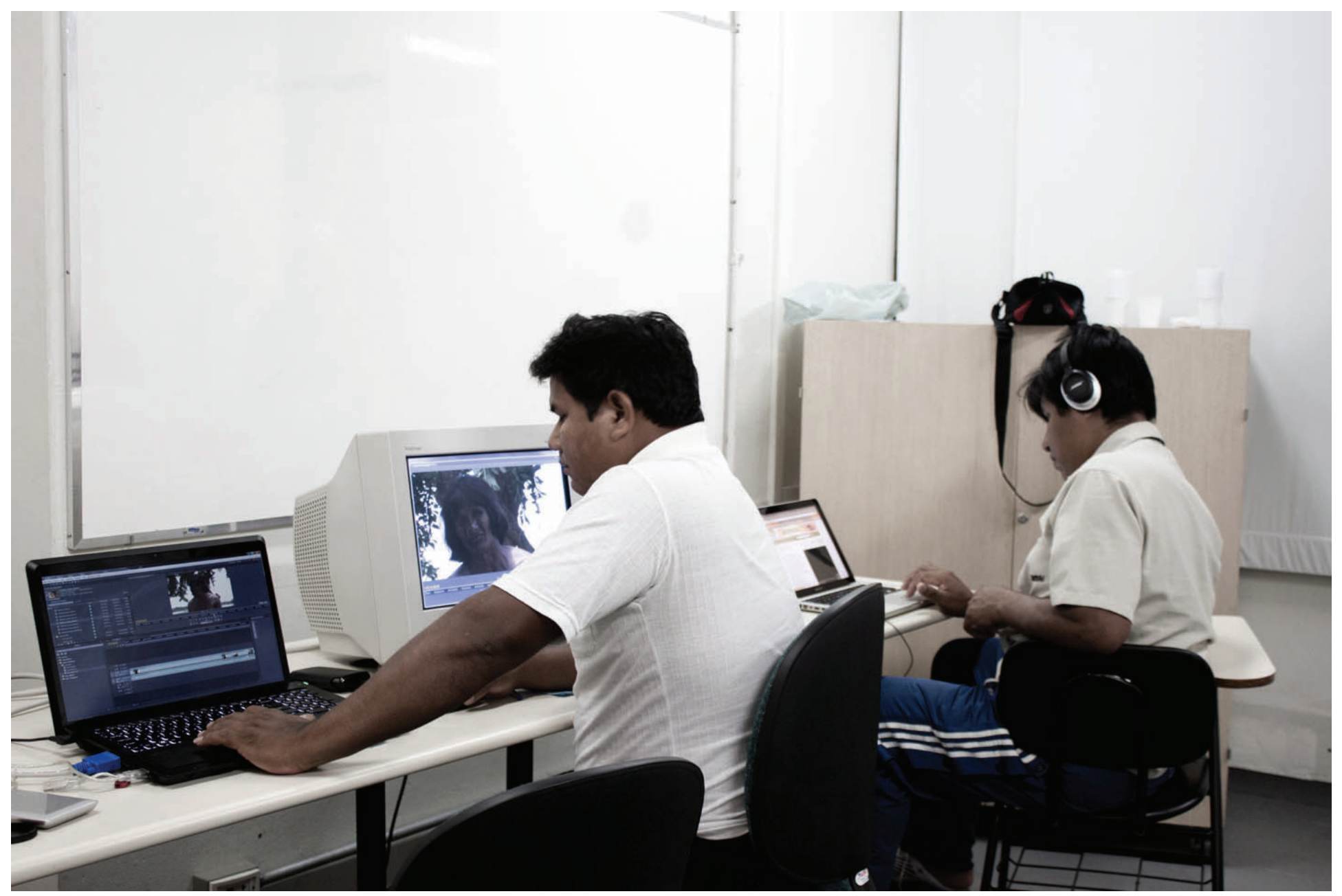




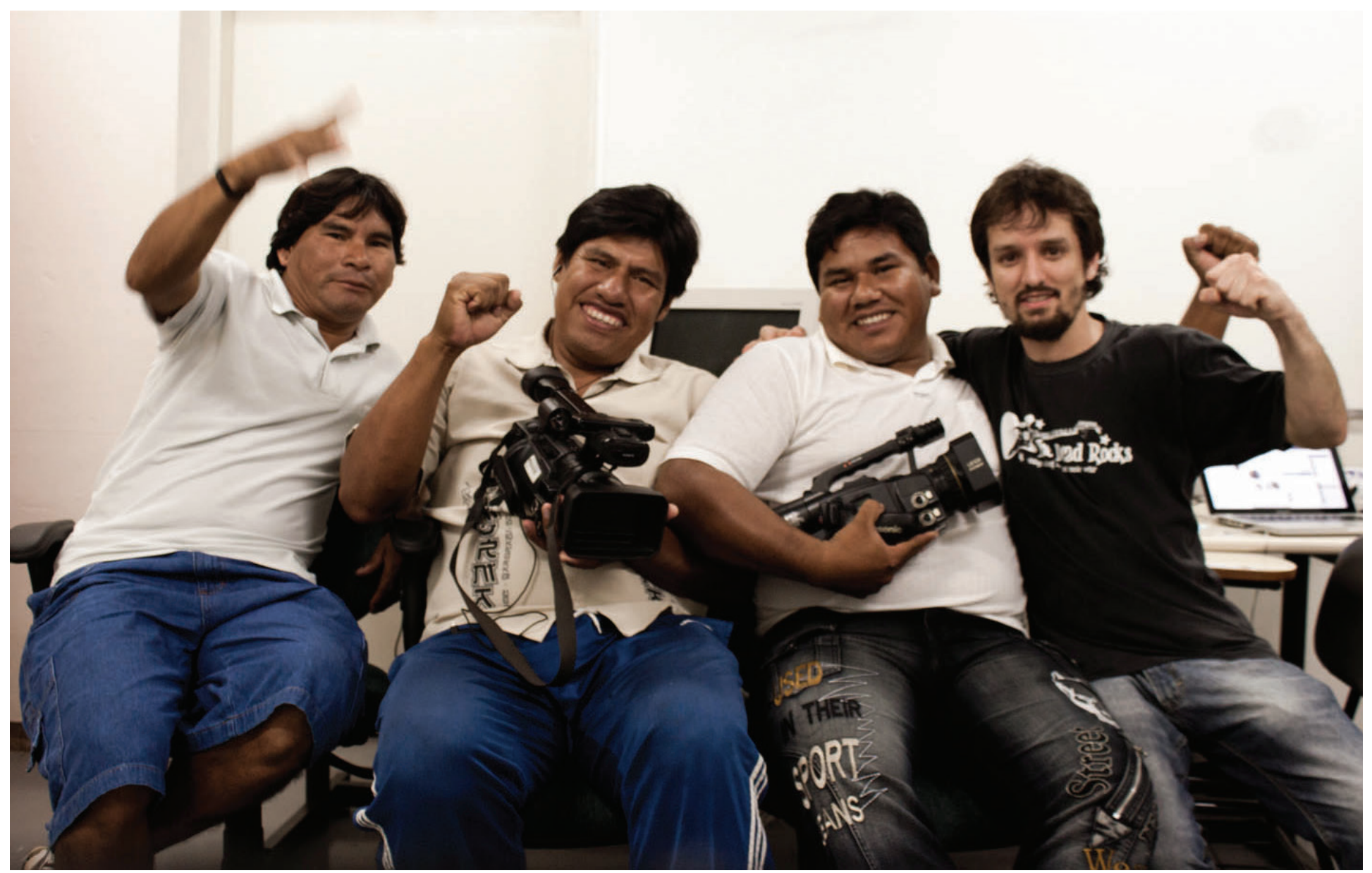

Foto 77. Divino Tserewahú, Paulinho Kadojeba, Juanahú Karajá e Caio Lazaneo na ECA-USP.

e almoçamos juntos. Pela tarde, uma triste notícia. Juanahú havia ligado para sua esposa que lhe informou sobre uma nova tentativa de suicídio de um jovem da aldeia Santa Isabel. O jovem havia tentado se enforcar, porém foi encontrado por parentes que o levaram ao hospital da cidade. A notícia deixou Juanahú visivelmente desmotivado. O cansaço acumulado do ritmo pesado de edição associado e esse novo fato fez com que o trabalho parasse de render. Fizemos assim uma pausa para que pudéssemos tomar um café e conversar. Já no fim da tarde, recebemos novas visitas. Primeiro de Angela Pappiani, da Ikorê, uma produtora cultural que mantém projetos muito interessantes como o portal "Programa de Índio". Ela já conhecia Divino e Paulinho e viera para conhecer Juanahú e contar-lhe que a famosa fotógrafa Claudia Andujar, gostaria de montar uma exposição conjunta das fotos que ela havia feito dos karajás da Ilha do Bananal (batidas há cinquenta anos) junto das fotos de algum fotógrafo karajá. Juanahú se empolgou muito com a ideia e prometeu enviar seu material para que ela analisasse assim que ele retornasse à aldeia. Angela aproveitou para gravar sonoras com os três para o "Programa de Índio" e eu filmei os diálogos. Mais tarde, nos visitaram Fernanda Silva, que faz uma interessante pesquisa de mestrado na Unifesp sobre os filmes de Divino, e Sérgio Domingues, professor da Unesp Marília. Durante os três dias de trabalho, as visitas foram frequentes e bastante enriquecedoras. Finalizamos o trabalho e retornamos de táxi ao "Oca", e de lá seguimos para um restaurante para comemorar a produtiva semana. 


\section{Considerações finais}

Há, em geral, na base da progressão intelectual própria à tradição ocidental, o que Flaubert chamava de 'a gana de querer concluir'. Essa foi a força da modernidade. Mas, agora que os encantos desse poder foram esgotados, não é mais inútil observar que o mundo, sua retórica e seus feitos são, essencialmente, plurais, não se prestam a uma conclusão mas sim a uma abertura. Numa palavra, conformam-se menos a uma representação, e isto no bom sentido do termo, do que a uma apresentação. Não devem, portanto, constituir objeto de uma demonstração, sejam quais forem as premissas, mas sim de uma mostração." (Maffesoli, 1998, p. 114)

\section{Uma trajetória do empírico ao conceitual}

Partindo de questões do cotidiano de distintas comunidades, pudemos elaborar uma trajetória, a princípio empírica, para um consequente desdobramento conceitual. Para tanto, foram necessárias articulações teórico-metodológicas que sustentassem, ao mesmo tempo, uma pesquisa acadêmica mas que, enquanto prática, não a distanciasse de seus interlocutores, objetivo este fundamental. Assim foram os dois anos e meio decorrentes do meu ingresso no mestrado em Ciências da Comunicação na Escola de Comunicações e Artes da Universidade de São Paulo. Um período que, felizmente, coincidiu com o momento inaugural e desenvolvimento de um grupo de pesquisa (para mim já tão especial) que fora o baluarte sob o qual pude depositar minhas incertezas e amplifica-las. Neste aspecto, o exercício da produção partilhada também se desenvolvera durante minha cotidianeidade acadêmica, em que este grupo - CEDIPP (que reúne não só pesquisadores como também interlocutores de comunidades) - sempre privilegiara temáticas - a mim tão caras e urgentes - como a produção do conhecimento em hipermídia, a experiência estética na produção do conhecimento, a produção partilhada, entre outras. Pude, desta forma, partilhar meus objetos e questionar própria noção de objeto, da departamentização do saber, das estruturas de poder institucionalizantes que incansavelmente afastam do cotidiano acadêmico o diálogo com o senso comum. Neste entorno, as trajetórias empírico-conceituais vão de encontro às diversas proposições, eixos temáticos e buscam alimentar diálogos.

Na presente pesquisa, buscamos assim empreender uma reflexão sobre a possibilidade interdisciplinar na produção de conhecimento (sobre a qual discorremos no primeiro capítulo). Analisamos, neste contexto, estratégias que iam do filme etnográfico à experiência hipermidiática, como suporte a uma discussão teórico-metodológica, na qual sublinhamos referencias disciplinares e interdisciplinares na produção do conhecimento. Reflexões que também enfrentamos naturalmente no trabalho de campo, sobretudo no diálogo com Divino, Juanahú e Paulinho que, a seu modo, guardam sempre consigo suas críticas a um modus operandi do saber científico que se apresenta, em larga escala, como absolutamente segregador 
e, ao mesmo tempo, sedutor.

Ao passo que, se tratando de um compromisso acadêmico, evidentemente procurávamos elaborar hipóteses de ordem científica para os problemas levantados, ao mesmo tempo estas hipóteses transbordavam seu pretenso lugar de origem, para se tornarem absolutamente importantes em um contexto que era não mais o da academia, mas de um senso comum, ou melhor, dos diferentes saberes locais. São fagulhas que cá deixamos e sobre as quais pretendemos voltar em breve.. Das dezenas, ou quiçá, centenas de pesquisas, teses e dissertações que foram produzidas acerca dos rituais de iniciação xavante e karajá, quantas efetivamente retornaram às suas comunidades, aos seus saberes de origem? Quantas das vozes destas comunidades que tantas vezes ofereceram o suporte necessário ao desenvolvimento destas pesquisas foram, em alguma oportunidade, convidadas a adentrarem no contexto acadêmico? Quais são as percepções das comunidades sobre estes trabalhos? Gostaria de presenciar meus amigos xavantes, bororos e karajás exercitando uma reflexão crítica audiovisual a respeito desta temática. Como Divino fizera em "Pi'õnhitsi: Mulheres xavantes sem nome" (2009), em que investiga as causas e polifonias de discursos em torno do não acontecimento de um ritual, ou como Paulinho, em seu “Boé Eru Kurireu: A grande tradição bororo” (2009), filme manifesto por uma ética da apresentação bororo ou, ainda, como Juanahú vem fazendo com seu filme sobre o ritual Hetohokã, em que enfatiza a importância de este ser, propriamente, o primeiro filme sobre este ritual feito a partir da direção de um karajá. Passamos deste modo pelas questões trabalhadas no segundo capítulo em que discutimos o cotidiano, senso comum e a hipermídia enquanto um entorno para a produção partilhada do conhecimento, um contexto no qual encontramos subsídios dialógicos que nos respaldam a uma crítica a um método científico em que pesa uma produtividade acadêmica, de lógica individualista. Consideramos que a hipermídia, enquanto um produto que pode articular diferentes níveis de compreensão (característica fundamental para uma partilha de conhecimento entre universidade e comunidade) e explorar a experiência estética como forma de produção de conhecimento, configura-se uma expressividade digital potencializadora do universidade-comunidade.

Por fim, apresentamos os diários de partilha em que os relatos e as fotos dos trabalhos de campo testemunham nossa trajetória empírico-conceitual e constituem os 4 principais vetores da presente pesquisa: 1. Curso de Formação de Cineastas Indígenas, Aldeia xavante Sangradouro 2. Registro do ritual Hetohokã karajá, Aldeia Fontoura. 3. Registro do ritual Wapté Mñoño, Aldeia xavante Sangradouro. 4. Edição no filme karajá, ECA - USP. Dentro destas quatro atividades, compreendemos as etapas metodológicas que buscamos propor para uma experiência de produção partilhada do conhecimento. 1. Aceitação e acolhimento por uma determinada comunidade 2. Partilha de saberes teóricos e técnicos, in loco, a partir de objetivos em comum. 3. Feedback conceitual: retorno e aprendizado sobre os saberes locais durante o trabalho in loco. 4. Feedback partilhado: convite aos interlocutores das comunidades à participação em atividades acadêmicas, no espaço acadêmico. 5. Devolução dos produtos audiovisuais e da pesquisa às comunidades. 
Entretanto, enquanto processo, ainda não fora possível (dentro dos prazos oficiais de conclusão da presente pesquisa de mestrado) o término dos produtos audiovisuais iniciados durante a trajetória de pesquisa (o filme de Juanahú sobre o ritual Hetohokã e o filme de Divino sobre o Wapté Mñoño) que, acima de tudo, poderão fundamentar ainda mais algumas de nossas hipóteses. Destarte, o processo e a partilha seguem, não só como uma premissa ética que implica, naturalmente, na devolução dos produtos às comunidades com as quais os trabalhos estão sendo realizados, bem como um horizonte epistemológico, absolutamente profícuo, sobre o qual desejamos aprofundar ainda mais as proposições de produção partilhada do conhecimento entre distintas comunidades e pesquisas acadêmicas. 


\section{Referências bibliográficas}

BAIRON, Sérgio. A hipermídia como comunicação integrada e a retomada da experiência estética na produção de conhecimento. Tese de livre docência. Universidade de São Paulo, 2007.

. "A comunicação nas esferas, a experiência estética e a hipermídia."

Revista USP, v. 86, p. 16-27, 2010.

Interdisciplinaridade. educação, história da cultura e hipermídia.. São

Paulo, Futura, 2002.

"Method, Hermeneutics and Hypermedia", in: Convenit - Selecta - 2 ISSN - 1517-6975, Harvard Low School - Cambridge - 2000. pp. 57-62.;

O que é Hipermídia. São Paulo, Brasiliense, 2011.

"Tendências da Linguagem Científica Contemporânea em Expressividade

Digital." Cibertextualidades, Potugal - Porto, v. 1, n. 1, p. 83-104, 2006.

BAIRON, Sérgio; TORRES, Rui . Produção do Conhecimento em meios digitais. Cibertextualidades (Porto), v. 3, p. 03-32, 2009

BAKHTIN, Mikhail. A Cultura Popular na Idade Média e no Renascimento: o contexto de François Rabelais. São Paulo: Hucitec, 1987.

. Estética da Criação Verbal. Tradução de Paulo Bezerra. São Paulo:

Martins Fontes: 2011.

Problemas da Obra de Dostoiévski. Rio de Janeiro: Forense, 1981.

BRANDÃO, Aivone C. O Museu na aldeia - Comunicação e transculturalismo no diálogo museu e aldeia. Campo Grande: UCDB, 2006

BURKE, Peter. Testemunha Ocular. Bauru, SP: EDUSC, 2005.

CANEVACCI, Massimo. A linha de pó: A cultura Bororo entre tradição, mutação e autorepresentação. São Paulo: Annablume, 2012. 
. Antropologia da Comunicação Visual. Rio de Janeiro, DPA. 1998

Comunicação Visual. São Paulo: Brasiliense, 2009.

Sincretismos: Uma exploração das hibridações culturais. São

Paulo: Studio Nobel: Instituto Cultural Italo Brasileiro - Istituto Italiano de Cultura, 1996.

DE CERTEAU, Michel. A invenção do cotidiano: 1. As artes de fazer. Petrópolis, Vozes, 2011.

DI FELICE, Massimo. Paisagens Pós-urbanas: O fim da experiência urbana e as formas comunicativas do habitar. São Paulo: Annablume, 2009.

FOSTER, Hal. The return of the Real. London, Cambridge, Mit Press, 1996.

GADAMER, Hans Georg. Verdade e Método I. Tradução de Flávio Paulo Meurer. 10. ed. Petrópolis, RJ: Vozes, 2008.

GEERTZ, Clifford. O saber local: novos ensaios em antropologia interpretativa. Tradução de Vera Mello Joscelyne. Petrópolis, Vozes, 1997, 366 pp.

HELLER, Agnes. O cotidiano e a história. Tradução de Carlos Nelson Coutinho e Leandro Konder. São Paulo: Paz e Terra, 2008.

KRAUSS, Rosalind. El inconsciente óptico. Madrid, Tecnos, 1999.

MEDINA, Cremilda \& GRECO, Milton (orgs.) Caminhos do Saber Plural - Novo Pacto da Ciência São Paulo: ECA-USP. 1999.

PEREIRA, Eliete da Silva. Ciborgues Indígen@s.br: Entre a atuação nativa no ciberespaço e as (re)elaborações étnicas indígenas digitais, disponível em: http://www.cencib.org/ simposioabciber/PDFs/CC/Eliete\%20Pereira.pdf . Acessado em 03/01/2011. 2007

PIAULT, Marc Henri. Anthropologie et cinema. Paris, Éditions Nathan/HER, 2000.

PINK, Sarah. The future of visual anthropology. New York, Routledge. 2006

RIBEIRO, José da Silva. “Antropologia Visual e Hipermídia” In: Ribeiro, José; Bairon, Sérgio. (Org.). Antropologia Visual e Hipermídia. Lisboa: Edições Afrtontamento,2007,pp.13-41. 
. Jean Rouch - Filme etnográfico e Antropologia Visual in Doc On-line, n.03, Dezembro 2007. disponível on-line em http://www.doc.ubi.pt/03/artigo_jose_ ribeiro.pdf, pp. 6-54. Acessado em 20/08/2010.

Homem da Câmera de Filmar: o cinema ou uma história do cotidiano? Revista Galáxia, São Paulo, n. 11, p. 37-55, jun. 2006.

- Notas para um debate em Antropologia Visual in Revista Mackenzie Educação, Arte e História da Cultura, ano 3/4, n. 3/4, 2003/2004, p. 45-67

SANTAELLA, Lucia. Matrizes da Linguagem e Pensamento: sonora, visual, verbal: aplicações na hipermídia. 3. ed. São Paulo: Iluminuras- FAPESP, 2005.

SATIKO, R.; SZTUTMAN, R.; ZEA, E.S. Conversas na desordem: Entrevista com Andrea Tonacci. Revista do IEB, no 45, set 2007. Disponível em: < http://www.revistasusp.sibi.usp.br/ pdf/rieb/n45/a14n45.pdf>. Acessado em: 05/04/2011.

SATO, Sérgio. 2009. A tensão Dialógica entre auto e heterorrepresentação no funeral Bororo na Terra Indígena de Meruri. 2009. 202 f.. Dissertação (Mestrado em Comunicação e Semiótica) - Pontifícia Universidade Católica, São Paulo. 2009.

SHOHAT, Ella e STAM, Robert. Crítica da imagem eurocêntrica: Multiculturalismo e Representação. São Paulo: Cosac Naify, 2006.

LÈVI-STRAUSS, Claude. Tristes Trópicos. Lisboa: Edições 70, 1986.

TACCA, Fernando. "Rituaes e festas Bororo: a construção da imagem do índio como" selvagem" na Comissão Rondon" Revista de Antropologia, vol.45, no.1, São Paulo, 2002. Disponível em: $<\mathrm{http} / / / \mathrm{www}$.scielo.br/scielo.php?script=sci_pdf\&pid=S003477012002000100006\&lng=en\&nrm=iso\&tlng=pt $>$. Acessado em: 05/12/2010.

Filmes:

BOÉ Eru Kurireu (A Grande Tradição Bororo). Direção de Paulinho Ecerae Kadojeba. 2009. 
CRÔNICA de um Verão. [Filme-vídeo]. Direção de Jean Rouch e Edgar Morin. 1960. DVD (90 $\mathrm{min})$, pb, som.

HOMEM da câmera de filmar, o. Direção de Dziga Vertov. 1929. DVD (68 min.), pb. som.

INDÍGENAS digitais, o filme. Direção de Sebatian Gerlic. 2010. Digital (26 min), color., som. disponível em < http://www.vimeo.com/11283052 >, Acessado em: 15/03/2011.

JEAN Rouch, Subvertendo Fronteiras. Direção de Ana Lucia Ferraz, Edgar T. da Cunha, Paula Morgado e Renato Sztutman. 1999. DVD (42 min), color., som.

PIÕ’NHITSI, Mulheres xavantes sem nome. Direção de Divino Tserewahú. 2009. DVD (56 min.), color., som.

RITUAES e Festas Bororo. Direção de Major Luiz Thomaz Reis.1916. DVD (26 min), pb. mudo.

SERRAS da Desordem. Direção de Andrea Tonacci. 2006. DVD (135 min), color., som.

TSÖ'REHIPÃRI (Sangradouro). Direção de Divino Tserewahú, Tiago Campos Tôrres e Amandine Goisbault. 2009b. DVD (28 min.), color., som. 